\title{
Evaluation of Surface-Water/Ground-Water Interactions in the Santa Clara River Valley, Ventura County, California
}

Water-Resources Investigations Report 98-4208

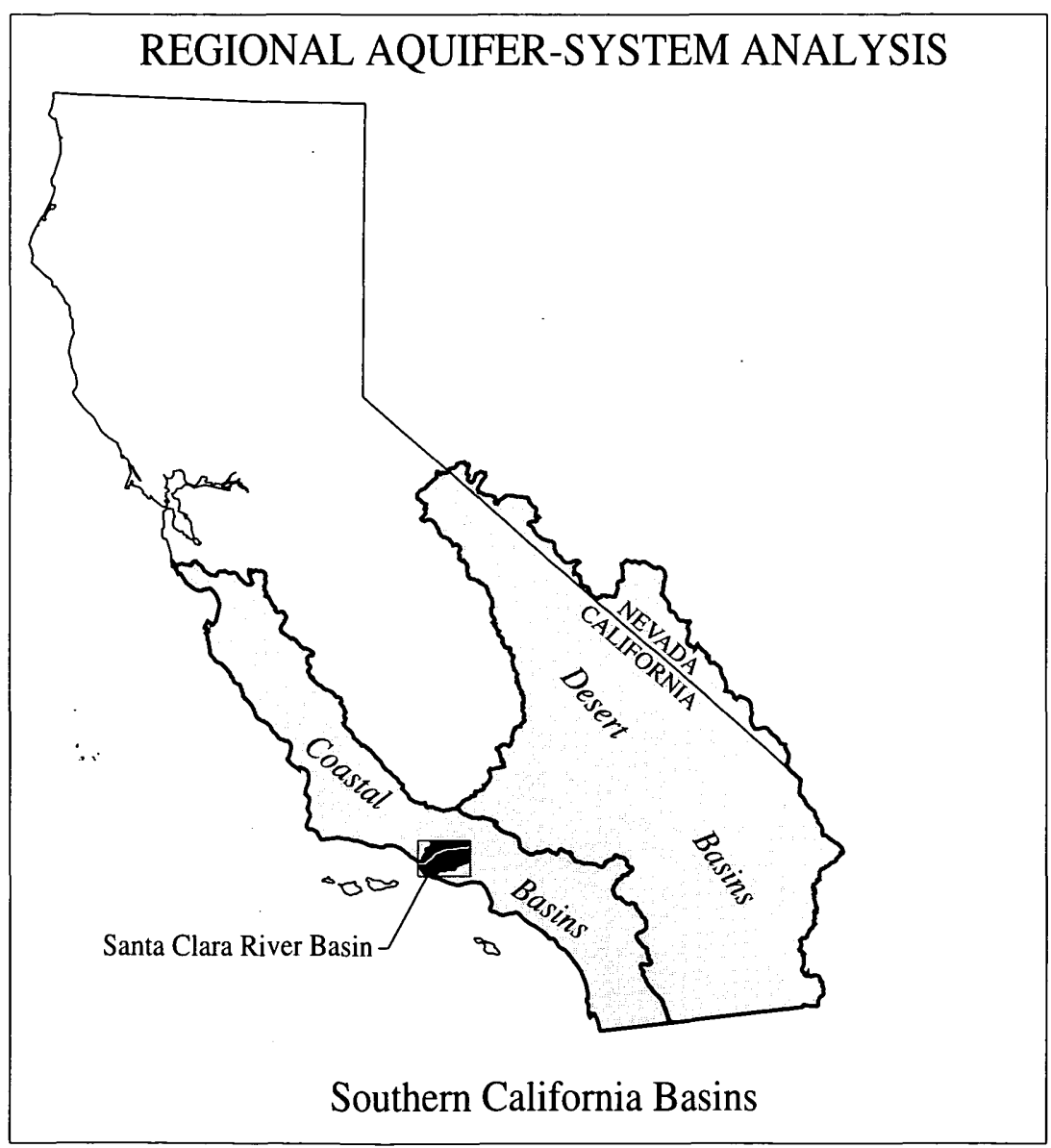

Prepared in cooperation with the UNITED WATER CONSERVATION DISTRICT






\section{Evaluation of Surface-Water/Ground-Water Interactions in the Santa Clara River Valley, Ventura County, California}

By Eric G. Reichard, Steven M. Crawford, Katherine Schipke Paybins, Peter Martin, Michael Land, and Tracy Nishikawa

\section{U.S. GEOLOGICAL SURVEY}

Water-Resources Investigations Report 98-4208

Prepared in cooperation with the

UNITED WATER CONSERVATION DISTRICT

홈 


\title{
U.S. DEPARTMENT OF THE INTERIOR \\ BRUCE BABBITT, Secretary
}

\author{
U.S. GEOLOGICAL SURVEY \\ Charles G. Groat, Director
}

The use of firm, trade, and brand names in this report is for identification purposes only and does not constitute endorsement by the U.S. Geological Survey.

For additional information write to:

District Chief

U.S. Geological Survey

Placer Hall, Suite 2012

6000 J Street

Sacramento, CA 95819-6129
Copies of this report can be purchased from:

U.S. Geological Survey Information Services

Box 25286

Federal Center

Denver, CO 80225 


\section{CONTENTS}

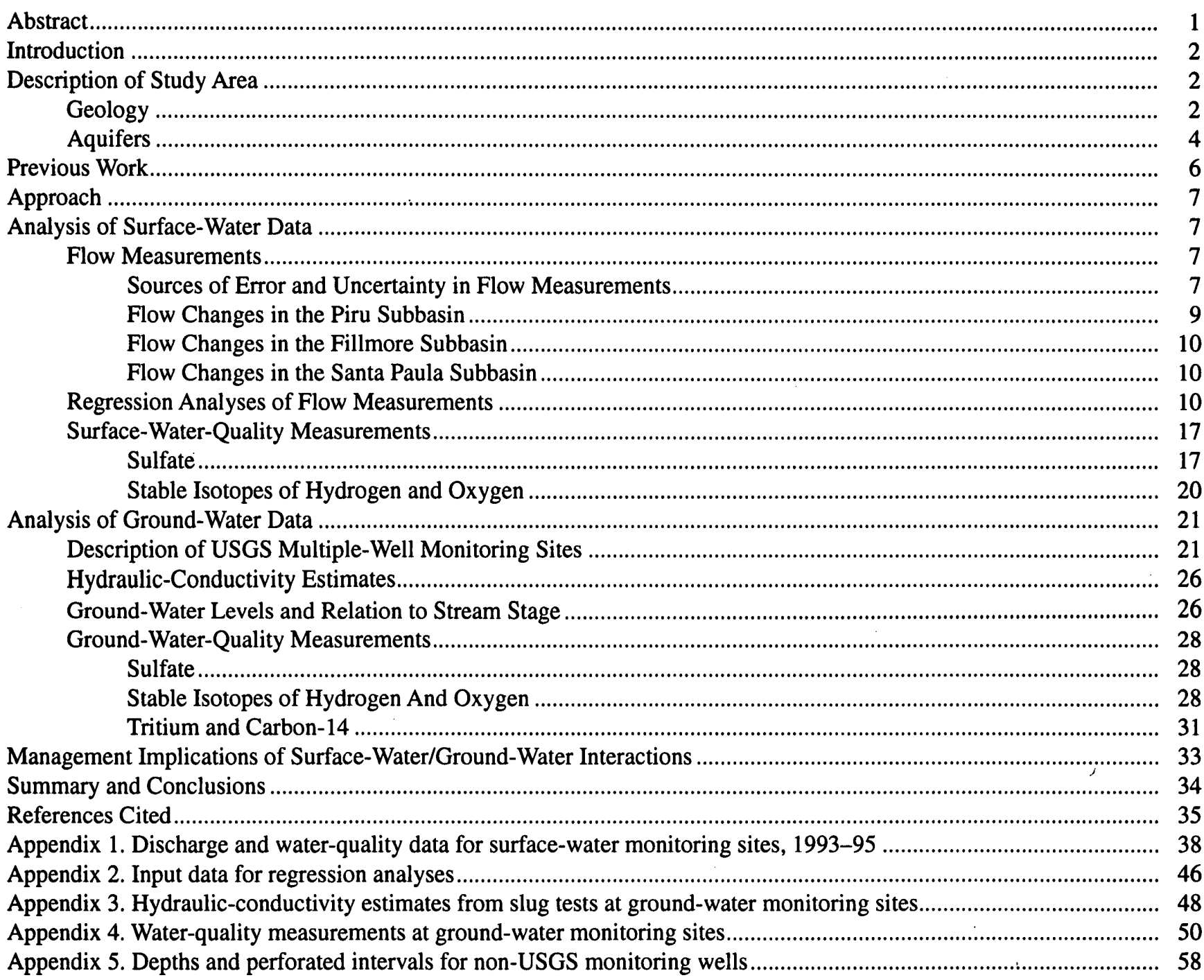

\section{FIGURES}

1. Map showing surface-water and ground-water sampling sites in the study area, Santa Clara River basin, Ventura County, California

2. Generalized geohydrologic section through the Santa Clara River basin, Ventura County, California ...

3. Graph showing discharge measurements and sulfate concentrations at surface-water monitoring sites in the Santa Clara River basin, Ventura County, California, for selected periods during 1993-95 50 58

4. Grpah showing net flow loss in the Piru, Fillmore, and Santa Paula subbasins, Santa Clara River basin, Ventura County, California..

5. Hydrographs for selected wells, observed-precipitation and calculated-cumulative-departure curves for precipitation stations at Santa Paula and Port Hueneme, Santa Clara River basin, Ventura County, California ..... 
6-10. Graphs showing:

6. Net flow loss in Piru Creek and the Santa Clara River in the Piru, Fillmore, and Santa Paula subbasins as a function of release from Lake Piru and as a function of depth to ground water, Santa Clara River basin, Ventura County, California

7. Flow in the Santa Clara River upstream from the Freeman Diversion (site 22) as a function of release from Lake Piru, and as a function of depth to ground water at well 4N/18W-29M2, Santa Clara River basin, Ventura County, California...

8. Sulfate and chloride concentrations and flow rate at the Freeman Diversion (site22), 1993-97, Santa Clara

River basin, Ventura County, California

9. Delta deuterium composition at surface-water monitoring sites in the Santa Clara River basin, Ventura County, California, for selected periods during 1993-95.

10. Delta deuterium as function of delta oxygen-18 in surface water, Santa Clara River basin, Ventura County, California

11-13. Geophysical logs, lithologic description, and well-construction diagram for multiple-well monitoring sites in the Santa Clara River basin, Ventura County, California:

11. Site SP1 (wells 3N/21W-15G1,2,3,4,5)

12. Site SP2 (wells $3 \mathrm{~N} / 21 \mathrm{~W}-16 \mathrm{H} 5,6,7,8$ ).

13. Site RP1 (wells $4 \mathrm{~N} / 18 \mathrm{~W}-31 \mathrm{D} 3,4,5,6,7$ )

14. Graphs showing water level in drive points in the Santa Clara River and in monitoring wells at sites SP1, SP2, and RP1, 1994-96, Santa Clara River basin, Ventura County, California.

15. Map showing sulfate concentrations, Santa Clara River basin, Ventura County, California

16. Map showing delta deuterium and delta oxygen-18 values in samples from selected wells, Santa Clara River basin, Ventura County, California.

17. Graph showing delta deuterium as a function of delta oxygen-18 in water from wells, Santa Clara River basin, Ventura County, California .

18. Map showing tritium and carbon-14 values in samples from selected wells, Santa Clara River basin, Ventura County, California.

\section{TABLES}

1. Lithologic units and aquifers in the study area ................................................................................................

2. Releases from Lake Piru and diversions at Piru spreading grounds during data-collection periods ...................... 9

3. Results of regression analyses

CONVERSION FACTORS, ABBREVIATIONS, WATER-QUALITY INFORMATION, VERTICAL DATUM, AND WELL-NUMBERING SYSTEM

\begin{tabular}{rcl}
\hline Multiply & By & To obtain \\
\hline & Length & \\
\hline inch (in.) & 25.4 & millimeter \\
foot (ft) & 0.3048 & meter \\
mile (mi) & 1.609 & kilometer \\
\hline & Area & \\
\hline square mile $\left(\mathrm{mi}^{2}\right)$ & 259.0 & hectare \\
square mile $\left(\mathrm{mi}^{2}\right)$ & 2.590 & square kilometer \\
\hline & Flow rate & \\
\hline acre-foot per year (acre-ft/yr) & 1,233 & cubic meter per year \\
acre-foot per year (acre-ft/yr) & 0.001233 & cubic hectometer per year \\
cubic foot per second $\left(\mathrm{ft}{ }^{3} / \mathrm{s}\right)$ & 0.02832 & cubic meter per second \\
\hline & Hydraulic conductivity & \\
\hline foot per day $(\mathrm{ft} / \mathrm{d})$ & 0.3048 & meter per day \\
\hline
\end{tabular}

Temperature in degrees Celsius $\left({ }^{\circ} \mathrm{C}\right)$ may be converted to degrees Fahrenheit $\left({ }^{\circ} \mathrm{F}\right)$ as follows:

$$
{ }^{\circ} \mathrm{F}=\left(1.8 \times{ }^{\circ} \mathrm{C}\right)+32
$$




\section{Abbreviations:}

GIS

PVC

Geographic information system

RASA Polyvinyl chloride

TU Regional Aquifer-System Analysis

USGS Tritium unit U.S. Geological Survey

UWCD United Water Conservation District

\section{Water-Quality Information}

Specific conductance is given in microsiemens per centimeter at 25 degrees Calsius $\left(\mu \mathrm{S} / \mathrm{cm}\right.$ at $\left.25^{\circ} \mathrm{C}\right)$. Concentrations of chemical constituents in water are given in milligrams per liter $(\mathrm{mg} / \mathrm{L})$ or micrograms per liter $(\mu \mathrm{g} / \mathrm{L})$

\section{Vertical Datum}

Sea level: In this report, "sea level" refers to the National Geodetic Vertical Datum of 1929 (NGVD of 1929)-a geodetic datum derived from a general adjustment of the first-order level nets of both the United States and Canada, formerly called Sea Level Datum of 1929.

\section{Well-Numbering System}

Wells are identified and numbered according to their location in the rectangular system for the subdivision of public lands. Identification consists of the township number, north or south; the range number, east or west; and the section number. Each section is divided into sixteen 40-acre tracts lettered consecutively (except I and $O$ ), beginning with " $\mathrm{A}$ " in the northeast corner of the section and progressing in a sinusoidal manner to " $\mathrm{R}$ " in the southeast corner. Within the 40 -acre tract, wells are sequentially numbered in the order they are inventoried. The final letter refers to the base line and meridian. In California, there are three base lines and meridians; Humboldt $(\mathrm{H})$, Mount Diablo (M), and San Bernardino (S). All wells in the study area are referenced to the San Bernardino base line and meridian (S) Well numbers consist of 15 characters and follow the format 004N020W26L001S. In this report, well numbers are abbreviated and written $4 \mathrm{~N} / 20 \mathrm{~W}-26 \mathrm{~L} 1$. The following diagram shows how the number for well $4 \mathrm{~N} / 20 \mathrm{~W}-26 \mathrm{~L} 1$ is derived.

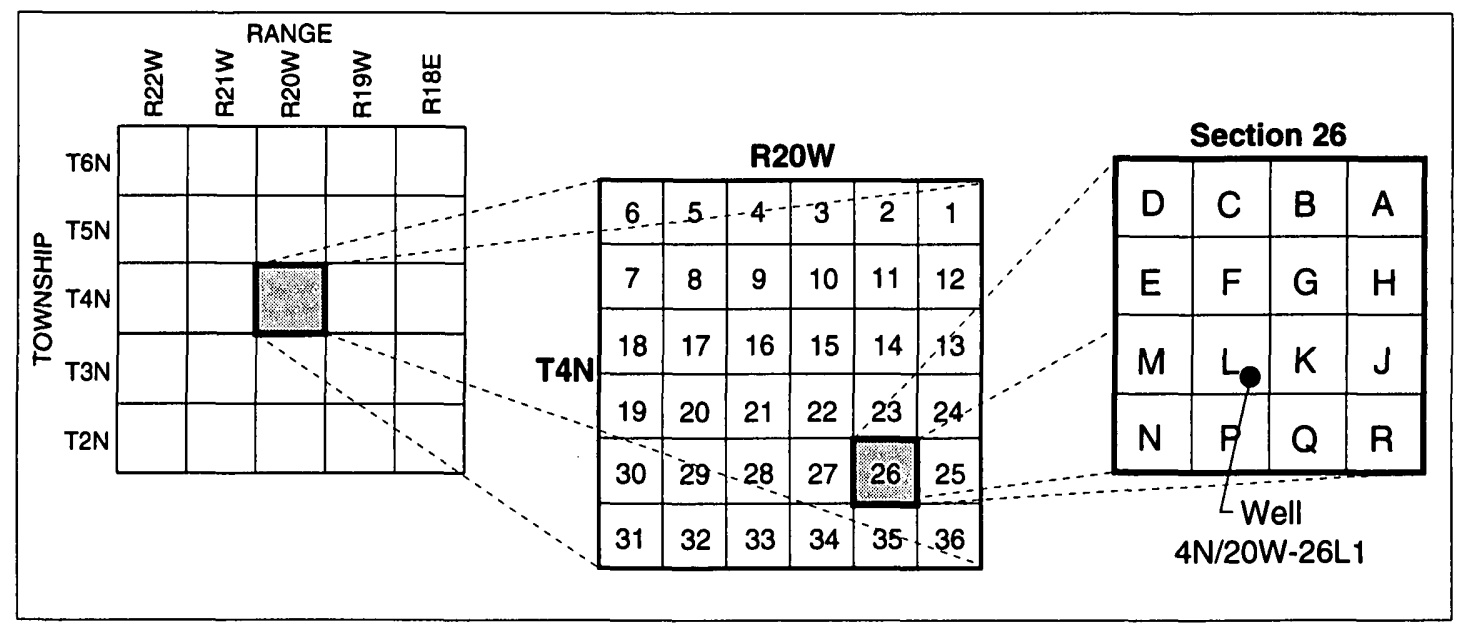

Well-numbering diagram 


\title{
EVALUATION OF SURFACE-WATER/GROUND-WATER INTERACTIONS IN THE SANTA CLARA RIVER VALLEY, VENTURA COUNTY, CALIFORNIA
}

\author{
By Eric G. Reichard, Steven M. Crawford, Katherine Schipke Paybins, Peter Martin, Michael Land, and
} Tracy Nishikawa

\section{ABSTRACT}

The interactions of surface water and ground water along the Santa Clara River in Ventura County, California, were evaluated by analyzing river-discharge and water-quality data and geohydrologic information collected by the U.S. Geological Survey between 1993 and 1995 for the Piru, Fillmore, and Santa Paula subbasins. Measurements of discharge and water quality were made at multiple locations along the Santa Clara River and its tributaries at eight different time periods during different releases from Lake Piru. Geologic, hydraulic, and water-quality data were collected from three new multiple-completion ground-water monitoring wells. These data, together with data collected as part of the U.S. Geological Survey Southern California Regional Aquifer-System Analysis (RASA) study, were analyzed in order to quantify rates and locations of ground-water recharge and discharge within the river, characterize the correlation of recharge and discharge rates with ground-water conditions and reservoir releases, and better characterize the three-dimensional ground-water flow system.

Analysis of the data indicates that the largest amount of ground-water recharge from the river consistently occurs in the Piru subbasin. Some ground-water recharge from the river may occur in the upper part of the Fillmore subbasin. Increases in sulfate concentrations indicate that increases in flow at the lower ends of the Piru and Fillmore subbasins result from high-sulfate ground-water discharge. Increases in flow in the lower part of the Santa Paula subbasin are not accompanied by significant sulfate increases. Several sets of regressions indicate possible correlation between net flow changes in the river and depths to ground water and release rates from Lake Piru. These statistical relations may be of use for evaluating alternative Lake Piru release strategies.

Data on the stable isotopes of hydrogen and oxygen from the ground-water monitoring wells that were installed as part of this investigation were used to distinguish between zones affected by recharge from the Santa Clara River and zones affected by recharge from local precipitation. Tritium data from a new multiple-completion monitoring site indicate that near the river in the upper Santa Paula subbasin, recent (post-1950) recharge water is not present at depths greater than about 350 feet below land surface. Water-level and lithologic data from the monitoring site indicate that the river and the Shallow aquifer have only limited hydraulic connection to the underlying aquifers at this location. Water-level data from the Shallow aquifer and from an in-stream drive point were used in an analytic model to estimate hydraulic properties governing stream-aquifer interactions in the upper Santa Paula subbasin. Hydraulic conductivities in all the USGS monitoring wells were estimated on the basis of slug tests. 


\section{INTRODUCTION}

This report provides an analysis of the interaction of surface water and ground water along the Santa Clara River in Ventura County (fig. 1). Because the Santa Clara River is the main source of recharge to ground water in Ventura County, improved understanding of stream-aquifer interactions along the river and its tributaries is important to water managers. To address this need, a study was done in cooperation with the United Water Conservation District (UWCD). As part of the study, surface-water and ground-water data were collected and analyzed in order to quantify rates and locations of ground-water recharge and discharge within the river; to characterize the correlation between ground-water recharge and discharge rates, ground-water conditions, and reservoir releases; and to better characterize geohydrologic properties relevant to surface-water/ground-water interaction.

The authors thank UWCD for its support of this study and Doug Maurer, David Morgan, Steven Bachman, Paul Barlow, Tony Buono, Peter Dal Pozzo, Robert Fleck, Randy Hanson, Clark Londquist, Robert Meyer, Keith Prince, and Ken Turner for their comments and reviews. The editing of Jerrald Woodcox, the illustrations of Rudolph Contreras, the layout of Jim Baker, and the field and office work of Greg Mendez, Michael Kuster, and Daniel Swope are gratefully acknowledged. The authors thank Juan Rico and Norman Wilkinson, City of Santa Paula, for providing drill sites.

\section{DESCRIPTION OF STUDY AREA}

The Santa Clara River is in the Santa ClaraCalleguas Hydrologic Unit in southern California (fig. 1) and has a drainage area of approximately 2,000 $\mathrm{mi}^{2}$. Average precipitation ranges from $14 \mathrm{in} / \mathrm{yr}$ at Port Hueneme (fig. 1) to as much as $25 \mathrm{in} / \mathrm{yr}$ in the mountains to the north and east. The focus of this study was on surface-water/ground-water interactions along the Santa Clara River within Ventura County. In this predominantly agricultural area, the river flows through five ground-water subbasins: Piru, Fillmore, Santa Paula, the Montalvo Forebay of the Oxnard Plain, and Mound.

The UWCD operates two facilities in the area: Lake Piru and the Freeman Diversion (see figure 1). Lake Piru-on Piru Creek, a tributary to the Santa Clara River-is operated to collect water in the wet winter months and release water during the late summer and autumn. River water diverted at the Freeman Diversion is used for artificial recharge at the Saticoy and El Rio spreading grounds in the Oxnard Plain and for direct delivery to water users within the Oxnard Plain and Pleasant Valley (fig. 1). The watermanagement issues of concern for this study relate to surface-water/ground-water interactions along the Santa Clara River system between these two facilities. Therefore, the discussion in this report deals mostly with the Piru, Fillmore, and Santa Paula subbasins. Average annual flow at the U.S. Geological Survey (USGS) gage on Piru Creek, which is just downstream from Lake Piru (see site 6 in figure 1) during the past 40 years has been about $40 \mathrm{ft}^{3} / \mathrm{s}$. Controlled releases have ranged from 100 to $350 \mathrm{ft}^{3} / \mathrm{s}$. Other major tributaries that flow into the Santa Clara River within the three subbasins are Sespe Creek and Santa Paula Creek. Mean annual streamflow in the Santa Clara River at the Freeman Diversion has been about 255 $\mathrm{ft}^{3} / \mathrm{s}$ during the past 40 years (R.T. Hanson, USGS, written commun., 1997). An estimated average of 85 $\mathrm{ft}^{3} / \mathrm{s}$ can be diverted annually through the Freeman facilities (Steven Bachman, UWCD, written commun., 1996).

\section{Geology}

The lithologic units of most significance for ground-water supply in the Santa Clara-Calleguas Hydrologic Unit are the Santa Barbara Formation of late Pliocene to early Pleistocene age, the San Pedro Formation of early Pleistocene age, deposits of late Pleistocene age, and deposits of Holocene age. These units overlie partly consolidated and consolidated rocks of Tertiary and older age (California Department of Water Resources, 1956).

The Santa Barbara Formation overlies consolidated rocks of Tertiary age in most of the Santa Clara River Valley and consists of marine sandstone, siltstone, mudstone, and shale (Weber and others, 1973). The formation is as much as $5,000 \mathrm{ft}$ thick in the Ventura area (Yerkes and others, 1987). Because the formation mostly consists of low-permeability sediments and contains water of poor quality in most of the study area (Turner, 1975), it is not considered an important source of ground water.

The San Pedro Formation overlies the Santa Barbara Formation in most of the Santa Clara River Valley and is as much as $5,000 \mathrm{ft}$ thick in the vicinty of 


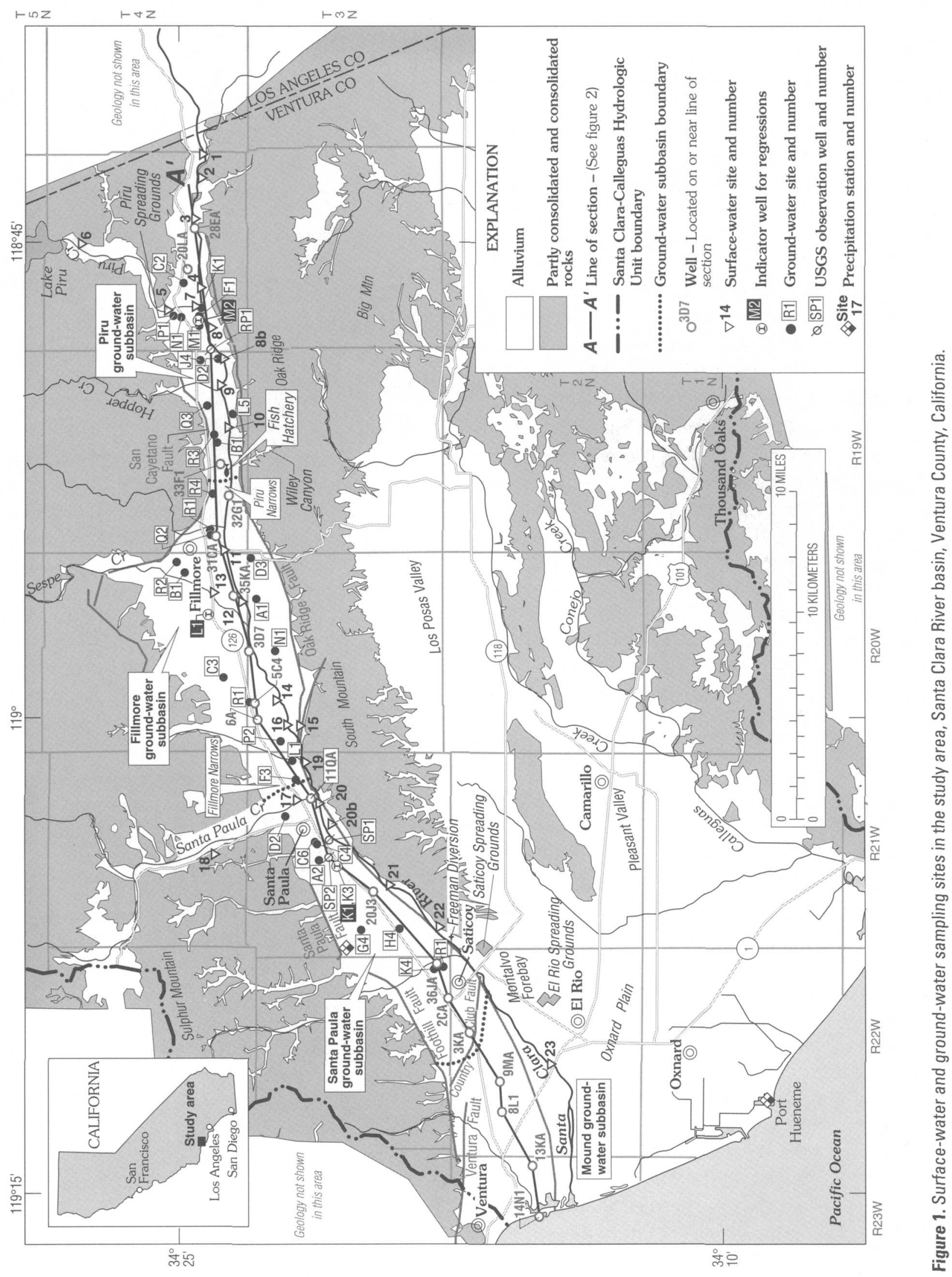


Santa Paula (Bailey and Jahns, 1954). The lower part of the formation consists of weakly indurated very fine sand to medium-grained fossiliferous sand with occasional gravel layers of shallow marine origin. Dibblee (1992) separated these deposits and placed them in a formation he designated "Las Posas Sand." The Las Posas Sand reaches a miximum thickness of more than 2,000 ft in the Santa Clara River Valley (Dibblee, 1992). The upper part of the San Pedro Formation consists of lenticular layers of sand, gravel, silt, and clay. Age estimates for the lower and upper parts of the San Pedro Formation are 600,000 and 200,000 yr B.P., respectively (Yerkes and others, 1987). Large-scale sea-level fluctuations during that period resulted in the deposition of continuous, laterally extensive coarse-grained materials above erosional unconformities. These coarse basal units potentially are a major source of water to wells.

The deposits of late Pleistocene age unconformably overlie the San Pedro Formation and contain a coarse-grained basal unit in most of the Santa Clara-Calleguas Hydrologic Unit (Turner, 1975; Weber and others, 1973). These deposits, which are generally less folded than are underlying older deposits, are described by Turner (1975) as being of continental and shallow marine origin, but are considered to be of alluvial origin in the Santa Clara River subbasins (California Department of Water Resources, 1975). The deposits of late Pleistocene age are, in turn, overlain by alluvial and fluvial deposits of Holocene age. The basal sand and gravel units within these deposits, which were laid down by the ancestral Santa Clara River at the end of the last glacial stage (approximately 10,000 yr B.P.), range in thickness from 10 to $200 \mathrm{ft}$.

The greatest thickness of unconsolidated deposits in the Santa Clara-Calleguas Hydrologic Unit occurs in the Santa Clara River subbasins. The San Pedro Formation is exposed in the hills to the north of the Santa Paula and Mound subbasins. In the Fillmore and Piru subbasins, the ground-water system is bounded by non-water-bearing Tertiary deposits that have been thrust over the San Pedro Formation along the San Cayetano Fault, a north-dipping reverse fault (fig. 1) (California Department of Water Resources, 1975). The Oak Ridge Fault, a south-dipping reverse fault, closely parallels the base of South Mountain. The non-water-bearing Tertiary deposits that are thrust up along the fault plane bound the Piru, Fillmore, and
Santa Paula ground-water subbasins (Dibblee, 1991, 1992). Another south-dipping reverse fault, the Country Club Fault, forms the boundary between the Santa Paula and Mound subbasins (California Department of Water Resources, 1975). Ground-water modeling done as part of the USGS RASA study indicates that the Country Club Fault causes some restriction of groundwater flow between the two subbasins (R.T. Hanson, USGS, written commun., 1997).

Two structural features of importance for surface-water/ground-water interaction are the Piru and Fillmore Narrows (see figure 1). Constrictions in the width of the unconsolidated deposits at these locations can cause ground water to discharge to the Santa Clara River.

\section{Aquifers}

Five major aquifers have been identified by previous investigators in the Santa Clara-Galleguas Hydrologic Unit (table 1): the Shallow and Oxnard aquifers within the alluvial deposits of Holocene age, the Mugu aquifer within the deposits of late Pleistocene age, the Hueneme aquifer within the upper part of the San Pedro Formation, and the Fox Canyon aquifer within the basal part of the San Pedro Formation (California Department of Water Resources, 1956; Turner, 1975). In this report, aquifers have been defined on the basis of analysis and correlation of lithologic and geophysical data collected as part of this study and the USGS RASA study. In this report, the Hueneme aquifer is separated into upper and lower parts. In wells, the lower Hueneme aquifer is differentiated from the upper Hueneme aquifer by longer drill times, indicating more consolidated materials. A generalized cross section through the Santa Clara River Valley is shown in figure 2. The Shallow aquifer, which consists of sand and gravel along the Santa Clara River, extends from the land surface to a depth of approximately 60 to $80 \mathrm{ft}$.

Table 1. Lithologic units and aquifers in the study area

\begin{tabular}{|c|c|c|}
\hline Geologic series & Lithologic unit & Aquifers \\
\hline Holocene & Alluvial deposits & $\begin{array}{l}\text { Shallow } \\
\text { Oxnard }\end{array}$ \\
\hline Upper Pleistocene & $\begin{array}{l}\text { Alluvial and } \\
\text { shallow marine } \\
\text { deposits }\end{array}$ & Mugu \\
\hline Lower Pleistocene & $\begin{array}{l}\text { San Pedro } \\
\text { Formation- } \\
\text { Las Posas Sand }\end{array}$ & $\begin{array}{l}\text { Hueneme (upper } \\
\text { and lower) } \\
\text { Fox Canyon }\end{array}$ \\
\hline
\end{tabular}






\section{EXPLANATION}

? Well and abbreviated number - Used to define geologic structure. ( indicates trun-

I Fault - Dashed where cated depth of well) TD - total depth of well

?- Contact - Dashed where approximately located; queried where uncertain

Figure 2. Generalized geohydrologic section through the Santa Clara River basin, Ventura County, California. 
The Oxnard aquifer, which consists of the basal sand and gravel deposits of Holocene age, extends to a depth of approximately 150 to $200 \mathrm{ft}$ below land surface. The Mugu aquifer, which consists of the basal part of the upper Pleistocene deposits, extends from about $200 \mathrm{ft}$ below land surface to about $350 \mathrm{ft}$. The upper Hueneme, lower Hueneme, and Fox Canyon aquifers underlie the Mugu aquifer throughout most of the Santa Clara River Valley. The combined thickness of these aquifers ranges from less than $500 \mathrm{ft}$ in the eastern Piru subbasin to more than $8,000 \mathrm{ft}$ in the Fillmore and Santa Rosa subbasins (fig. 2).

In the Piru subbasin, there appears to be no confining unit between the Oxnard aquifer and the overlying Shallow aquifer. As described later in this report, data from USGS monitoring well SP1 indicate that, near the Santa Clara River in the northern part of the Santa Paula subbasin, the Shallow aquifer is underlain by a thick clay layer, and the Oxnard aquifer seems to be absent. Data from a second USGS monitoring well, SP2, indicate that, away from the river in the northern part of the Santa Paula subbasin, the Oxnard aquifer is present but the Shallow aquifer is predominantly clay and has limited hydraulic connection to the Oxnard aquifer. In the southern part of the Santa Paula subbasin, the present river channel lies south of the Oak Ridge Fault, where the Shallow aquifer overlies older (late Pliocene to early Pleistocene) deposits adjacent to South Mountain (Law/Crandall, Inc., 1993). Hence, interaction between the Shallow aquifer and the Oxnard aquifer is limited.

Supply wells in the Piru, Fillmore, and Santa Paula subbasins draw water from multiple aquifers. Flowmeter data indicate that wells perforated in both the Oxnard and Mugu aquifers tend to derive most of their water from the Oxnard aquifer. In the Santa Clara subbasins, where the deposits that form the Mugu aquifer are relatively coarse, wells perforated in both the Mugu and Hueneme aquifers tend to derive most of their water from the Mugu aquifer (R.T. Hanson, USGS, oral commun., 1997). Because of the extreme thickness of the San Pedro Formation, wells are generally not drilled deeper than the Hueneme aquifer, which is in the upper part of the San Pedro Formation.

The geographic information system (GIS) developed as part of the USGS RASA project (Predmore and others, 1997) was used to roughly quantify the relative amounts of ground water pumped from different depths within the aquifer system. The following results are based on data from pumped wells in 1993 for which perforation data are available (which accounts for only about 60 percent of the total pumpage in the three subbasins) and on the assumption that the top of the perforated interval of a well is an indicator of where water is being drawn from. About 15 percent of the pumpage came from wells with tops of perforations $100 \mathrm{ft}$ below land surface or shallower (considered to generally represent the Shallow aquifer); about 50 percent came from wells with tops of perforations between 100 and $200 \mathrm{ft}$ below land surface (considered to generally represent the Oxnard aquifer); about 20 percent came from wells with tops of perforations between 200 and $350 \mathrm{ft}$ below land surface (considered to generally represent the Mugu aquifer); and about 15 percent came from wells with tops of perforations deeper than $350 \mathrm{ft}$ (considered to generally represent the Hueneme aquifer).

\section{PREVIOUS WORK}

Densmore and others (1992) measured discharge and several chemical constituents and properties of water at 23 locations along the Santa Clara River and its tributaries during four different periods in 1991-including a period of zero release from Lake Piru (see fig. 1) that was considered to represent base flow, and periods with releases of 100,272 , and 391 $\mathrm{ft}^{3} / \mathrm{s}$. For the zero-release condition, the only flow in the river was the result of discharging ground water at the Fillmore Narrows at the lower end of the Fillmore subbasin. This water was characterized by high specific conductance $(2,000 \mu \mathrm{S} / \mathrm{cm})$ and high sulfate concentration $(800 \mathrm{mg} / \mathrm{L})$. For the 100 - and $272-\mathrm{ft}^{3} / \mathrm{s}$ releases, all the release water infiltrated into the ground-water system (or was diverted) before reaching the Freeman Diversion. Only for the $391-\mathrm{ft}^{3} / \mathrm{s}$ release did water flow all the way to the diversion.

Mass-balance computations on sulfate concentrations and stable isotopes of oxygen and hydrogen suggested that ground-water discharge at the Fillmore Narrows increased with increasing release rates. Thus, increased upstream infiltration may have led to increased discharge at the lower end of the Fillmore subbasin. 


\section{APPROACH}

The data-collection efforts in this study, which supported and expanded the efforts of Densmore and others (1992), had three main components: (1) measurements of discharge and water quality were made at the same locations (as those of Densmore and others, 1992) along the Santa Clara River and its tributaries during several different time periods and under different flow conditions regulated by releases from Lake Piru; (2) geologic and hydraulic data were collected and water-quality samples were collected and analyzed from three multiple-completion ground-water monitoring wells installed during this study; and (3) water levels were continuously monitored at these wells and in drive points in the Santa Clara River near two of the wells. These data, together with data collected as part of the USGS RASA study (see Izbicki and others, 1995), were analyzed in order to quantify rates and locations of ground-water recharge and discharge within the river, to characterize the correlation between recharge and discharge rates and ground-water conditions and reservoir releases, and to better characterize the geohydrologic properties relevant to the interaction of ground water and surface water.

An additional set of tasks completed as part of this project involved conducting, analyzing, and modeling a dye-tracer test. The goal of the tracer test was to test some of the inferred recharge/discharge processes discussed in this report and to develop estimates of travel times, velocities, dispersion, and stream-channel characteristics. The results of this work are described by Paybins and others (1998) and Nishikawa and others (1999). Dye-test results indicated that, during a controlled release of approximately $170 \mathrm{ft}^{3} / \mathrm{s}$ from Lake Piru, the mean travel time from Lake Piru to the Freeman Diversion was approximately 18 hours. This provides useful information on the time required for transient effects to propagate downstream.

\section{ANALYSIS OF SURFACE-WATER DATA}

In this study, the discharge measurements and water-quality sampling and analysis were repeated eight times during 1993-95 at the same locations measurements were made and sampling was done in
1991 by Densmore and others (1992). Two of the eight sets of data were collected under zero-release conditions and six were collected during releases. Flow and water-quality results (focusing on sulfate and the stable isotopes of hydrogen and oxygen) are described and compared with those of Densmore and others (1992) in the sections that follow. There is an important difference in conditions between the data-collection periods of the two studies: conditions during the 199395 measurements were much wetter than those in 1991.

\section{Flow Measurements}

The results of flow measurements for all eight sets of data collected during this study are given in Appendix 1. Discussion in this report focuses on the sites on Piru Creek and the Santa Clara River between Lake Piru (site 6) and the Freeman Diversion (site 22), sites which are influenced by releases from Lake Piru. Discharge and sulfate concentrations for these sites are shown in figure 3. Measurement of changes in sulfate concentrations in surface water along the river are important because they can provide information on the possible sources of inflow to the river.

Two of the data sets-for the periods August 15-20, 1993 (fig. 3A), and July 25-August 2, 1994 (fig. $3 E$ )—were collected during zero-release (base-flow) conditions. The other six data sets were collected during releases from Lake Piru: August 24, 1993 (fig. 3B); August 30-September 15, 1993 (fig. 3C); October 26-30, 1993 (fig. 3D); September 19-24, 1994 (fig. $3 F$ ); October 25-27, 1994 (fig. 3G); and October 10-13, 1995 (fig. 3H).

\section{Sources of Error and Uncertainty in Flow Measurements}

There are several sources of error and uncertainty associated with the flow measurements made as part of this study. It is extremely important to keep these in mind when interpreting the results. In spite of the presence of multiple sources of possible errors, however, it is possible to analyze the data and to draw preliminary inferences, particularly regarding patterns of flow changes that are present in multiple data sets. Clearly, additional follow-up data collection is essential to test these inferences.

One source of error is in the flow measurements themselves. Flow measurements were made using guidelines outlined by Carter and Davidian (1968). 


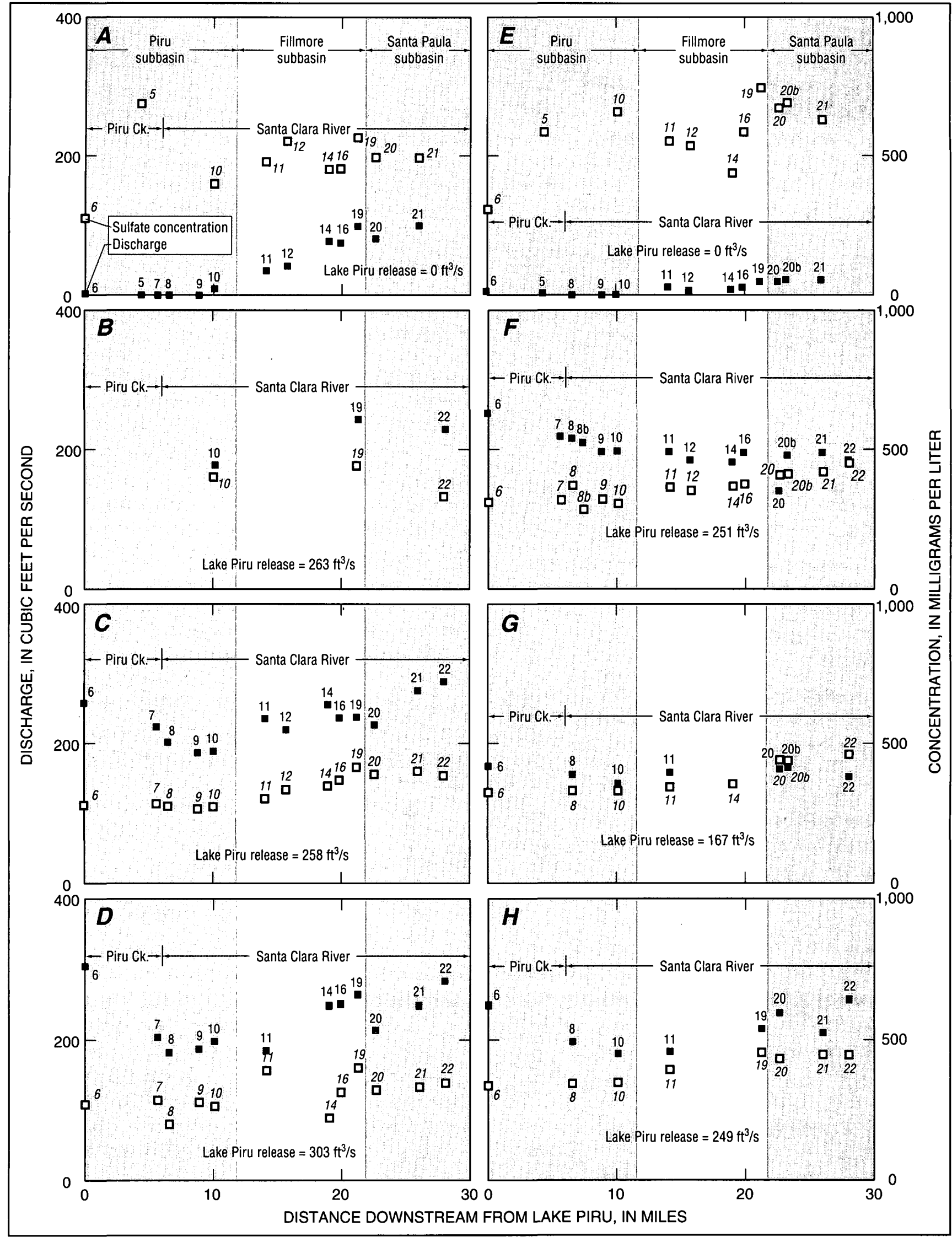

Figure 3. Discharge measurements and sulfate concentrations at surface-water monitoring sites in the Santa Clara River basin, Ventura County, California. A, August 15-20, 1993. B, August 24, 1993. C, August 30-September 15, 1993. D, October 26-30, 1993. E, July 25-August 2. 1994. F, September 19-24, 1994. G, October 25-27, 1994. H, October 10-13, 1995. 
Most measurements were rated as good-to-fair, indicating possible errors of 5 to 8 percent. Therefore, some of the apparent changes in flow along the river may not be significant.

A second source of possible error is in unmeasured inflows to and outflows from the river. These could include diversions, tributaries, and return flows. There are likely several small unmeasured diversions along the course of the river (Peter Dal Pozzo, UWCD, oral commun., 1997). A fish hatchery between sites 10 and 11 pumps large amounts of water (on the order of 10,000 acre-ft/yr) from the lowermost end of the Piru subbasin. Some of this water may drain back into the river at the upper end of the Fillmore subbasin as return flow.

A third source of error is that each set of discharge measurements were made over a period of days, during which time conditions may have changed. Of particular importance were potential changes in Lake Piru release rates. Average daily flow values measured at the USGS gage at site 6 are given in table 2. As can be seen, there is some variability in these values for most of the measurement periods. For each period, depending on when measurements at individual sites were made, some of the changes in flow between sites may be the result of changes in releases, not inflows or outflows along the river.

\section{Flow Changes in the Piru Subbasin}

As shown in Appendix 1, for all data-collection periods, all flow entering the Piru subbasin from Los Angeles County to the east at site 1 infiltrates (or is diverted) before it reaches site 4 , just upstream from Piru Creek (see figure 1). Data from the two zerorelease periods, August 15-20, 1993 (fig. 3A), and July 25-August 2, 1994 (fig. 3E), show zero river flow in the middle part of the subbasin (sites 8 and 9). In both zero-release periods there is flow at site 10 , the lowermost site in the Piru subbasin and increased flow

Table 2. Releases from Lake Piru and diversions at Piru spreading grounds during data-collection periods

$\left[\mathrm{ft}^{3} / \mathrm{s}\right.$, cubic feet per second; - , no data]

\begin{tabular}{|c|c|c|c|c|c|c|c|}
\hline Data- collection perlod & Date & $\begin{array}{c}\text { Release } \\
\text { from } \\
\text { Lake } \\
\text { Piru } \\
\left(\mathrm{ft}^{3} / \mathrm{s}\right)\end{array}$ & $\begin{array}{l}\text { Diversion } \\
\text { at Piru } \\
\text { spreading } \\
\text { grounds } \\
\left(\mathrm{ft}^{3} / \mathrm{s}\right)\end{array}$ & Data- collection period & Date & $\begin{array}{c}\text { Release } \\
\text { from } \\
\text { Lake } \\
\text { PIru } \\
\left(\mathrm{ft}^{3} / 8\right)\end{array}$ & $\begin{array}{l}\text { Diversion } \\
\text { at Piru } \\
\text { spreading } \\
\text { grounds } \\
\left(\mathrm{ft}^{3} / 8\right)\end{array}$ \\
\hline \multirow[t]{2}{*}{ Aug. 24, 1993} & $8 / 23$ & 263 & - & \multirow[t]{5}{*}{ Oct $26-30,1993$} & $10 / 26$ & 286 & 53 \\
\hline & $8 / 24$ & 263 & - & & $10 / 27$ & 282 & 57 \\
\hline \multirow[t]{18}{*}{ Aug. 30-Sept. 15, 1993} & $8 / 29$ & 248 & - & & $10 / 28$ & 286 & 56 \\
\hline & $8 / 30$ & 248 & - & & $10 / 29$ & 293 & 56 \\
\hline & $8 / 31$ & 248 & - & & $10 / 30$ & 302 & 62 \\
\hline & $9 / 1$ & 248 & - & \multirow[t]{7}{*}{ Sept. 19-24, 1994} & $9 / 18$ & 273 & - \\
\hline & $9 / 2$ & 248 & - & & $9 / 19$ & 267 & 一 \\
\hline & $9 / 3$ & 242 & - & & $9 / 20$ & 241 & - \\
\hline & $9 / 4$ & 245 & - & & $9 / 21$ & 241 & - \\
\hline & $9 / 5$ & 251 & - & & $9 / 22$ & 241 & - \\
\hline & $9 / 6$ & 246 & - & & $9 / 23$ & 208 & - \\
\hline & $9 / 7$ & 251 & - & & $9 / 24$ & 197 & - \\
\hline & $9 / 8$ & 250 & - & \multirow[t]{4}{*}{ Oct. $25-27,1994$} & $10 / 24$ & 174 & - \\
\hline & $9 / 9$ & 250 & - & & $10 / 25$ & 174 & 3 \\
\hline & $9 / 10$ & 251 & - & & $10 / 26$ & 174 & - \\
\hline & $9 / 11$ & 241 & - & & $10 / 27$ & 174 & - \\
\hline & $9 / 12$ & 251 & - & \multirow[t]{5}{*}{ Oct. $10-13,1995$} & $10 / 9$ & 213 & - \\
\hline & $9 / 13$ & 254 & - & & $10 / 10$ & 219 & - \\
\hline & $9 / 14$ & 260 & - & & $10 / 11$ & 240 & - \\
\hline & $9 / 15$ & 262 & - & & $10 / 12$ & 248 & - \\
\hline Oct. $26-30,1993$ & $10 / 25$ & 286 & 55 & & $10 / 13$ & 248 & - \\
\hline
\end{tabular}


at site 11, the uppermost site in the Fillmore subbasin. This increase in flow seems to be due to ground-water discharge at the Piru Narrows. For the periods during releases, figures $3 C, D, F, G$, and $H$ all show consistent decreasing flow from Lake Piru (site 6) downstream through site 8 (Torrey Road). This result is consistent with the conclusion of Densmore and others (1992) that during releases from Lake Piru, ground-water recharge always occurs in the middle part of the Piru subbasin. The data collected during releases also show generally increasing flow associated with the Piru Narrows. For the three data sets during releases with measurements at both sites 9 and 10 , one shows an increase in flow (fig. 3D) and two show constant flow (figs. $3 C, F$ ). For the five data sets during releases with measurements at both sites 10 and 11 , three show increases in flow (figs. $3 C, G$, and $H$ ), one shows constant flow (fig. $3 F$ ), and one shows decreasing flow (fig. 3D). As mentioned in the prior discussion of possible errors and uncertainties, flow changes between sites 10 and 11 may be affected by fish hatchery operation.

\section{Flow Changes in the Fillmore Subbasin}

In the Fillmore subbasin, there is some evidence of decreasing flow-indicating ground-water recharge - in the upper part of the subbasin (between sites 11 and 12). Three of the four data sets with measurements at both sites 11 and 12 (figs. $3 C, E$, and $F$ ) show flow decreases; the fourth (fig. $3 A$ ) shows a flow increase, however. In general, there appears to be an overall increase in flow between the upper part of the Fillmore subbasin (sites 11 and 12) and the lower part (sites 16 and 19). The increases in flow between sites 12 and 14 are likely the result of shallow, low-sulfate ground-water discharge associated with Sespe Creek. The increases in flow between sites 14 and 19 are likely due to ground-water discharge associated with the Fillmore Narrows.

The data are inconclusive regarding the processes occurring between the lower end of the Fillmore subbasin (site 19) and the upper end of Santa Paula subbasin (site 20). Of the five data sets with measurements at both sites, three show flow decreases (figs. $3 A, C$, and $D$ ), one shows an increase (fig. $3 H$ ), and one shows no change (fig. $3 E$ ). Along this reach, there is a small amount of inflow from Santa Paula Creek (see site 17 in Appendix 1) as well as an ungaged diversion (Peter Dal Pozzo, UWCD, oral commun.,
1997). Measurements for September 19-24, 1994 (fig. $3 F$ ), show a very large decrease in flow between sites 16 and 20 (no measurement was made at site 19). However, an additional measurement was made just downstream from site 20 at site $20 \mathrm{~b}$, which is adjacent to the USGS monitoring well SP-1. Measured flow at site $20 \mathrm{~b}\left(191 \mathrm{ft}^{3} / \mathrm{s}\right)$ was back up to nearly the same rate as that at site $16\left(195 \mathrm{ft}^{3} / \mathrm{s}\right)$. This may be the result of water that was diverted upstream from site 20 reentering the river.

\section{Flow Changes in the Santa Paula Subbasin}

Data generally indicate an increase in flow in the Santa Paula subbasin between sites 20 and 22. As described earlier, the Shallow aquifer in this part of the Santa Clara River directly overlies Tertiary deposits. As is discussed later in the "Surface-Water-Quality Measurements" section, no significant increases in sulfate concentrations occur along this reach (see figure 3 and Appendix 1). Therefore, unlike at the Piru and Fillmore Narrows, this flow increase seems not to be caused by discharge of high-sulfate ground water. It is possible that this flow increase in the lower Santa Paula subbasin results from the discharge of ground water from the Shallow aquifer system that has sulfate concentrations similar to those in the river.

\section{Regression Analyses of Flow Measurements}

Regression analyses (table 3; Appendix 2) were used to quantify the relations between ground-water recharge to and discharge from the river with respect to Lake Piru releases and ground-water conditions. Net flow changes in each subbasin and total river flow at site 22 (Freeman Diversion) were regressed against releases from Lake Piru (site 6) and depths to water at indicator wells.

Net flow changes were computed for the Piru subbasin [defined as the difference between flow at Lake Piru (site 6) and flow at the upper end of the Fillmore subbasin (site 11)]; for the Fillmore subbasin [defined as the difference between flow at the upper end of the Fillmore subbasin (site 11) and flow at the upper end of the Santa Paula subbasin (site 20)]; and for the Santa Paula subbasin [defined as the difference between flow at the upper end of the Santa Paula subbasin (site 20) and flow upstream of the Freeman diversion (site 22)] for five sets of flow measurements 
Table 3. Results of regression analyses

[Regression equation and method: OLS, ordinary least-squares regression; IWLS, iteratively weighted least-squares regression. Dependent variable, in cubic feet per second: $L p$, net flow loss in Piru subbasin; $L f$, net flow loss in Fillmore subbasin; $L s p$, net flow loss in Santa Paula subbasin; $F$, flow at site 22 in Santa Clara River upstream of Freeman Diversion. Regression coefficients for independent variables: $R$, release from Lake Piru, in cubic feet per second; $G I$, depth, in feet, to water at Piru subbasin indicator well, 4N/18W-20M2; G2, depth, in feet, to water at Fillmore subbasin indicator well, 4N/20W-26L1; G3, depth, in feet, to water at Santa Paula subbasin indicator well, 3N/21W-16K1. <, actual value is less than value shown]

\begin{tabular}{|c|c|c|c|c|c|c|}
\hline \multirow{2}{*}{$\begin{array}{c}\begin{array}{c}\text { Regression } \\
\text { equation and } \\
\text { method }\end{array} \\
\text { 1a -- OLS } \\
\end{array}$} & \multirow[t]{2}{*}{$\begin{array}{l}\text { Regression } \\
\text { statistics }\end{array}$} & \multirow{2}{*}{$\begin{array}{c}\begin{array}{c}\text { Dependent } \\
\text { varlable }\end{array} \\
L p\end{array}$} & \multicolumn{2}{|c|}{$\begin{array}{l}\text { Regression coefflclents for } \\
\text { independent varlables }\end{array}$} & \multirow{2}{*}{$\begin{array}{c}\text { Constant } \\
-188\end{array}$} & \multirow{2}{*}{$\begin{array}{c}\mathrm{R}^{2} \\
0.95\end{array}$} \\
\hline & & & $0.71 R$ & $1.25 G 1$ & & \\
\hline & Standard error & & .16 & .39 & 38.1 & \\
\hline & t-ratio & & 4.46 & 3.24 & -4.93 & \\
\hline & P-value & & .022 & .048 & .016 & \\
\hline \multirow[t]{4}{*}{$1 b--$ IWLS } & & $L p$ & $.70 R$ & $1.4 \dot{6} G I$ & -203 & 1.00 \\
\hline & Standard error & & .05 & .12 & 11.9 & \\
\hline & t-ratio & & 14.33 & 11.49 & -17.0 & \\
\hline & $\mathrm{P}$-value & & .0007 & .0013 & .0004 & \\
\hline \multirow[t]{4}{*}{$2 a--O L S$} & & $L f$ & $.08 R$ & $3.75 G 2$ & -204.9 & .72 \\
\hline & Standard error & & .28 & 2.00 & 75.7 & \\
\hline & t-ratio & & .29 & 1.87 & -2.71 & \\
\hline & $\mathrm{P}$-value & & .7914 & .1577 & .0734 & \\
\hline \multirow[t]{4}{*}{$2 b$-- IWLS } & & $L f$ & $-.04 R$ & $5.09 G 2$ & -244.0 & .999 \\
\hline & Standard error & & .01 & .11 & 4.07 & \\
\hline & t-ratio & & -3.21 & 48.05 & -59.8 & \\
\hline & P-value & & .049 & $<.0001$ & $<.0001$ & \\
\hline \multirow[t]{4}{*}{$3 a--$ OLS } & & $L s p$ & $-.28 R$ & $3.61 G 3$ & -122.7 & .34 \\
\hline & Standard error & & .22 & 2.94 & 128.4 & \\
\hline & t-ratio & & -1.27 & 1.23 & -.96 & \\
\hline & P-value & & .274 & .287 & .393 & \\
\hline \multirow[t]{4}{*}{ 3b -- IWLS } & & $L s p$ & $-.28 R$ & $3.41 G 3$ & -112.6 & .34 \\
\hline & Standard error & & .22 & 2.84 & 124.2 & \\
\hline & t-ratio & & -1.28 & 1.20 & -.91 & \\
\hline & P-value & & .270 & .296 & .416 & \\
\hline \multirow[t]{4}{*}{$4 a--$ OLS } & & $F$ & $.49 R$ & $-3.52 G 1$ & 280.8 & .99 \\
\hline & Standard error & & .11 & .20 & 26.5 & \\
\hline & t-ratio & & 4.62 & -17.68 & 10.59 & \\
\hline & P-value & & 0.0099 & $<.0001$ & .0005 & \\
\hline \multirow[t]{4}{*}{$4 b$} & & $F$ & $.42 R$ & $-3.45 G 1$ & 292.9 & 1.00 \\
\hline & Standard error & & .01 & .03 & 2.97 & \\
\hline & t-ratio & & 32.13 & -113.26 & 98.49 & \\
\hline & P-value & & $<.0001$ & $<.0001$ & $<.0001$ & \\
\hline
\end{tabular}


made during releases in this study (excluding the partial data set for August 24, 1993) and for two sets of flow measurements made during releases in 1991 reported by Densmore and others (1992). These net flow changes are shown in figure 4. Flow-change computations for the 1991 data sets are incomplete because of missing data.

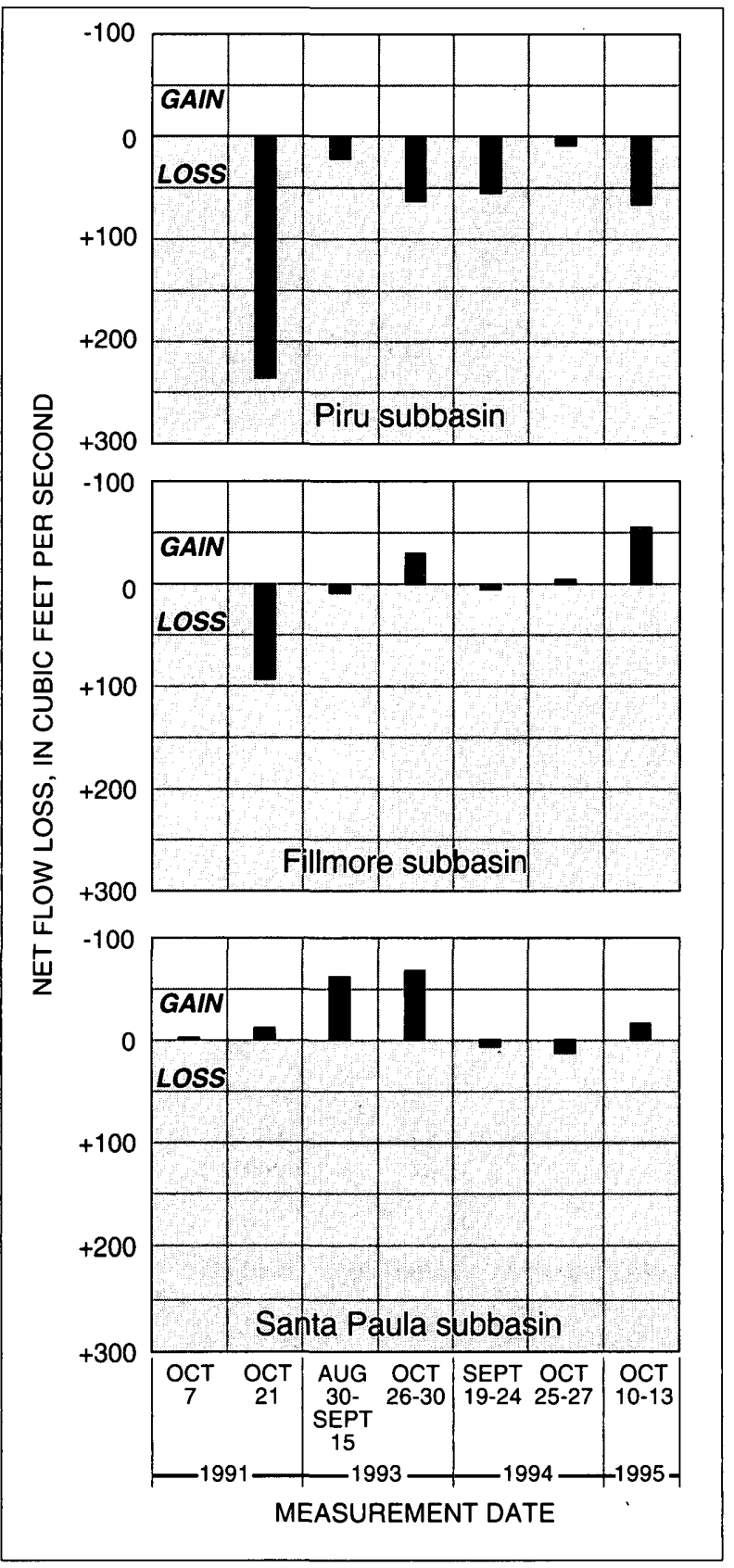

Figure 4. Net flow loss in the Piru, Fillmore, and Santa Paula subbasins, Santa Clara River basin, Ventura County, California.
Depths to ground water, measured during or close to the flow-measurement period, at wells used for long-term monitoring by UWCD in the three subbasins were used as an indicator of overall ground-water conditions for the subbasins. These indicator wells are not meant to represent the hydraulic conditions in the aquifer at the river; they simply provide a gross quantitative indication of the antecedent ground-water conditions for the releases. The indicator wells, shown in figure 1, are 4N/18W-29M2 for the Piru subbasin (well depth of $142 \mathrm{ft}$ below land surface with an unknown perforated interval), 4N/20W-26L1 for the Fillmore subbasin (perforated from $100 \mathrm{ft}$ to $397 \mathrm{ft}$ below land surface), and 3N/21W-16K1 for the Santa Paula subbasin (perforated from $105 \mathrm{ft}$ to $220 \mathrm{ft}$ below land surface). Long-term hydrographs for these three wells, along with precipitation and cumulative departure curves for precipitation stations at Santa Paula and Port Hueneme (see figure 1), are shown in figure 5. Conditions during 1991-95 ranged from nearhistorical-low ground-water levels in 1991 to nearhistorical-high levels in 1993-94. The three indicator wells show different amplitudes of water-level fluctuations. Water levels during the period 1990-95 fluctuated about $110 \mathrm{ft}$ in the Piru subbasin well, 4N/18W-29M2, and about $35 \mathrm{ft}$ in the Fillmore subbasin well, 4N/20W-26L1, and the Santa Paula subbasin well, 3N/21W-16K1.

Net streamflow loss (change) in each subbasin was regressed against release from Lake Piru and depth to ground water at the indicator well (as calculated in table 3 , losses are positive numbers, gains are negative). Total flow in the Santa Clara River upstream from the Freeman Diversion (site 22) was then regressed against release from Lake Piru and depth to ground water at the Piru subbasin indicator well. The Piru well was used for this regression because it has the largest fluctuations in depth to water. Ideally, one might want to use a combination of wells in all subbasins for a regression analysis. However, the small number of data sets precluded adding additional variables to the regression.

The data used for these regressions are tabulated in Appendix 2 and are shown graphically in figures 6 and 7. For the October 1993 data, the net flow losses in the Piru subbasin and total flow upstream from the Freeman Diversion were adjusted for the diversions at the Piru spreading grounds. Six to seven data sets were used for each regression. 


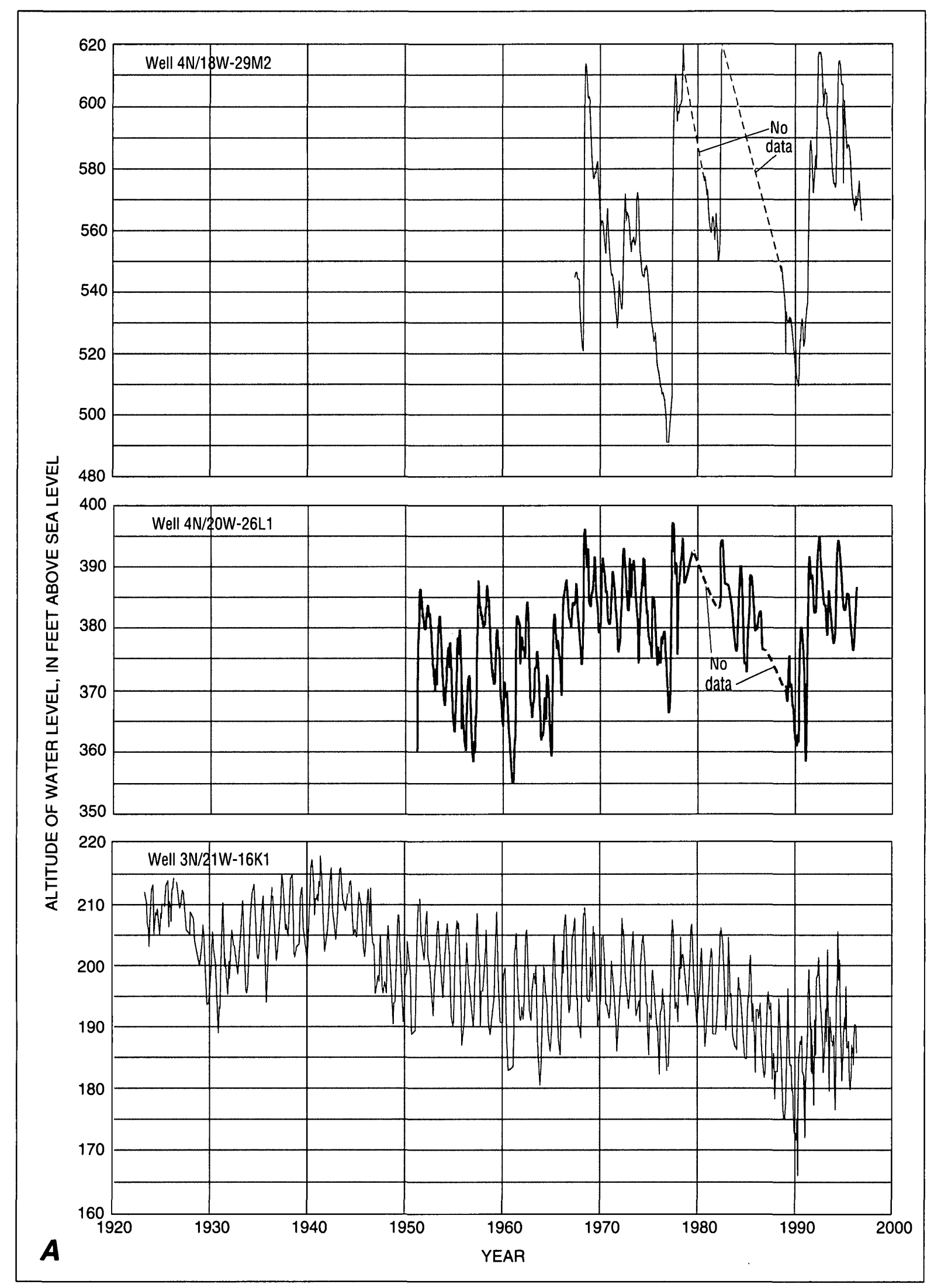

Figure 5. Hydrographs for selected wells (A), observed-precipitation and calculated-cumulative-departure curves for precipitation stations at Santa Paula and Port Hueneme (B), Santa Clara River basin, Ventura County, California 


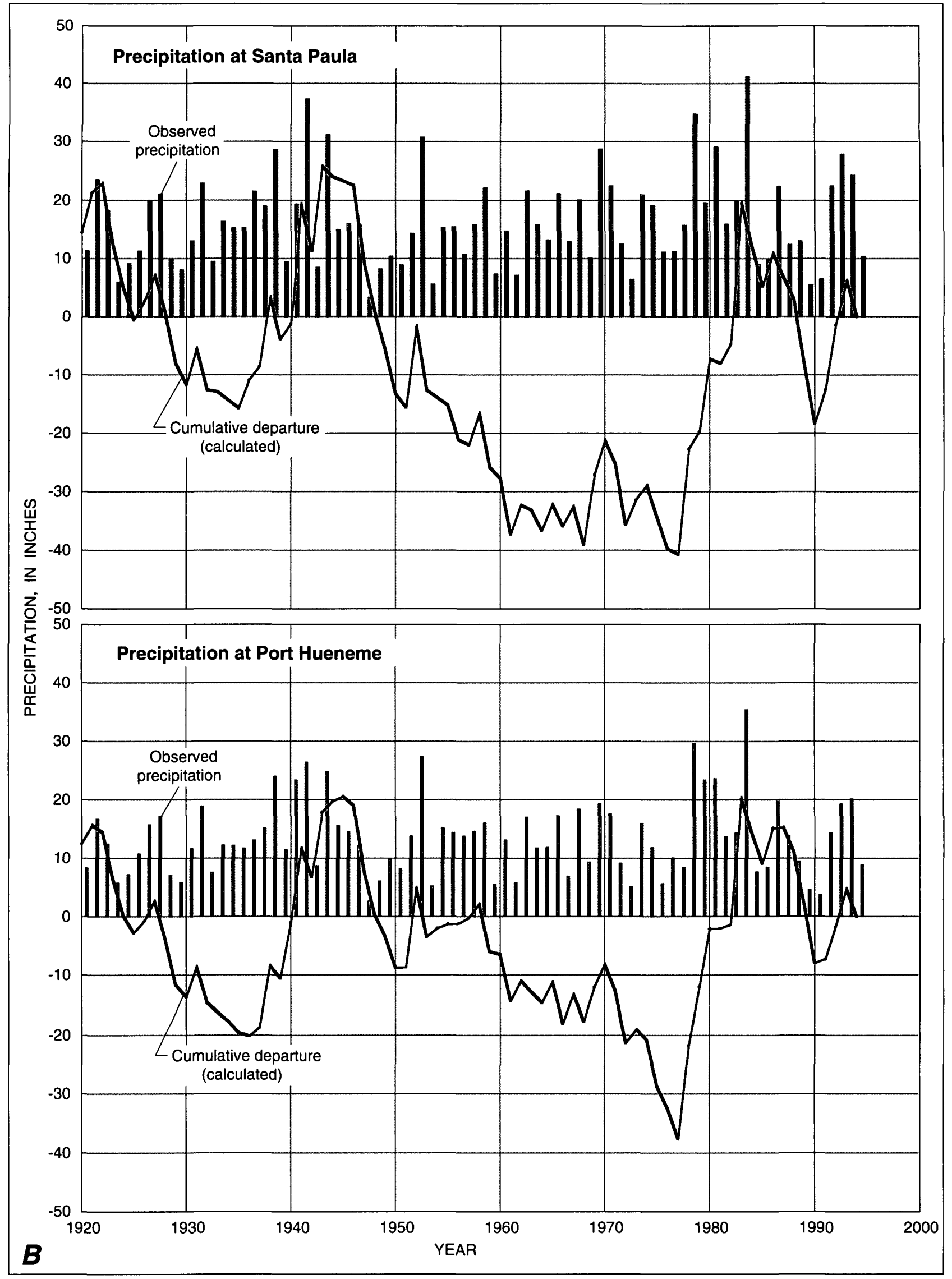

Figure 5.-Continued. 


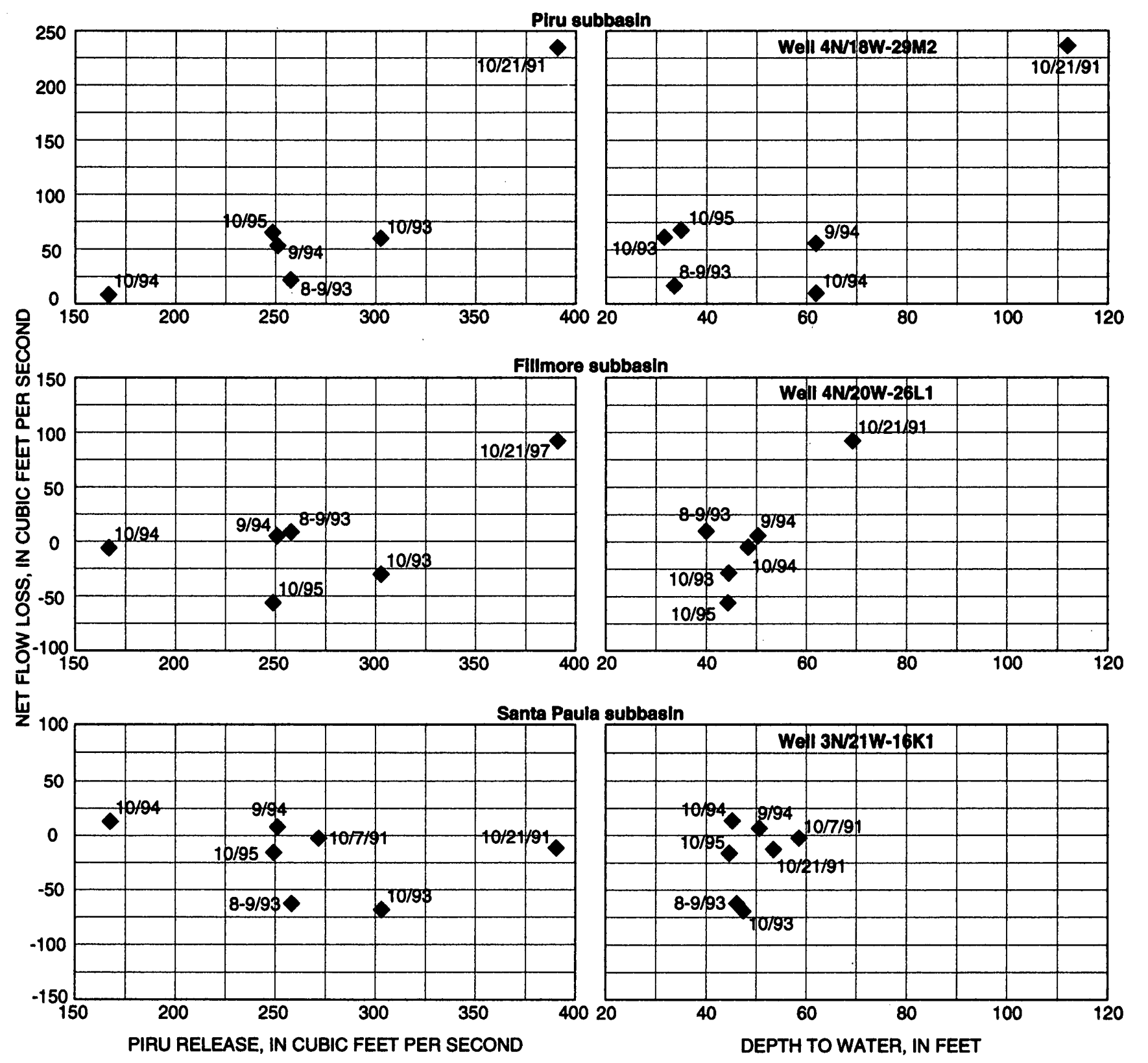

Figure 6. Net flow loss in Piru Creek and the Santa Clara River in the Piru, Fillmore, and Sante Paula subbasins as a function of relesse from Lake Piru and as a function of depth to ground water, Santa Clara River basin, Ventura County, California. (Negative net flow losses are gains in streamflow.)

Extreme caution is required in drawing implications from the regressions. First, the regressions are based on a very small number of data points. Second, as described earlier, there are multiple sources of uncertainty and potential error in all the data. Third, statistical correlation does not prove causation. Finally, the regression results are not valid outside the range of data used for the analysis.

The results of the regressions for the four dependent variables-flow loss in the Piru subbasin,
$L p$; flow loss in the Fillmore subbasin, $L f$, flow loss in the Santa Paula subbasin, Lsp; and flow at site 22, upstream from the Freeman Diversion, $F$-are given in table 3. For each dependent variable, two regression methods were applied: ordinary least-squares (OLS) regression, and an iteratively weighted least-squares regression (IWLS). IWLS is a robust regression method, which is considered appropriate for data sets in which outliers may have a large influence on regression results (Helsel and Hirsch, 1992). The 

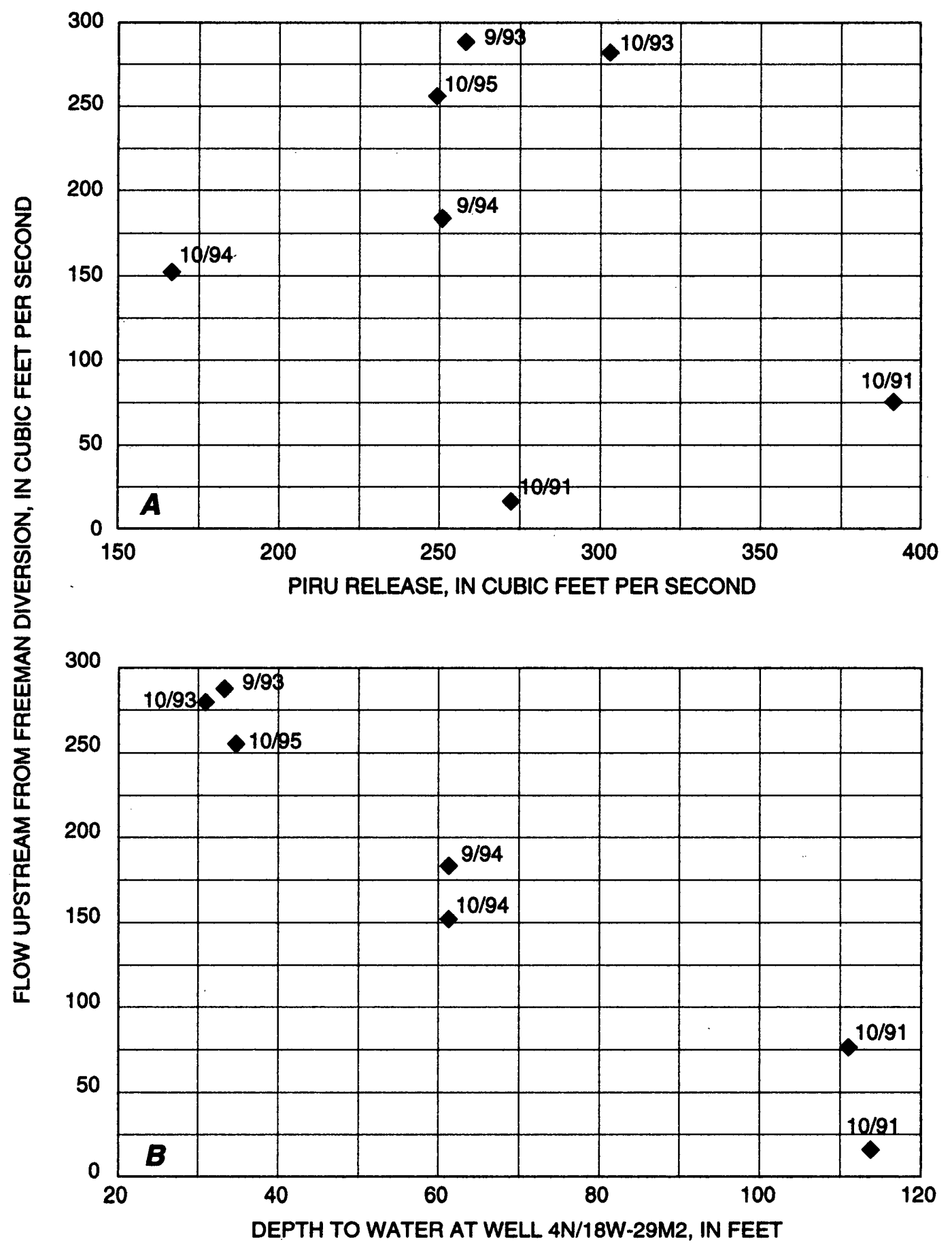

Figure 7. Flow in the Santa Clara River upstream from the Freeman Diversion (site 22) as a function of release from Lake Piru (A), and as a function of depth to ground water at well 4N/18W-29M2 (B), Santa Clara River basin, Ventura County, California.

specific weighting function used in the IWLS is the bisquare weight estimator (Mosteller and Tukey, 1977).

Regression equations $1 \mathrm{a}$ and $1 \mathrm{~b}$ in table 3 indicate that net flow loss in the Piru subbasin $(L p)$ seems to be statistically well explained by the quantity released from Lake Piru $(R)$ and the depth to ground water $(G l)$ at indicator well $4 \mathrm{~N} / 18 \mathrm{~W}-29 \mathrm{M} 2$. Note that the OLS regression results (1a) are very similar to the IWLS regression results (1b). As one would expect, flow loss (recharge) is positively correlated with both release from Lake Piru and depth to ground water. Because the Piru subbasin consistently has the largest net flow loss (see figures 3 and 4), this statistical relation may be useful in estimating or predicting net 
flow losses and ground-water recharge along the Santa Clara River.

Regression equation $2 \mathrm{a}$ in table 3 , which applies OLS, indicates that net flow loss in the Fillmore subbasin $(L f)$ is not as well correlated with the quantity of water released from Lake Piru $(R)$ and the depth to ground water $(G 2)$ at indicator well $4 \mathrm{~N} / 20 \mathrm{~W}-26 \mathrm{~L} 1$.

The t-ratio for the coefficient on $R$ indicates that the coefficient is not significant. Regression equation $2 b$, which uses IWLS, yields a larger coefficient on depth to ground water. Note that the IWLS regression applies zero weights to the August-September 1993 and the October 1995 data. As can be seen in figure 6, there is a strong apparent linear relation between net flow change in the Fillmore subbasin and depth to ground water if these two data points are excluded.

Regression equations $3 \mathrm{a}$ and $3 \mathrm{~b}$ in table 3 show that net flow loss in the Santa Paula subbasin $(L s p)$ is not statistically well explained by the quantity released from Lake Piru $(R)$ or the depth to ground water $(G 3)$ at indicator well $3 \mathrm{~N} / 21 \mathrm{~W}-16 \mathrm{~K} 1$. The $\mathrm{R}^{2}$ values and the $t$-ratios are low in both the OLS (3a) and the IWLS (3b) regressions. In contrast to the other two subbasins, flow loss in the Santa Paula subbasin is negatively correlated with release from Lake Piru. In other words, in the Santa Paula subbasin where flows are generally increasing (see figures 3 and 4), the flow increases appear to be positively correlated with Lake Piru releases (see figure 6).

Regression equations $4 \mathrm{a}$ and $4 \mathrm{~b}$ in table 3 show that flow $(F)$ in the Santa Clara River upstream from the Freeman Diversion (site 22) is statistically well explained by the quantity released from Lake Piru $(R)$ and the depth to ground water $(G l)$ at the Piru subbasin indicator well 4N/18W-29M2. Regression coefficients computed by the OLS (4a) are very similar to those computed by the IWLS (4b). Because the dependent variable is flow, rather than flow loss, it is negatively correlated with depth to ground water. In this case, the depth to ground water apparently explains most of the statistical correlation. The $\mathrm{R}^{2}$ value and the t-ratios for equation $4 \mathrm{a}$ are higher than those for the individual OLS regressions relating net changes in three subbasins (regressions equations 1a, 2a, and $3 a$ ). The regressions for the individual subbasins apparently do not account for the interaction between the subbasins, whereas equation $4 \mathrm{a}$ integrates over the three subbasins and may better account for water moving through the Shallow aquifer under and near the river channel. A plot of flow (fig. 7A) upstream from the Freeman
Diversion (site 22) against release from Lake Piru clearly shows two data populations. The five points grouped on the upper part of the graph are from the five data sets for 1993-95. The two data points on the lower right part of the graph are from two data sets from 1991 , the dry period in which ground-water levels were much lower.

\section{Surface-Water-Quality Measurements}

For all flow measurements, specific conductance was measured in the field. In addition, grab samples were collected and analyzed for sulfate and chloride in the USGS laboratory in San Diego, California, using an ion chromatograph (non-suppressed single column) to separate numerous dissolved ions. Subsequent quantification was by means of conductance and UV absorption. Selected samples were analyzed for stable isotopes of hydrogen and oxygen in the USGS Isotope Fractionization Project in Reston, Virginia, using hydrogen- and $\mathrm{CO}_{2}$-equilibration techniques (see Gonfiatini, 1984, and Coplen, 1994). Techniques used for handling and preserving all surface-water samples are discussed in detail by Izbicki and others (1995). All water-quality data from surface-water samples are given in Appendix 1. Discussion in this section will focus on sulfate and stable-isotope data.

\section{Sulfate}

Changes in sulfate concentration along the river can provide information on stream/ground-water interaction because the native ground water generally has high sulfate concentrations relative to those of local precipitation and runoff. Concentrations in samples collected from USGS monitoring wells ranged from 270 to $680 \mathrm{mg} / \mathrm{L}$. In many other wells in the Santa Clara subbasins, sulfate concentrations are greater than $500 \mathrm{mg} / \mathrm{L}$ (see Izbicki and others, 1995). Izbicki (USGS, written commun., 1997) suggests that these high sulfate concentrations could be due to dry-period accumulation and subsequent wet-period dissolution of sulfate in evaporite minerals. Runoff from the adjacent mountains tends to have lower sulfate concentrations. For example, concentrations in all samples from Santa Paula Creek, site 18, were less than $220 \mathrm{mg} / \mathrm{L}$ (see Appendix 1). Increases in flow owing to ground-water discharge can therefore be distinguished from increases owing to tributary inflow. Care must be taken, however, because some higher values of sulfate 
concentrations have been measured in small tributaries at the lowermost end of the Santa Paula subbasin (Peter Dal Pozzo, UWCD, written commun., 1997).

Sulfate concentrations for samples collected during each of the eight flow-measurement periods for sites on Piru Creek and the Santa Clara River between Lake Piru (site 6) and the Freeman Diversion (site 22) are shown in figures $3 A-H$. Sulfate concentrations for all sites are given in Appendix 1.

With the exception of the July 25-August 2, 1994, data set (fig. $3 E$ ), sulfate concentrations generally increase between the lower part of the Piru subbasin (site 10) and the upper part of the Fillmore subbasin (site 11). Sulfate concentrations also appear to be higher at the lower end of the Fillmore subbasin (site 19) and at the upper end of the Santa Paula subbasin (site 20). As noted previously in the discussion of the flow measurements, the increasing sulfate concentrations at the lower ends of the Piru and Fillmore subbasins are consistent with discharge of high-sulfate ground water at the downstream narrows of each subbasin. The relatively constant sulfate concentrations in the Santa Paula subbasin between sites 20 and 22 (see figure 3 ) indicate that the measured flow increases in this reach do not result from highsulfate ground-water discharge or from low-sulfate local runoff. It is possible that these flow increases are due to discharge of ground water with moderate sulfate concentrations ( 400 to $500 \mathrm{mg} / \mathrm{L}$ ), similar to those measured in USGS monitoring well SP1-5 (3N21W $-15 G 5)$ in the Shallow aquifer near the river.

For the two zero-release data sets, (figs. $3 A, E$ ), a decrease in sulfate concentration occurs between sites 12 and 14 in the Fillmore subbasin, likely reflecting discharge of low-sulfate, shallow ground water associated with Sespe Creek. Similarly, all data sets with measurements at both sites 19 and 20 (figs. $3 A, C$, $D, E$, and $H$ ) show decreases in sulfate concentration between the sites, possibly owing to discharge of lowsulfate, shallow ground water associated with Santa Paula Creek.

As mentioned previously, Densmore and others (1992) measured discharge and sulfate concentrations during base flow at the lower end of the Fillmore subbasin. Using mass-balance computations, they concluded that there seemed to be an increase in ground-water discharge during the release. Similar mass-balance computations were made in this study for both 1993 and 1994 releases to determine if groundwater discharge increased in the Piru and Fillmore
Narrows during releases. Computations were made at the sites with the most consistently high sulfate concentrations: site 11 at the upper end of the Fillmore subbasin and site 19 at the lower end of the Fillmore subbasin. For site 11, the mass-balance computations both overestimate and underestimate the sulfate concentrations. For site 19, the sulfate concentrations during August 30-September 15, 1993, and October $26-30,1993$, releases were slightly higher ( 3 percent and 4 percent) than concentrations from mass-balance computations. No measurement was made during the September 19-24, 1994, period. Because of the small differences for site 19 and the inconsistencies for site 11 , the possibility of increased ground-water discharge at the Piru and Fillmore Narrows resulting from releases (and the associated increased upstream recharge) during this period can not be confirmed.

In addition to the "snapshot" measurement of flow and concentration made by the USGS, the UWCD collected more-frequent samples of the diverted water from the Freeman Diversion (site 22); these samples were analyzed by the USGS for chloride and sulfate. Temporal trends in sulfate and chloride concentration (fig. 8) show that there is an inverse relation between flow measured at the gage at the intake of Freeman Diversion and both sulfate and chloride concentrations; the highest concentrations occur during low flows. As was noted by Densmore and others (1992), ground water, which is higher in sulfate and chloride concentrations than is local runoff, contributes a higher percentage of the flow in the Santa Clara River at the Freeman Diversion at lower flow rates.

Sulfate concentration was measured at several sites that are not shown in figure 3: sites 1-3, upstream from the confluence of Piru Creek and the Santa Clara River; sites 17 and 18 on Santa Paula Creek; and site 23, downstream from the Freeman Diversion. These results are given in Appendix 1. Sulfate concentrations increased between sites 1 and 3 . The reason for this increase in sulfate concentration is not certain. One possible explanation is return flow of pumped ground water. The flow measurements given in Appendix 1 consistently show a net decrease in flow between sites 1 and 3 (decreasing flow between sites 1 and 2, and a slight increase between sites 2 and 3 ) and no remaining flow at site 4 . Note that there is a known, but unmeasured, diversion upstream from site 2. Also shown in Appendix 1 is the previously noted low sulfate concentration at site 18 on Santa Paula Creek, slightly higher values downstream at site 17 , and 

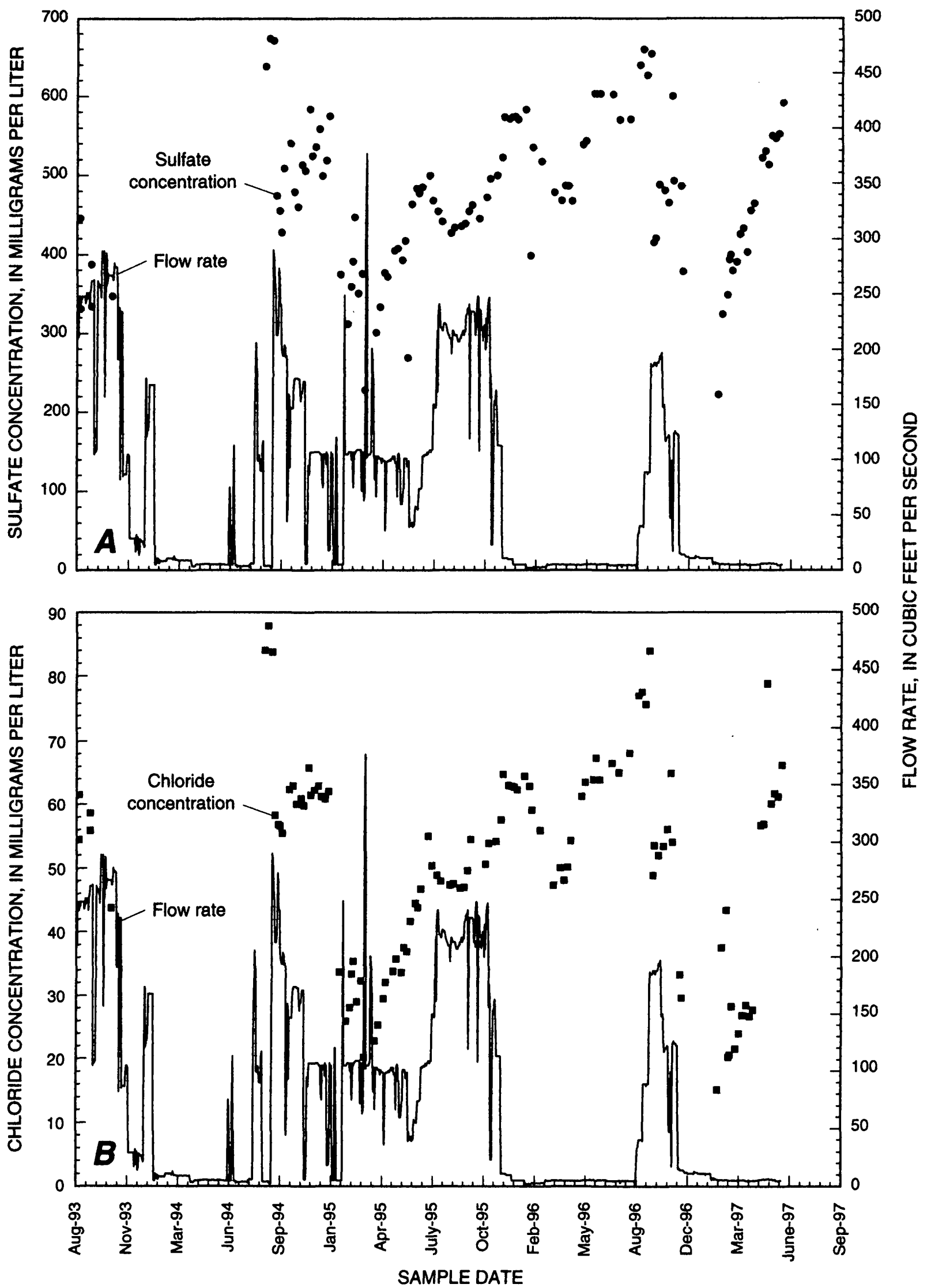

Figure 8. Sulfate concentration and flow rate (A), and chloride cincentration and flow rate (B), at the Freeman Diversion (site 22), 1993-97, Santa Clara River basin, Ventura County, California. 


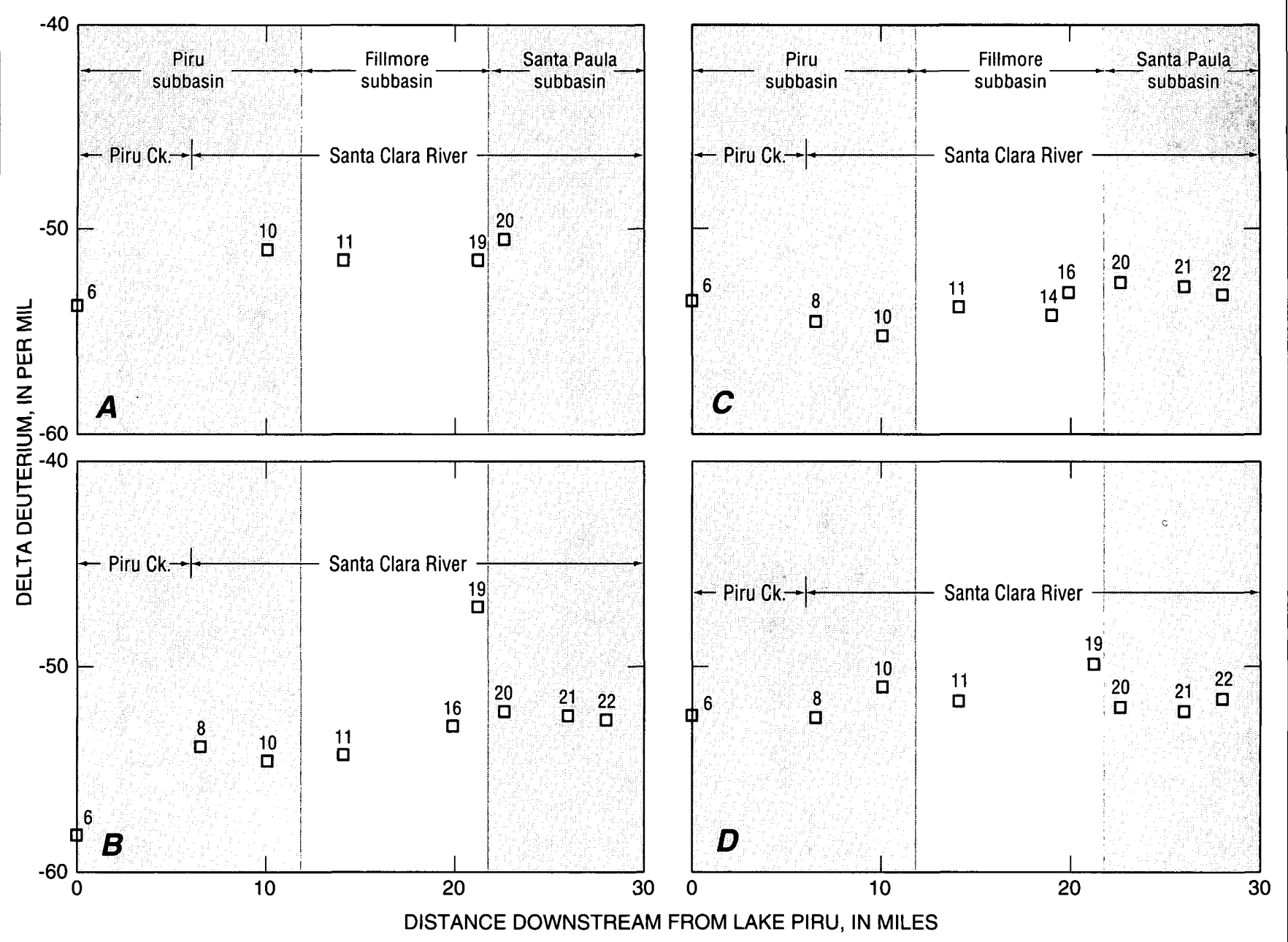

Figure 9. Delta deuterium $(\delta D)$ composition at surface-water monitoring sites in the Santa Clara River basin, Ventura County, California. $\boldsymbol{A}$, August 15-20, 1993; B, October 26-30, 1993; C, September 19-24, 1994; D, October 10-13, 1995.

extremely high sulfate concentrations for the very low flows sampled at site 23, downstream from the Freeman Diversion.

\section{Stable Isotopes of Hydrogen and Oxygen}

Oxygen-18 and deuterium are stable isotopes of oxygen and hydrogen. These isotopes are heavier than the common oxygen- 16 and hydrogen isotopes. The isotopic composition of water is generally expressed in terms of per mil (parts per thousand) differences from the composition of ocean water. These differences are referred to as "delta oxygen- 18 " $\left(\delta^{18} \mathrm{O}\right)$ and "deltadeuterium" $(\delta \mathrm{D})$. Water that has less deuterium than does ocean water will have a negative $\delta \mathrm{D}$ value. Various factors can produce different isotopic signatures in water (see Mazor, 1991; Gat and Gonfiantini, 1981). For example, water that originated as precipitation at higher altitudes or at cooler temperatures would tend to be isotopically lighter (more negative).

Shown in figures $9 A-D$ are the $\delta \mathrm{D}$ values for selected river sites for four of the sampling periods. As can be seen in figure 9 and Appendix 1, most of the samples from the Santa Clara River and from Piru Creek have $\delta \mathrm{D}$ values of -52 to -58 per mil. The $\delta^{18} \mathrm{O}$ values during the release sampling periods were lighter (generally -7 per mil and lighter) than the $\delta^{18} \mathrm{O}$ values measured during the 1991 sampling described by Densmore and others (1992) (heavier than -7 per mil in the Piru and Fillmore subbasins). This difference indicates that water in the reservoir in 1993-95 apparently underwent less evaporation than in 1991, a drought year. Only one set of $\delta \mathrm{D}$ and $\delta^{18} \mathrm{O}$ analyses were made during a zero-release period: August 15-20, 


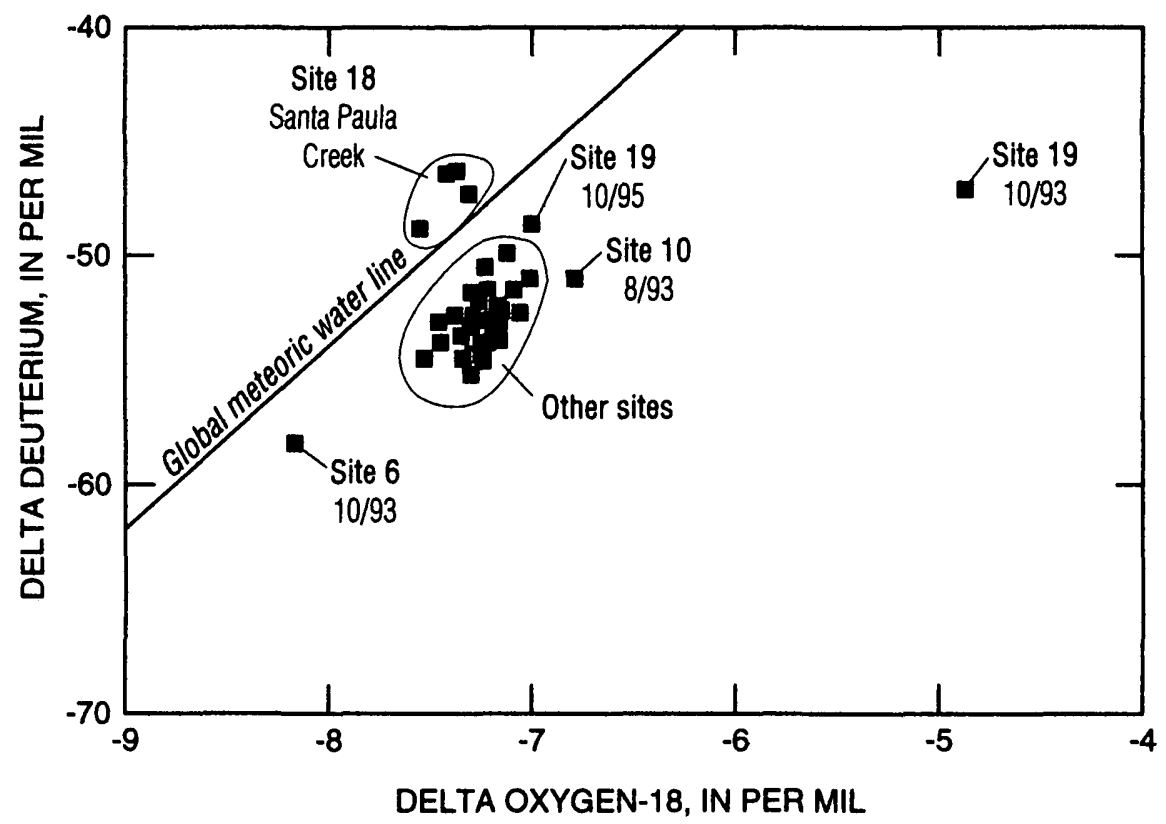

Figure 10. Delta deuterium $(\delta D)$ as function of delta oxygen-18 $\left(\delta^{18} 0\right)$ in surface water, Santa Clara River basin, Ventura County, California.

1993. (fig $9 A$ ). Comparison of the $\delta \mathrm{D}$ values for that period with those during the subsequent release period, October 26-30, 1993 (fig. 9B), indicates that $\delta \mathrm{D}$ values were lighter (more negative) during the release. Note that the $\delta D$ value of the release water (site 6 ) shown in fig. $9 B$ is the lightest of all the surface-water values. The $\delta \mathrm{D}$ data also provide some evidence of heavier (less negative) water at the lower end of the Fillmore subbasin (sites 16 and 19).

Because most precipitation originates from evaporation of seawater, the $\delta^{18} \mathrm{O}$ and $\delta \mathrm{D}$ values of precipitation are linearly correlated and can be plotted along a line called the meteoric water line (fig. 10) (see Izbicki, 1996; Mazor, 1991). As one moves up the meteoric water line, one moves from lighter water (more negative $\delta^{18} \mathrm{O}$ and $\delta \mathrm{D}$ values) to heavier water (less negative $\delta^{18} \mathrm{O}$ and $\delta \mathrm{D}$ values). The isotopic composition of samples relative to each other and to the meteoric water line provides information on source and evaporative history of the water. In figure 10 , the $\delta \mathrm{D}$ values are plotted against the $\delta^{18} \mathrm{O}$ values for surface water in the Santa Clara River subbasins, along with the global meteoric water line. All the values, except those from Santa Paula Creek (site 18) fall below the global meteoric water line, apparently along a regional meteoric water line. Water from Santa Paula Creek (site 18 ), which has $\delta D$ values ranging from -49 to -46 per $\mathrm{mil}$ and $\delta^{18} \mathrm{O}$ values ranging from -7.6 to -7.3 per mil (see Appendix 1), lies above the meteoric line. This water originates as local precipitation or local runoff at lower altitudes than those at which the water in Lake Piru originated and is therefore isotopically heavier (less negative).

\section{ANALYSIS OF GROUND-WATER DATA}

In order to better characterize the interaction of surface water and ground water along the Santa Clara River, three multiple-well monitoring sites were completed in the Santa Paula and Piru subbasins (see figure 1) as part of this study. In this section, data collected from these three sites are summarized. Information is presented on the construction and lithology of the sites, hydraulic-conductivity estimates, the relation of ground-water levels to stream stage, and water quality. Also presented are water-quality data collected from existing wells in the study area as part of the USGS RASA study.

\section{Description of USGS Multiple-Well Monitoring Sites}

The location of the three USGS multiple-well monitoring sites is shown in figure 1. Sites SP1 and 
SP2 are located at the upstream end of the Santa Paula subbasin: SP1 is adjacent to the river (approximately $300 \mathrm{ft}$ from the main channel) and SP2 is

approximately $4,000 \mathrm{ft}$ west of the river. Site RP1 is in the upper part of the Piru subbasin, about $8,000 \mathrm{ft}$ downstream from the confluence of Piru Creek and the Santa Clara River. The geophysical logs, lithologic descriptions, and well-construction diagrams for the monitoring sites are shown in figures 11-13. The determination of which aquifer is tapped by each well was based on lithologic and geophysical data, along with other data analyzed as part of the USGS RASA study.

Site SP1 consists of five separate 2-inchdiameter polyvinyl chloride (PVC) wells installed with perforations at the following intervals below land surface: (1) $660-680 \mathrm{ft}$, (2) $520-540 \mathrm{ft}$, (3) $370-390 \mathrm{ft}$, (4) 260-280 ft, and (5) 60-80 ft (see figure 11). A zone of gravel and gravelly sand, the Shallow aquifer, is present in the upper $90 \mathrm{ft}$ of the well (SP1-5 is perforated in this zone). This coarse zone is underlain by approximately $120 \mathrm{ft}$ of clay. Below the clay, from approximately $230 \mathrm{ft}$ to $400 \mathrm{ft}$, is a second zone of predominantly coarse materials, which is the Mugu aquifer (wells SP1-3 and SP1-4 are perforated in the lower and upper parts, respectively, of this zone). Below $400 \mathrm{ft}$ is the upper Hueneme aquifer. Well SP1-2 is perforated in a coarse zone, indicated by the driller's $\log$ and the resistivity logs, that extends from 460 to $540 \mathrm{ft}$ below land surface. Well SP1-1 is perforated in the lowermost zone of the monitoring site ( $540 \mathrm{ft}$ to $700 \mathrm{ft}$ ); on the basis of the driller's log and the geophysical logs, this zone consists of intervals of moderately coarse materials separated by thin clay layers. Note that the Oxnard aquifer, which normally is present between the Shallow aquifer and the Mugu aquifer (table 1), is not present at this site.

During the drilling of SP1, a 3-foot core was taken (from 131 to $134 \mathrm{ft}$ below land surface) within the thick clay zone (which extends from $100 \mathrm{ft}$ to $220 \mathrm{ft}$ below land surface) below well SP1-4 and above well SP1-5. To help determine the depositional environment of this clay zone, water extracted from the core was analyzed for its strontium $87-86\left({ }^{87} \mathrm{Sr} /{ }^{86} \mathrm{Sr}\right)$ ratio, which was determined to be 0.70956 . As discussed by Izbicki and others (1994), the ${ }^{87} \mathrm{Sr} /{ }^{86} \mathrm{Sr}$ ratio of ground water in the Santa Clara-Calleguas Hydrologic Unit appears to approximate the average ${ }^{87} \mathrm{Sr} /{ }^{86} \mathrm{Sr}$ ratio of the sediment within which the water is found. Izbicki and others (1994) noted that the Santa
Clara River watershed is underlain by rocks of Precambrian age in which ${ }^{87} \mathrm{Sr} /{ }^{86} \mathrm{Sr}$ is greater than the value that they report for current seawater (0.70912). Water in wells completed in Santa Clara River alluvial deposits have ${ }^{87} \mathrm{Sr} /{ }^{86} \mathrm{Sr}$ ratios of 0.710 or greater and thus is clearly different from the water extracted from the core. The lower ${ }^{87} \mathrm{Sr} /{ }^{86} \mathrm{Sr}$ value in the water sampled from the core may indicate that the source material and age of the clay are different from those of the overlying and underlying alluvial materials. Alternatively, the lower ${ }^{87} \mathrm{Sr} /{ }^{86} \mathrm{Sr}$ value in the water sampled from the core may simply reflect the lower permeability of the clay deposits and the longer residence time of the water that they contain. The longer residence time would allow the water to come closer to equilibrium with the sediment. In order to more fully assess the implications of these ${ }^{87} \mathrm{Sr} /{ }^{86} \mathrm{Sr}$ results from the core, it would be necessary to determine the ${ }^{87} \mathrm{Sr} /{ }^{86} \mathrm{Sr}$ values in the sediment itself (Robert Fleck, USGS, oral commun., 1997).

Monitoring-site SP2, approximately $4,000 \mathrm{ft}$ west of site SP1 (see figure 1) consists of four 2-inch PVC wells perforated at the following intervals: (1) $530-550 \mathrm{ft}$, (2) $290-310 \mathrm{ft}$, (3) $150-170 \mathrm{ft}$, and (4) 60-70 ft (see figure 12). The upper $100 \mathrm{ft}$, the Shallow aquifer, is predominantly clay but includes several thin coarse zones; well SP2-4 is perforated in the thickest of these zones. Below the Shallow aquifer, from $100 \mathrm{ft}$ to $260 \mathrm{ft}$, is the Oxnard aquifer, in which well SP2-3 is perforated. The Mugu aquifer, which extends from $260 \mathrm{ft}$ to $350 \mathrm{ft}$ below land surface, is composed of materials that are somewhat finer grained than those of the overlying Oxnard aquifer; well SP2-2 is perforated in this zone. Below $350 \mathrm{ft}$ is the upper Hueneme aquifer; well SP2-1 is perforated in this zone.

Monitoring-site RP1 is located in the Piru subbasin, adjacent to the river, about $8,000 \mathrm{ft}$ downstream from the confluence of Piru Creek and the Santa Clara River (see figure 1). Five wells were installed at the following intervals below land surface: (1) $590-610 \mathrm{ft}$, (2) $310-330 \mathrm{ft}$, (3) $220-240 \mathrm{ft}$, (4) $140-160 \mathrm{ft}$, and (5) 50-70 ft (see figure 13). No welldefined clay zones were identified. The entire upper $540 \mathrm{ft}$ is coarse material (gravelly sand). The driller's $\log$ and the geophysical logs indicate that the upper $70 \mathrm{ft}$, the Shallow aquifer, is coarse and contains considerable gravel; well RP1-5 is perforated in this zone. The underlying Oxnard aquifer, which extends to a depth of approximately $180 \mathrm{ft}$, is coarse and also contains considerable gravel; well RP1-4 is perforated 


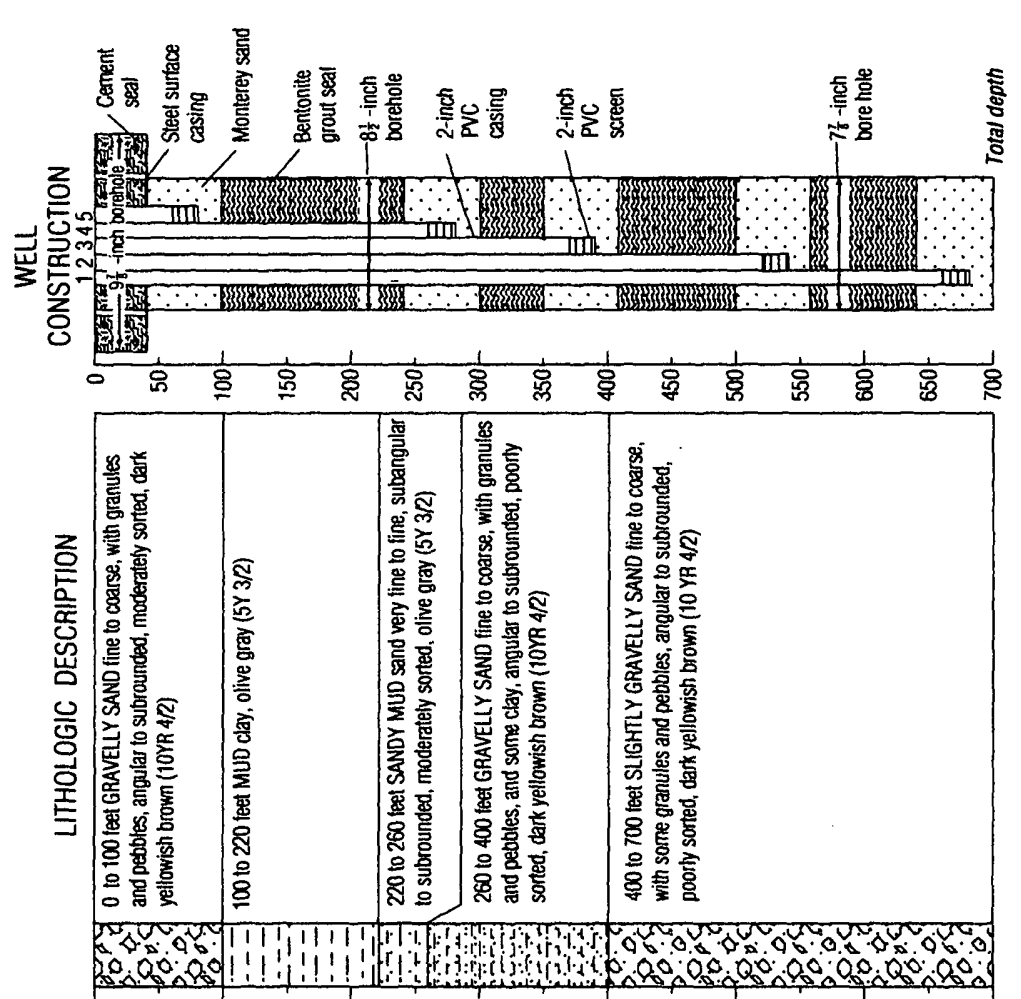

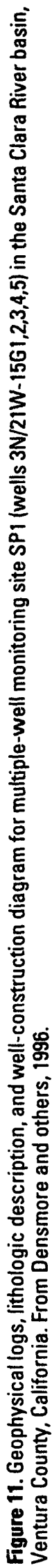



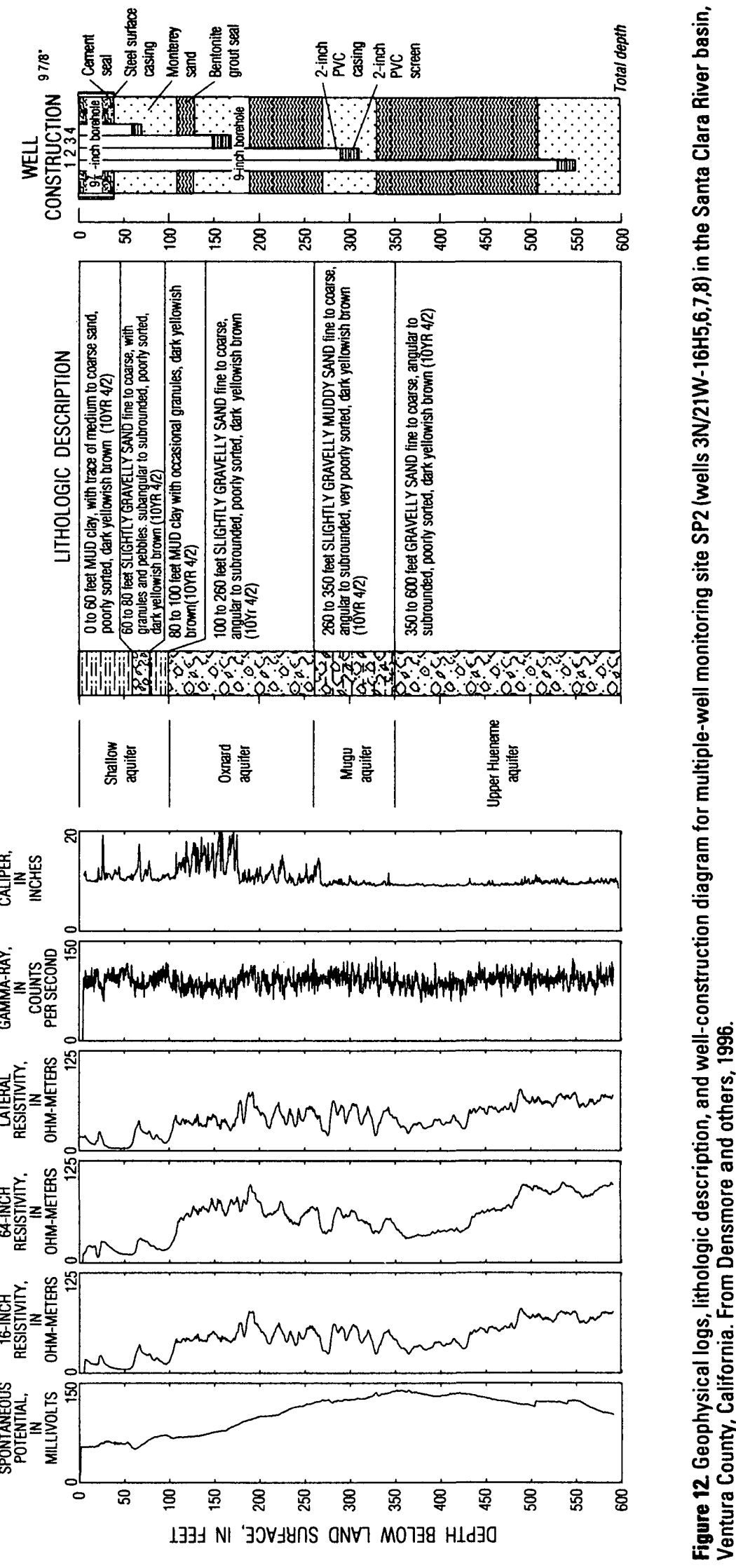

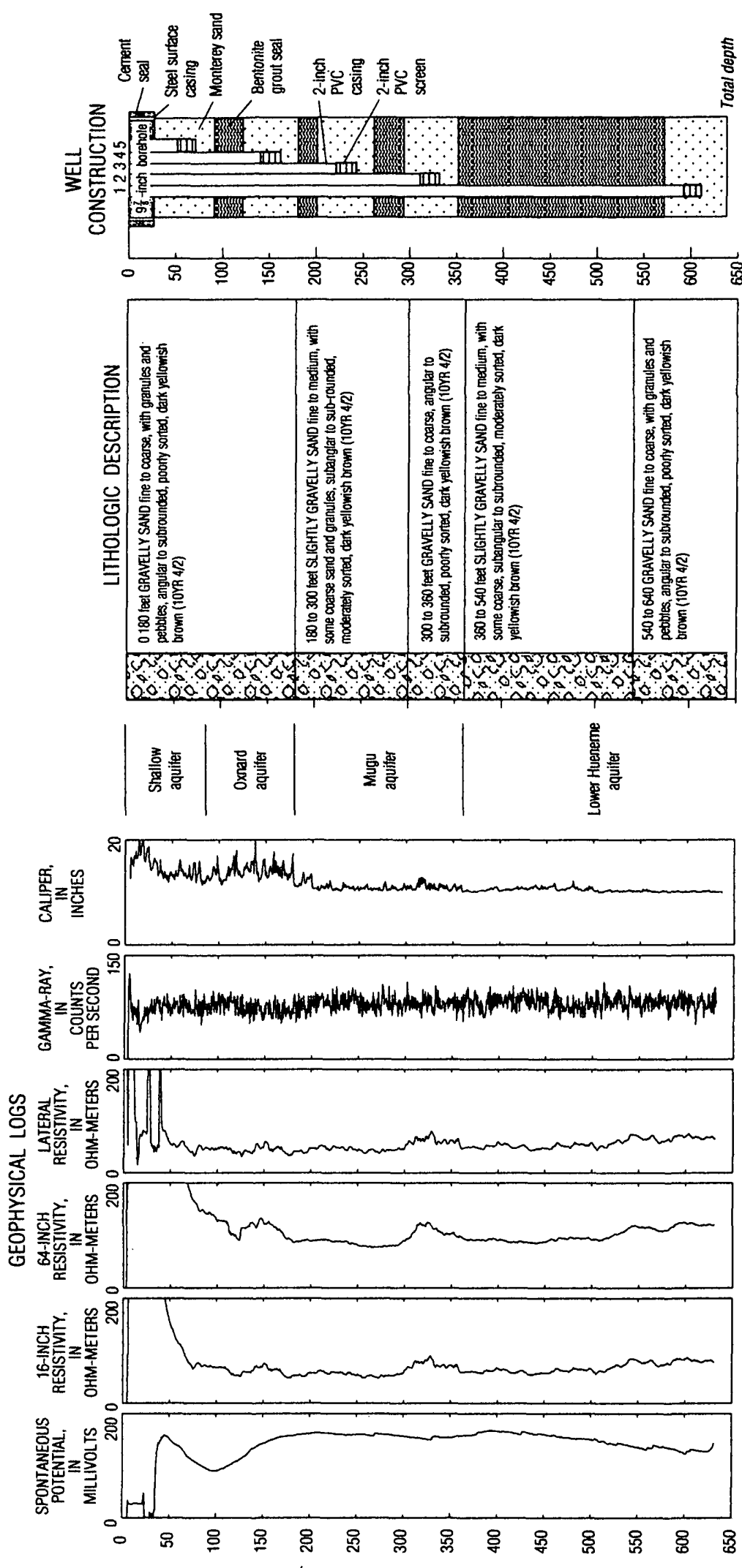
in this zone. The Mugu aquifer extends from $180 \mathrm{ft}$ to $360 \mathrm{ft}$ below land surface; wells RP1-2 and RP1-3 are perforated in the lower and upper parts, respectively, of this zone. The lower Hueneme aquifer begins at a depth of approximately $360 \mathrm{ft}$ below land surface; well RP-1 taps this zone. The upper Hueneme aquifer, which is normally present below the Mugu aquifer, is not present at this site. The upper part of the San Pedro Formation was either eroded or never deposited at this location. On the basis of drilling times and geophysical logs at this site, the materials of the lower Hueneme aquifer are more consolidated than the materials in the overlying aquifers.

\section{Hydraulic-Conductivity Estimates}

Slug tests were done at the three multiplecompletion monitoring sites in order to help quantify geohydrologic properties affecting the interaction of ground water and surface water and to provide information for the regional ground-water modeling conducted as part of the USGS RASA program. At least one and as many as eight tests were done for each of the 14 wells, and the results are given in Appendix 3. Data from all wells except RP1-1 and SP2-4 were analyzed using the method of Kipp (1985); data from RP1-1 and SP2-4 were analyzed using the method of Cooper and others (1967). As pointed out by Cooper and others (1967), estimates of storage coefficient(S) from slug-test data are problematic because the determined value of $S$ is extremely sensitive to the choice of the matching type curve. Therefore, hydraulic conductivities were estimated for two specified values of specific storage (1.0E-4 and 1.0E-6). As shown in Appendix 3, geometric mean estimates of hydraulic conductivity in the Shallow aquifer were 45,85 , and $35 \mathrm{ft} / \mathrm{d}$ at SP1-5, SP2-4, and RP1-5, respectively. Geometric mean estimates of hydraulic conductivity in the Oxnard aquifer were 100 and $33 \mathrm{ft} / \mathrm{d}$ in SP2 -3 and RP1-4, respectively. Geometric mean estimates of hydraulic conductivity in the Mugu aquifer were $68,18,26,17$, and $30 \mathrm{ft} / \mathrm{d}$ in SP1-3, SP1-4, SP2-2, RP1-2, and RP1-3, respectively. Geometric mean estimates of hydraulic conductivity in the upper Hueneme aquifer were 58, 15, and $24 \mathrm{ft} / \mathrm{d}$ in SP1-1, SP1-2, and SP2-1, respectively. The geometric mean estimate of hydraulic conductivity in the lower Hueneme aquifer was $7 \mathrm{ft} / \mathrm{d}$.

\section{Ground-Water Levels and Relation to Stream} Stage

The three multiple-well monitoring sites were instrumented with transducers and data loggers. Transducers were installed in all wells at monitoring sites SP1 and SP2 and in wells RP1-1, RP1-2, and RP1-5 at monitoring site RP1. Water levels for each of three monitoring sites for the period July 1994 to October 1996 are shown in figure 14. Also shown in figure 14 are measured heads in drive points that were installed in the bed of the Santa Clara River near monitoring sites SP1 and RP1. The purpose of these drive points, which also were instrumented with transducers and data loggers, was to provide a quantitative estimate of the changes in stream stage. As shown in figure $14 A$, water levels in SP1-5, the shallowest well, were approximately $15 \mathrm{ft}$ higher and responded very differently than water levels in the four deeper wells. These differences indicate that the thick clay layer at this site acts as a confining zone that limits the hydraulic connection between the Shallow aquifer and the underlying aquifers. Water levels in SP1-5 appear to respond exclusively to changes in stream stage. Water levels in the four deeper wells at SP1 also show a response to changes in stream stage, but appear to be dominated by seasonal pumping patterns.

As at site SP1, water levels in SP2-4, the shallowest well at monitoring site SP2, are consistently higher than those in the three deeper wells (see figure 14A). Unlike at SP1-5, water levels in SP2-4 show a response to seasonal pumping patterns.

At site RP1, all three instrumented wells respond similarly, with water levels in RP1-1 (the deepest well) being slightly lower than those in RP1-2 and RP1-5 (the shallowest well). As described earlier, well RP1-1 was installed in the lower Hueneme aquifer in materials that are more consolidated than those in the overlying aquifers. During the data-collection period, water-level fluctuations in all the RP1 (Piru subbasin) wells were considerably larger than those in the Santa Paula subbasin wells. Recall (fig. 5) that the long-term monitoring well for the Piru subbasin, 4N/18W-29M2, also showed greater amplitude of water-level fluctuations than did the long-term monitoring wells in the Fillmore and Santa Paula subbasins.

Data were collected from the two in-stream drive points for brief periods. The instrumentation at the site near RP1 functioned only intermittently, and it was not possible to complete any quantitative analysis of the stream-aquifer interaction at this location. Ground- 


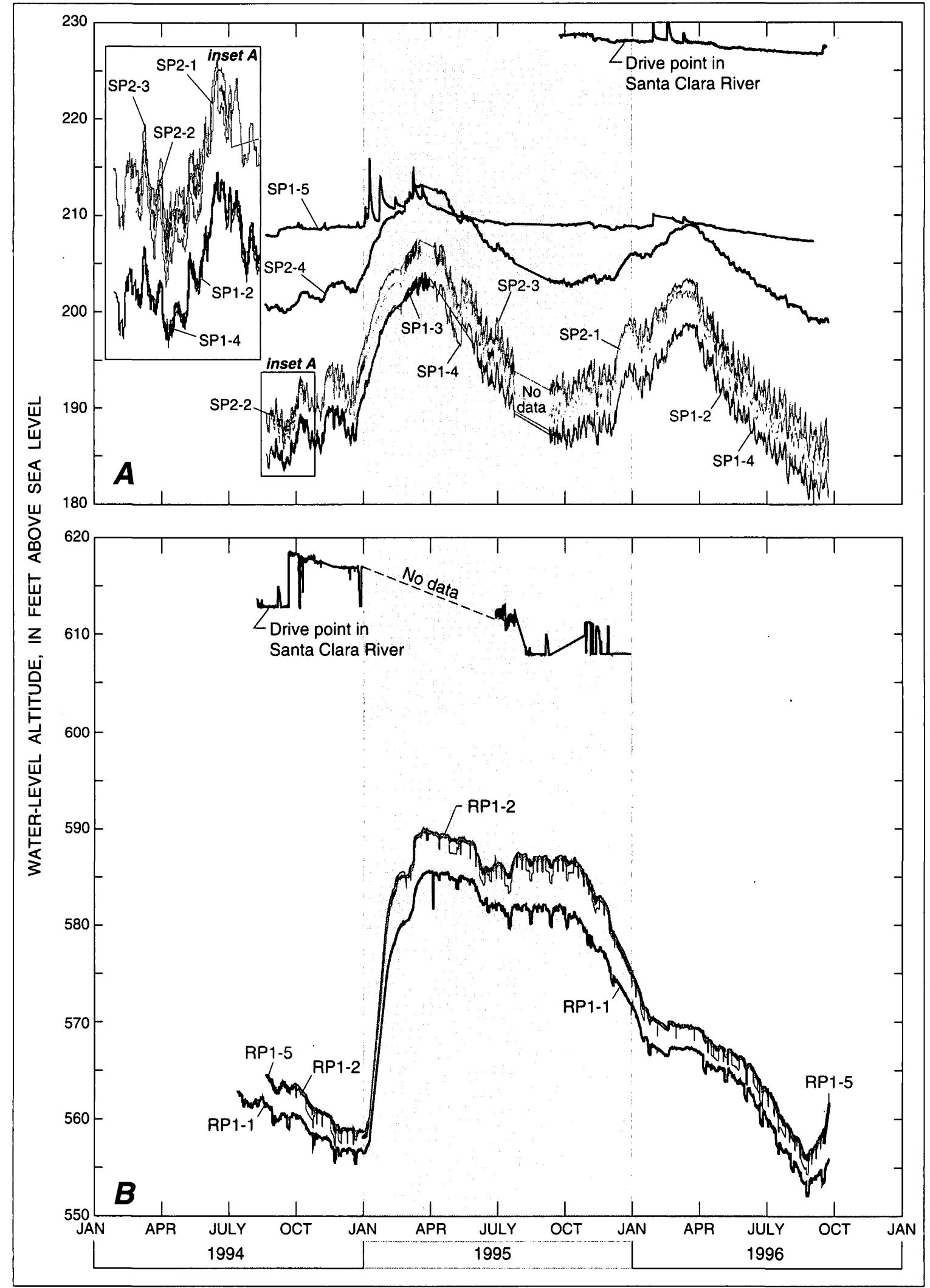

Figure 14. Water level in drive points in the Santa Clara River and in monitoring wells at sites SP1 and SP2 (A), and at site RP1 (B), 1994-96, Santa Clara River basin, Ventura County, California. 
water-level data for well SP1-5 and the water-level data from the adjacent in-stream drive point were analyzed using an analytic model recently developed by Barlow and Moench (1998). The model, based on the assumption of a semi-infinite, water-table aquifer bounded by a fully penetrating river, considers twodimensional, cross-sectional flow and uses the convolution technique to predict ground-water-level fluctuations caused by a continuously varying river stage. The model uses a Laplace transform solution for a problem similar to that solved by Neuman (1981, eqs. $1-6)$, with the additional consideration of a semipervious streambank.

The model was applied to data from SP1-5 and the in-stream drive point for an 8-day storm period in March 1996. Although not all the assumptions of the analytic model are met for these data, the analyses yielded some potentially useful preliminary results. The best match between measured and calculated ground-water levels was found for the following set of parameters: horizontal hydraulic conductivity $(\mathrm{Kx})$ of $60 \mathrm{ft} / \mathrm{d}$, vertical conductivity $(\mathrm{Kz})$ of $6 \mathrm{ft} / \mathrm{d}$, specific storage (Ss) of $1.0 \mathrm{E}-05 / \mathrm{ft}$, and a specific yield of 0.01-0.02 (Paul Barlow, USGS, written commun., 1997). A streambed leakance value of 0.011 (which represents a 1 -foot-thick streambed with a hydraulic conductivity of $6 \mathrm{ft} / \mathrm{d}$ ) was used. The calculated waterlevel response was very sensitive to the specific-yield value and the $\mathrm{Kz} / \mathrm{Kx}$ ratio. The rapid response of water levels in SP1-5 indicates good hydraulic connection between the river and the aquifer over relatively large horizontal distances $(300 \mathrm{ft})$ and suggests that the assumption of a fully penetrating river may be appropriate for this analysis. The $\mathrm{Kz} / \mathrm{Kx}$ ratio of 0.1 indicates substantial anisotrophy. The low estimated value for specific yield would suggest that the system is locally confined. This result is surprising, given the absence of clay in materials encountered when drilling the upper $90 \mathrm{ft}$ of SP1 (see figure 11); the low value may indicate the possible presence of a shallow confining layer(s) immediately beneath the river.

\section{Ground-Water-Quality Measurements}

Water-quality samples were collected and analyzed from the three USGS multiple-completion monitoring sites (see Appendix 4). The results from these analyses, along with relevant ground-waterquality data collected as part of the southern California RASA (Izbicki and others, 1995), are presented below.
Emphasis is on sulfate, the stable isotopes of hydrogen and oxygen, tritium, and carbon-14. The methods used for sample collection, handling, preservation, and analysis are described in detail by Izbicki and others (1995). Construction information for the USGS wells is shown in figures 11-13. Construction information for the non-USGS wells is given in Appendix 5.

\section{Sulfate}

Sulfate concentrations (fig. 15; App. 4) in the study area generally ranged from 400 to $600 \mathrm{mg} / \mathrm{L}$, although some concentrations were as high as 1,000 $\mathrm{mg} / \mathrm{L}$. As was described in the sections on surfacewater data, sulfate concentrations provide an indicator of sources of discharge to the Santa Clara River. There are several interesting aspects of the sulfate results for the USGS ground-water monitoring sites. First, the sulfate concentration in the water extracted from the core in the upper clay zone in SP1 was $3,000 \mathrm{mg} / \mathrm{L}$ (see Appendix 4), indicating that this zone is a possible source of the generally high sulfate concentrations in ground water. Second, as suggested in the section "Analysis of Surface-Water Data," increases in streamflow in the lower part of the Santa Paula subbasin may be due to discharge of ground water from the Shallow aquifer, in which sulfate concentrations (well SP1-5, for example) are similar to that in the river. Third, sulfate concentrations for the three shallowest wells at the RP1 site (RP1-3, RP1-4, and RP1-5) are among the lowest in the study area, apparently reflecting the effects of regular recharge from the Santa Clara River.

\section{Stable Isotopes of Hydrogen and Oxygen}

Delta deuterium $(\delta \mathrm{D})$ and delta oxygen-18 $\left(\delta^{18} \mathrm{O}\right)$ values in samples from selected wells in the study area are shown on the map in figure 16. Izbicki (1996, fig. 4) presents $\delta \mathrm{D}$ values for the entire Santa Clara-Calleguas Hydrologic Unit. According to Izbicki, $\delta \mathrm{D}$ values in water from most wells in the Santa Clara Valley are less (more negative) than -50 per mil, indicating that the water in these wells was recharged by the Santa Clara River. As can be seen in figure 16 , wells with $\delta \mathrm{D}$ values greater (less negative) than -50 per mil (including SP2-1, the deepest well at monitoring site SP2) tend to be north of the river in the Santa Paula and lower Fillmore subbasins; these heavier $\delta \mathrm{D}$ values reflect recharge from local runoff from the lower altitude mountains to the north. 




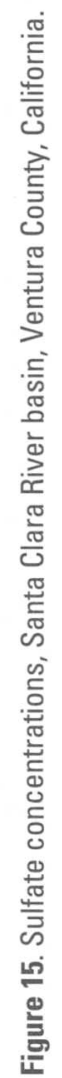




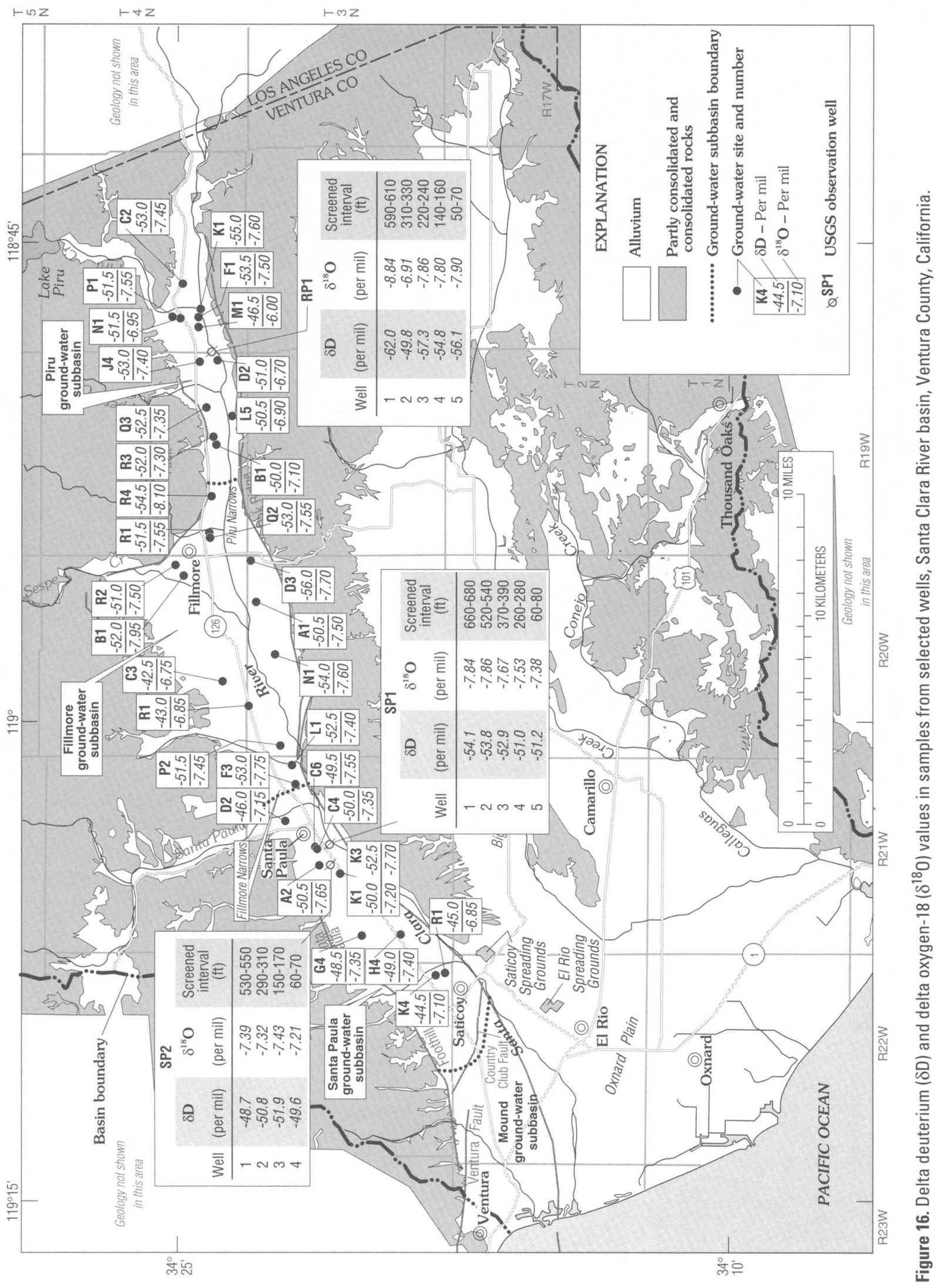




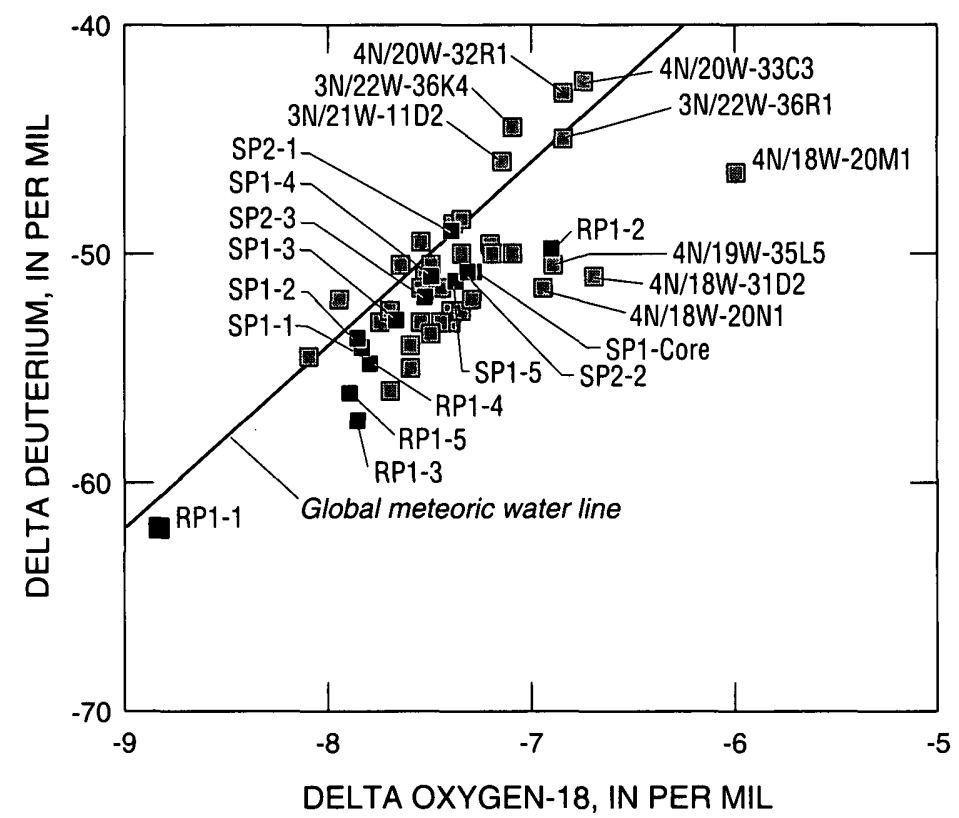

Figure 17. Delta deuterium $(\delta D)$ as a function of delta oxygen-18 $\left(\delta^{18} 0\right)$ in water from wells, Santa Clara River basin, Ventura County, California.

A plot of $\delta \mathrm{D}$ as a function of $\delta^{18} \mathrm{O}$ for groundwater samples in the Piru, Fillmore, and Santa Paula subbasins is shown in figure 17. This figure is analogous to figure 10 , which is a plot of $\delta \mathrm{D}$ as a function of $\delta^{18} \mathrm{O}$ in surface-water samples. As shown in figure 17, samples from most wells in the area, including most of the USGS monitoring wells, plot below the global meteoric water line, in a manner similar to that of samples from the Santa Clara River (see figure 10). Again, all wells with $\delta \mathrm{D}$ and $\delta^{18} \mathrm{O}$ values that plot on or above the meteoric water line-including SP2-1, the deepest well at monitoring site SP2 - are north of the Santa Clara River in the Santa Paula and lower Fillmore subbasins. Water from the core taken from the upper clay zone at monitoring site SP1 has an isotopic signature (fig. 17) very similar to that of water from the wells that are perforated above (SP1-5) and below the clay (SP1-4).

The $\delta^{18} \mathrm{O}$ and $\delta \mathrm{D}$ data plotted in figure 17 also indicate that there are three different isotopic signatures in samples from monitoring site RP1. Water from well RP1-1, which is perforated in the lower Hueneme aquifer, is the lightest (most negative) of all the ground-water samples. Water from wells RP1-3, RP1-4, and RP1-5 is somewhat heavier (less negative). Water from well RP1-2, perforated in the basal zone of the Mugu aquifer, is the heaviest of the samples from the 14 wells in the USGS monitoring sites (in terms of $\delta^{18} \mathrm{O}$ ). As can be seen by comparing figures 17 and 9 , the sample from the Santa Clara River at site 10 during zero-release conditions, August 15-20, 1993, has an isotopic signature similar to that of RP1-2. This suggests that the discharging ground water at the Piru Narrows may include water from this permeable basal zone. Samples from several other Piru subbasin wells that appear to draw water from the same interval as RP1-2 have a similar isotopic signature (fig. 17). These other wells include $4 \mathrm{~N} / 18 \mathrm{~W}-20 \mathrm{~N} 1$ (perforated from $220 \mathrm{ft}$ to $441 \mathrm{ft}$ ), $4 \mathrm{~N} / 18 \mathrm{~W}-31 \mathrm{D} 2$ (perforated from 220 $\mathrm{ft}$ to $500 \mathrm{ft}$, and 4N/19W-35L5 (total depth of $302 \mathrm{ft}$ ). A sample from well 4N/18W-20M1 (total depth of 397 $\mathrm{ft}$ ), which is located very near to RP1, is the heaviest (in terms of $\delta^{18} \mathrm{O}$ ) of all the ground-water samples.

\section{Tritium and Carbon-14}

Tritium, the heavy isotope of hydrogen, can be a useful tool for estimating the age of ground water that was recharged less than about 50 years ago. The atmospheric testing of nuclear weapons released large quantities of tritium into the atmosphere beginning in 1952. As discussed by Izbicki (1996), ground water in the study area in which tritium concentrations are less than the detection limit of 0.3 tritium unit (TU) (referred to as "tritium dead" water) is interpreted as having recharged prior to 1952 . Ground water with tritium concentrations greater than this is interpreted as recharge that occurred after 1952 . As stated by Izbicki (1996) and shown in figure 18, detectable tritium is 


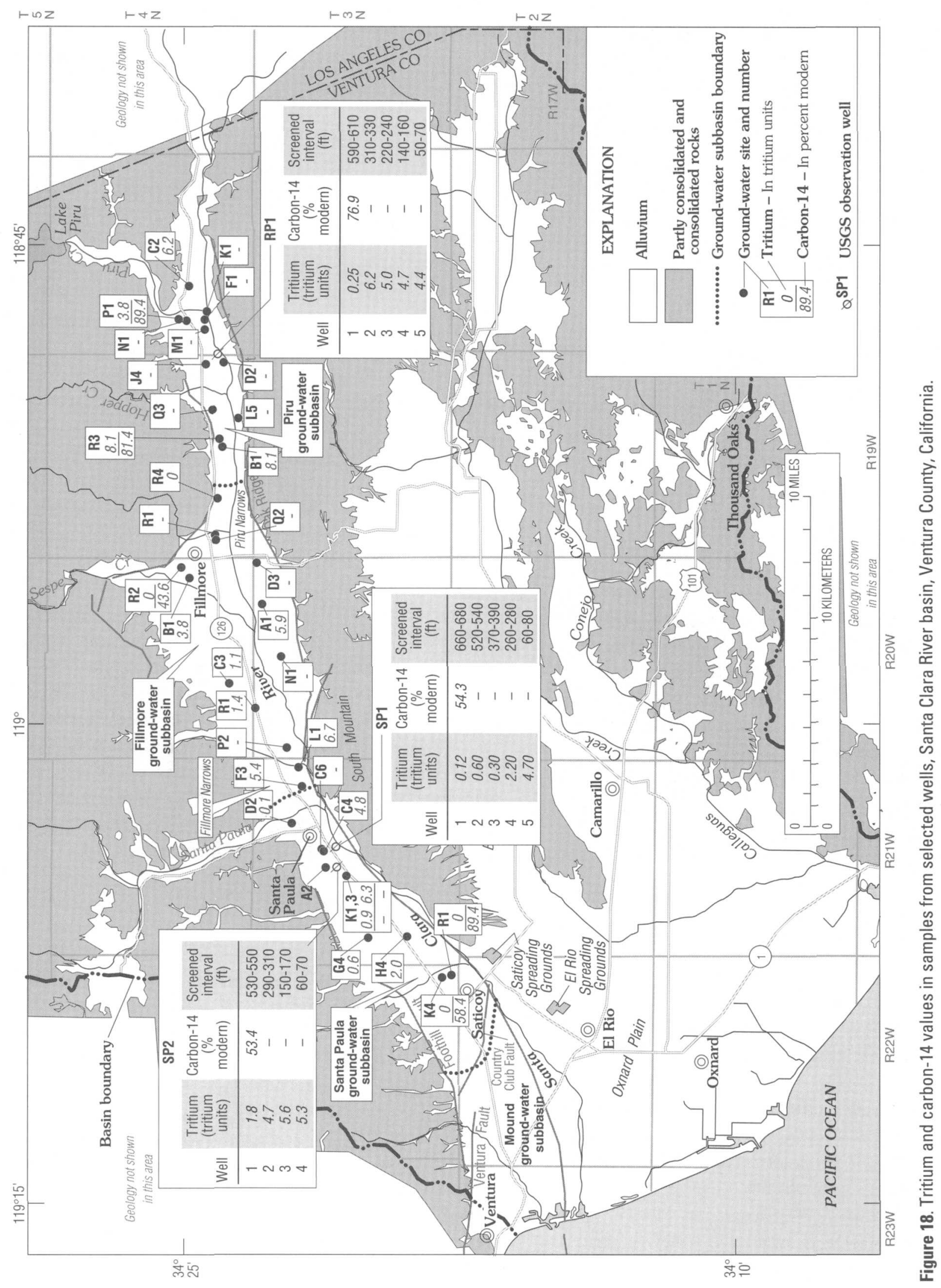


present in samples from most of the sampled wells in the Santa Clara Valley. At the three USGS multiplecompletion monitoring sites, tritium concentrations clearly exceeded the detection limit in 10 of the 14 wells. Samples from the deepest well at RP1 (RP1-1) and the three deepest wells at SP1 (SP1-1, SP1-2, and SP1-3) all had tritium concentrations near or below the detection limit. These four wells apparently have received little recent recharge. As just discussed, RP1-1, which is perforated in the lower Hueneme aquifer, also has a unique isotopic signature (see figure 17). The fact that water from SP1-1, SP1-2, and SP1-3 appears to be "tritium dead" indicates that, even though the monitoring site is located about $300 \mathrm{ft}$ from the Santa Clara River, very little recent river water has reached these lower zones. Apparently, the clay zone (see figure 11) greatly restricts the vertical movement of water from the Shallow aquifer at this location.

Carbon-14 can be a useful tool for estimating the age of older ground water (see Mazor, 1991). Izbicki (1996) describes how carbon-14, together with carbon$13 / 12$ ratios $\left(\delta^{13} \mathrm{C}\right)$, was used to estimate ground-water ages throughout the Santa Clara-Calleguas Hydrologic Unit. Unadjusted carbon-14 values, measured as percent modern carbon, are shown in figure 18. For this study, carbon-14 and $\delta^{13} \mathrm{C}$ values were determined for water from the deepest well in each of the three monitoring sites: SP1-1, SP2-1, and RP1-1. As can be seen from figure 18 and Appendix 4, SP1-1 and SP2-1 have very similar values for carbon-14 (54 percent modern carbon and 53 percent modern carbon, respectively) and for $\delta^{13} \mathrm{C}(-13.4$ and -13.1 , respectively). Using these data, Izbicki (1996) estimated the age of water in these wells to be 300 to 400 years old. The fact that tritium is above the detection limit in water from well SP2-1 (see figure 18) raises the possibility that, although the well was extensively developed by air lifting, this measured tritium may be the result of residual drilling fluids.

Results from the carbon isotope analysis for RP1-1 are 77 percent modern carbon and a $\delta^{13} \mathrm{C}$ value of -0.8 . These values differ considerably from those for water from SP1-1 and SP2-1 and indicate that water in RP1-1 probably is significantly younger (recharged more recently). Another noticeable difference between the RP1 site and the SP1 and SP2 sites is the dissolvedoxygen concentration. All five wells at RP1 have at least one dissolved-oxygen concentration value that is $3 \mathrm{mg} / \mathrm{L}$ or greater (see Appendix 4). In contrast, the dissolved-oxygen concentration in all wells at SP1 and $\mathrm{SP} 2$ was less than $0.5 \mathrm{mg} / \mathrm{L}$. Both the carbon and dissolved-oxygen data seem consistent with the fact that the Piru subbasin is located at the upper end of the flow system where there has been continuous groundwater recharge from the river.

\section{MANAGEMENT IMPLICATIONS OF SURFACE- WATER/GROUND-WATER INTERACTIONS}

The information provided by the surface-water and ground-water data described in this report has potential implications for water management in the area. The repeated measurements of discharge and water quality at different sites along the Santa Clara River and its tributaries, under different releases from Lake Piru and under different antecedent ground-water conditions, allow improved characterization of recharge and (or) discharge processes in different reaches. The simple regressions indicate that it may be possible to estimate net flow losses in individual subbasins on the basis of release rates from Lake Piru and depths to ground water at indicator wells. On a more aggregated scale, it also may be possible to estimate available flow at the Freeman Diversion on the basis of Lake Piru release rates and depths to ground water at indicator wells. These kinds of simple relations could aid water managers in predicting the total flow availability at Freeman Diversion that would result from different Lake Piru release strategies. This information could be useful for identifying strategies that are "most efficient" in terms of transmitting the most Lake Piru water downstream to the Freeman Diversion and, incorporating the inverse relation between flow and sulfate and chloride concentrations (fig. 8), for predicting likely sulfate concentrations at the Freeman Diversion. Because of the small number of observations on which the regressions are based and the multiple sources of error and uncertainty, however, great caution must be taken in drawing implications from the regression results.

Additional data would be required to confirm the apparent relation between net flow changes, Lake Piru release rates, and depths to ground water. Additional data sets at the sampling sites described in this report, along with better quantification of diversions, would be useful. To reduce the potential sources of error and uncertainty, it would be desirable to collect all measurements on a single day during a period of 
constant release from Lake Piru. Continued monitoring of the USGS multiple-completion sites and installation of new monitoring sites in the Fillmore subbasin and in the lower Santa Paula subbasin also would be helpful. These additional data would enable testing of some of the hypotheses presented in this report. Finally, more detailed modeling of the interaction of surface water and ground water could be of value in the study area. As part of the USGS RASA study, a two-layer (representing the upper and lower aquifer systems) ground-water model that incorporates stream routing is being developed (R.T. Hanson, USGS, written commun., 1998). A one-dimensional riverflow and transport model also was developed to model the dyetracer test done as part of this study (Paybins and others, 1998; Nishikawa and others, 1999).

Extending the RASA model to simulate the Shallow aquifer, linking it to the riverflow and transport model, and applying optimization techniques as was done in the Oxnard Plain (Reichard, 1995) could provide improved tools to evaluate water-management scenarios.

\section{SUMMARY AND CONCLUSIONS}

Surface-water-discharge and water-quality data, together with geohydrologic data, were compiled and analyzed in order to gain an improved understanding of the ground-water system and stream-aquifer interactions along the Santa Clara River in Ventura County, California.

During 1993-95, eight sets of discharge and water-quality measurements were made at different locations along the Santa Clara River. Two of the data sets were collected during base flow (zero release from Lake Piru); the remaining data sets were collected during different releases from Lake Piru. The data show consistent decreases in flow in Piru Creek from Lake Piru to the confluence of Piru Creek and the Santa Clara River and in the Santa Clara River from this confluence to the lower part of the Piru subbasin. Flow generally increases between the lower end of the Piru subbasin and the upper end of the Fillmore subbasin. An increase in sulfate concentration indicates that this increase in flow represents discharge of high-sulfate ground water associated with the Piru Narrows. In the Fillmore subbasin, there are consistent increases in flow in the lower part. As in the Piru subbasin, increases in sulfate concentration indicate that the flow increases represent high-sulfate ground-water discharge. Most of the data sets show increasing flow in the lower part of the Santa Paula subbasin. There are no significant increases in sulfate concentration associated with increases in flow in the lower part of the Santa Paula subbasin; the source of this water flux may be the Shallow aquifer near the river. Time-series data for sulfate concentration at the Freeman Diversion illustrate the relation between lower flows and higher sulfate concentrations at the Freeman Diversion: at lower flows, a higher percentage of the downstream flow is from high-sulfate ground-water discharge.

Several regressions were computed in order to statistically analyze the correlation of net flow changes in the individual subbasins with Lake Piru release rates and ground-water conditions. Because these regressions were based on a very small number of data sets, and because of the multiple sources of uncertainty and potential errors in the data, the results must be interpreted very cautiously. Regressions indicate that net flow change in the Piru subbasin can be statistically explained by the quantity released from Lake Piru and depth to ground water at an indicator well. Net flow changes in the Fillmore subbasins are somewhat less well explained by the joint effects of reservoir release and ground-water conditions. For the Fillmore subbasin, the regression coefficient for release from Lake Piru is not statistically significant. Flow changes in the Santa Paula subbasin are not well explained statistically by the Lake Piru release and depth to ground water.

An additional regression was computed to evaluate the joint effects of reservoir release and ground-water conditions on the overall ground-water recharge and discharge summed over all three subbasins. Measured flow in the Santa Clara River upstream from the Freeman Diversion was regressed against release from Lake Piru and depth to ground water at an indicator well. Results indicate that a relation exists between flow at the Freeman Diversion and both reservoir release and ground-water conditions. This relation has potential value for watermanagement decisions, particularly because of the inverse relation between flow at the Freeman Diversion and sulfate concentration.

Ground-water data from USGS multiplecompletion monitoring sites installed during this study and from existing wells were analyzed. Analysis of slug-test data yielded estimates of hydraulic conductivities ranging from 35 to $85 \mathrm{ft} / \mathrm{d}$ in the Shallow 
aquifer, 33 to $100 \mathrm{ft} / \mathrm{d}$ in the Oxnard aquifer, 17 to 68 $\mathrm{ft} / \mathrm{d}$ in the Mugu aquifer, and 15 to $58 \mathrm{ft} / \mathrm{d}$ in the upper Hueneme aquifer, and an estimate of $7 \mathrm{ft} / \mathrm{d}$ in the lower Hueneme aquifer. Analysis of water levels from the USGS wells, together with data from in-stream drive points, provided additional information on streamaquifer relations. At site SP1, water levels in the Shallow aquifer are very closely tied to river stage and show little response to pumping. Water levels in the deeper wells appear to be dominated by pumping. At site RP1, all five wells responded in a similar manner. During the entire data-collection period, water-level fluctuations in all the RP1 (Piru subbasin) wells were larger than those in the Santa Paula subbasin wells. An analytic model of stream-aquifer interaction applied to water-level data from SP1-5 and the in-stream drive point yielded estimates of storage properties and the ratio of vertical to horizontal hydraulic conductivity.

Analysis of ground-water-quality data on the concentrations of sulfates, the stable isotopes of hydrogen and oxygen, tritium, and carbon provided some insight into the ground-water flow system and the interaction between ground water and surface water. Sulfate concentrations in the regional ground-water system generally ranged from 400 to $600 \mathrm{mg} / \mathrm{L}$, although some concentrations were as high as 1,000 $\mathrm{mg} / \mathrm{L}$. Ground water that contains very high concentrations of sulfate appears to be associated with discharge to the river at the Piru and Fillmore Narrows. Ground water from the Shallow aquifer, with moderate sulfate concentrations, may be the source of discharge to the river in the lower part of the Santa Paula subbasin.

Isotopic data provide information on the source and age of water. The $\delta \mathrm{D}$ and $\delta^{18} \mathrm{O}$ data indicate that samples from most wells, including most of the wells at the USGS monitoring sites, have $\delta \mathrm{D}$ values less (more negative) than -50 and plot below the global meteoric water line. The samples with values greater (less negative) than -50 and which plot above the global meteoric water line (SP2-1, the deepest well at monitoring site SP2, for example) probably reflect recharge from local precipitation. Unlike most sampled wells in the study area, the deepest well at site RP1 and the three deepest wells at site SP1 have tritium levels that are near or below the detection limit. The SP1 data indicate little vertical movement of water from the Shallow aquifer to the lower aquifers near the river in the upper Santa Paula subbasin.
The results from this study have potential watermanagement implications. In particular, the suggested correlation of flow losses and flow at the Freeman Diversion with releases from Lake Piru and groundwater conditions may have utility for scheduling Lake Piru releases. Additional ground-water and surfacewater data collection is needed to confirm the apparent relations described in this report.

\section{REFERENCES CITED}

Bailey, T.L., 1947, Origin and migration of oil into Sespe Redbeds, California: Bulletin of the American Association of Petroleum Geologists, v. 31, no. 11, p. 1913-1935.

Bailey, T.L., and Jahns, R.H., 1954, Geology of the Transverse Range Province, southern California, in Jahns, R.H., ed., Geology of Southern California, Chapter II, Geology of the natural provinces: California Division of Mines, Bulletin 170, p. 83-106.

Barlow, P.M., and Moench A.F., 1998, Analytical solutions and computer programs for hydraulic interaction of stream-aquifer systems: U.S. Geological Survey OpenFile Report 98-415, 75 p.

California Department of Water Resources, 1956, Ventura County investigation, v. 1, Bulletin 12, $489 \mathrm{p}$.

California Department of Water Resources, 1975, Compilation of technical information records for the Ventura County cooperative investigation, Vol. 1: Prepared by Ventura County Public Works Agency, Flood Control and Drainage Department, 28 p.

Carter, R.W., and Davidian, Jacob, 1968, General procedure for gaging streams: U.S. Geological Survey Techniques of Water-Resources Investigations, book 3, chap. A6, $13 \mathrm{p}$.

Cooper, H.H., Jr., Bredehoeft, J.D, and Papadopolous, I.S., 1967, Response of finite diameter well to an instantaneous charge of water: Water Resources Research, v. 3. no. 1, p. 263-269.

Coplen, T.B., 1994, Reporting of stable hydrogen, carbon, and oxygen isotopic abundances: Pure and Applied Chemistry, v. 66, p. 273-276.

Densmore, J.N., 1996, Lithologic and ground-water data for monitoring wells in the Santa Clara-Calleguas groundwater basin, Ventura County, California, 1989-95: U.S. Geological Survey Open File Report 96-120, 179 p.

Densmore, J. N., Middleton, G.K., and Izbicki, J.A., 1992, Surface-water releases for ground-water recharge, Santa Clara River, Ventura County, California, in Herrmann, Raymond, ed., Managing water resources during global change: American Water Resources Association, p. 407-416. 
Dibblee, T.W., Jr., 1991, Geologic map of the Piru quadrangle, Ventura County: Santa Barbara, California, Dibblee Geologic Foundation, Map \#DF-34.

Dibblee, T.W., Jr., 1992, Geologic map of the Saticoy quadrangle, Ventura County: Santa Barbara, California, Dibblee Geologic Foundation, Map \#DF-42.

Gat, J.R. and Gonfiantini, R., 1981, Stable isotope hydrology, Deuterium and the oxygen-18 in the water cycle: International Atomic Energy Agency Technical Report No. 210, Vienna, 337 p.

Gonfiantini, R., 1984, Advisory group meeting on stable isotope reference samples for geochemical and hydrological investigations, Vienna, 19-21 September, 1983: Report to Director General, International Atomic Energy Agency, Vienna, 77 p.

Helsel, D.R., and Hirsch, R.M., 1992, Statistical methods in water resources-Studies in environmental science, No. 49: Amsterdam, Elsevier Science Publishers, 522 p.

Izbicki, J.A., 1996, Source, movement, and age of ground water in a coastal California aquifer: U.S. Geological Survey Fact Sheet 126-96, 4 p.

Izbicki, J.A., Bullen, T.D., and Michel, M.L., 1994, Use of ${ }^{87} \mathrm{Sr} /{ }^{86} \mathrm{Sr}$ in ground water to identify the source of deposits underlying the Oxnard Plain and Pleasant Valley, California: EOS, Transactions American Geophysical Union, Supplement 1994 Fall Meeting, v. 75, no. 44, p. 280.

Izbicki, J.A., Martin, Peter, Densmore, J.N., and Clark, Dennis, 1995, Water-quality data for the Santa ClaraCalleguas Hydrologic Unit, Ventura County, California, October 1989-December 1993: U.S. Geological Survey Open-File Report 95-315, 125 p.

Kipp, K.L., 1985, Type curve analysis of inertial effects in the response of a well to a slug test: Water Resources Research, v. 21, no. 9, p. 1397-1408.

Law/Crandall, Inc., 1993, Water resources evaluation, Santa Paula ground water basin, Ventura County, California: Los Angeles, California, Law/Crandall, Inc., 71 p.

Mazor, Emanuel, 1991, Applied chemical and isotopic groundwater hydrology: Buckingham, U.K., Open University Press, 274 p.
Mosteller, F., and Tukey, J.W., 1977, Data analysis and regression: Reading, Massachusetts, Addison Wesley.

Neuman, S.P., 1981, Delayed drainage in a stream-aquifer system: Journal of the Irrigation and Drainage Division, Proceedings of the American Society of Civil Engineers, v. 107, no. IR4, p. 407-410.

Paybins, K.S., Nishikawa, Tracy, Izbicki, J.A., and Reichard, E.G., 1998, Statistical analysis and mathematical modeling of a tracer test on the Santa Clara River, Ventura County, California: U.S. Geological Survey Water-Resources Investigations Report 97-4275, 19 p.

Niskikawa, Tracy, Paybins, K.S., Izbicki, J.A., and Reichard, E.G., 1999, Numerical model of a tracer test on the Santa Clara River, Ventura County, California: Journal of the American Water Resources Association, v. 35, no. 1, p. 133-142.

Predmore., S.K., Koczot, K.M., and Paybins, K.S., 1997, Documentation and description of the digital spatial data base for the Southern California Regional AquiferSystem Analysis program, Santa Clara Calleguas Basin, Ventura County, California: U.S. Geological Survey Open-File Report 96-629, 100 p.

Reichard, E.G., 1995, Groundwater-surface water management with stochastic water supplies: A simulation-optimization approach: Water Resources Research, v. 31, no. 11, p. 2845-2865.

Turner, J.M., 1975, Ventura County Water Resources Management Study, Aquifer delineation in the OxnardCalleguas Area, Ventura County: Ventura County Department of Public Works, Flood Control District, 45 p.

Weber, F.H., Jr., Cleveland, G.B., Kahle, J.E., Kiessling, E.F., Miller, R.V., Mills, M.F., and Morton, D.F., 1973, Geology and mineral resources study of southern Ventura County, California: California Division of Mines and Geology, Preliminary Report 14, 102 p.

Yerkes, R.F., Sarna-Wojcicki, A.M., and Lajoie, K.R., 1987, Geology and Quaternary deformation of the Ventura area, in Recent reverse faulting in the Transverse Ranges, California: U.S. Geological Survey Professional Paper 1339, p. 169-176. 
APPENDIX 


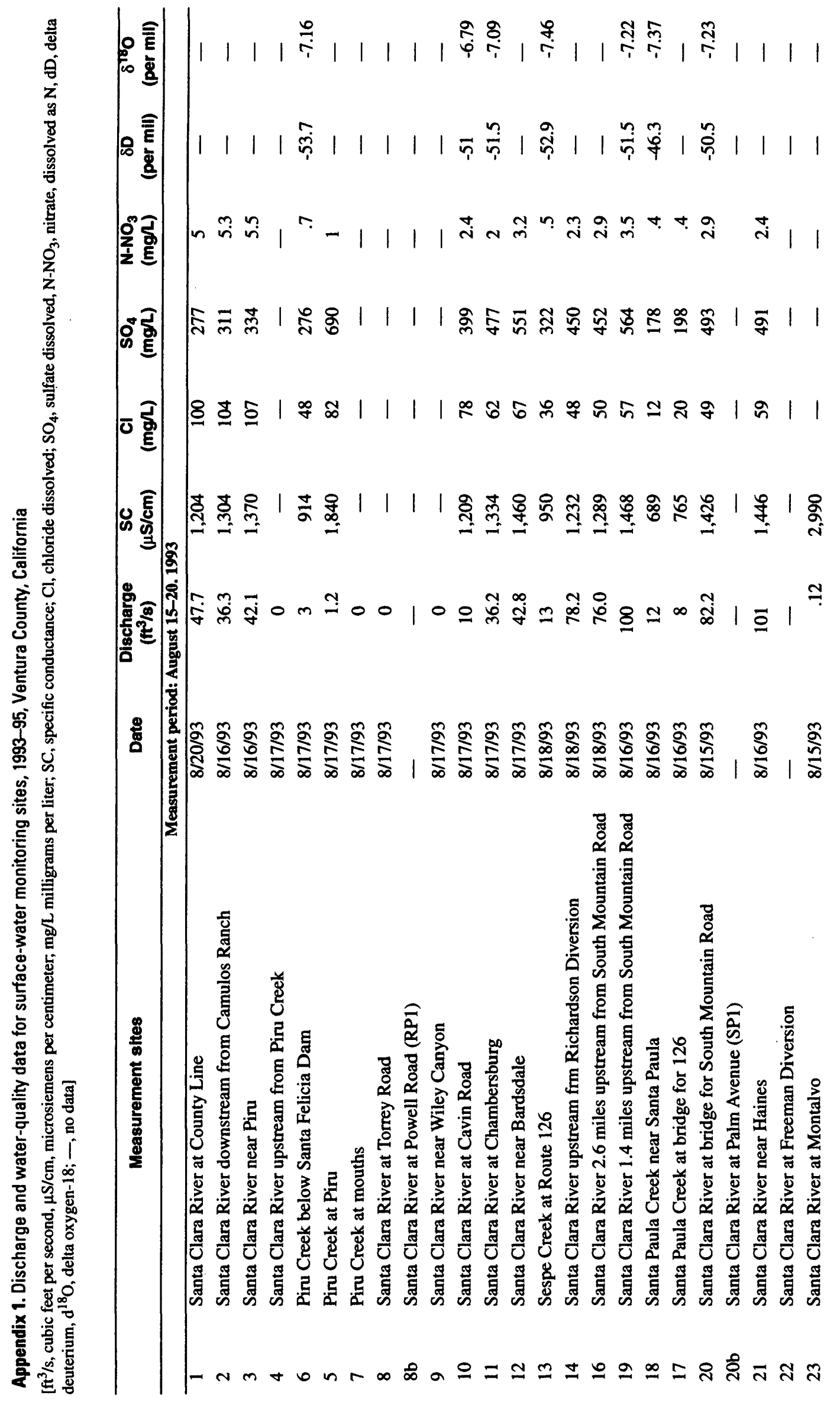




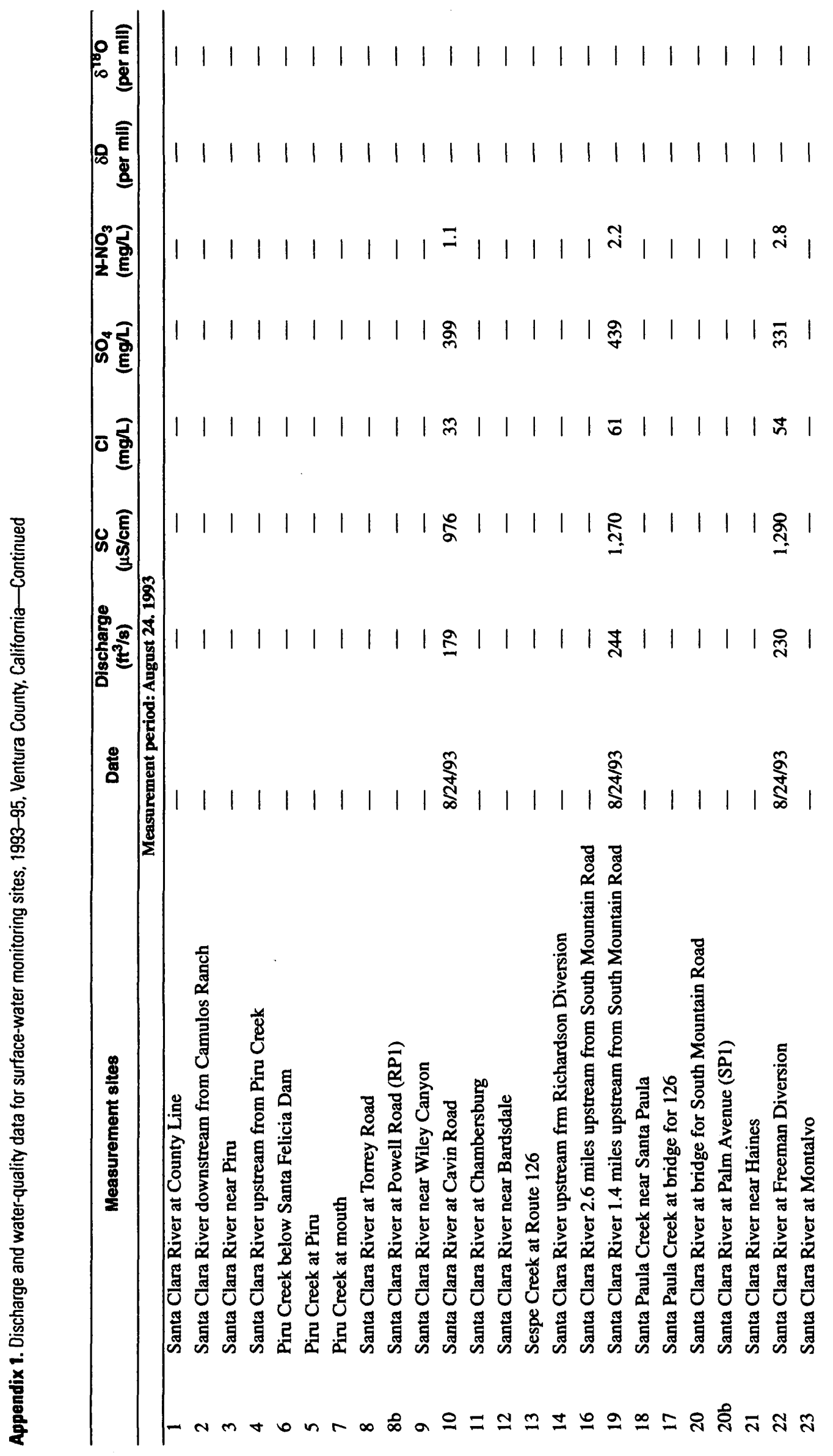




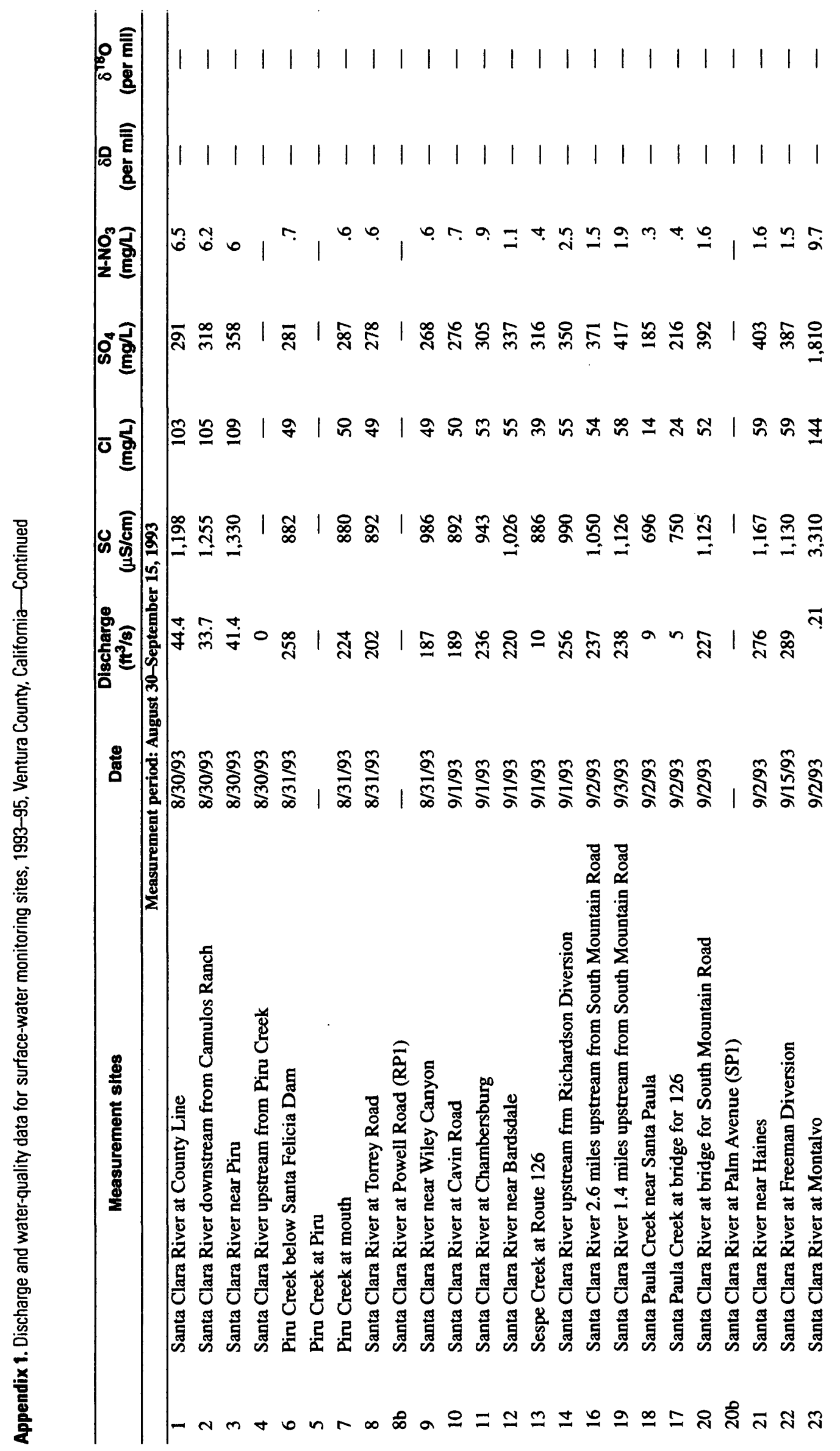









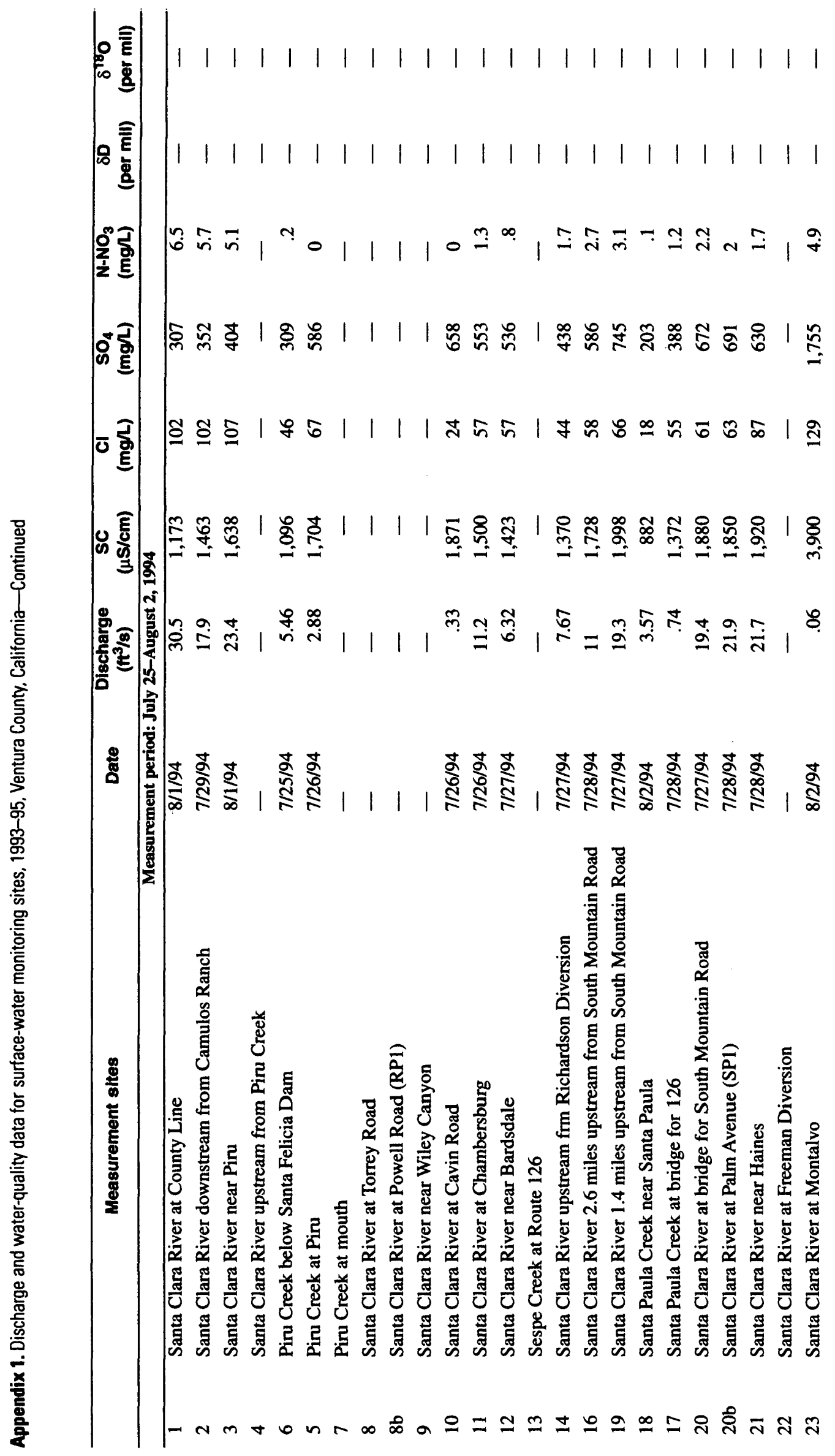




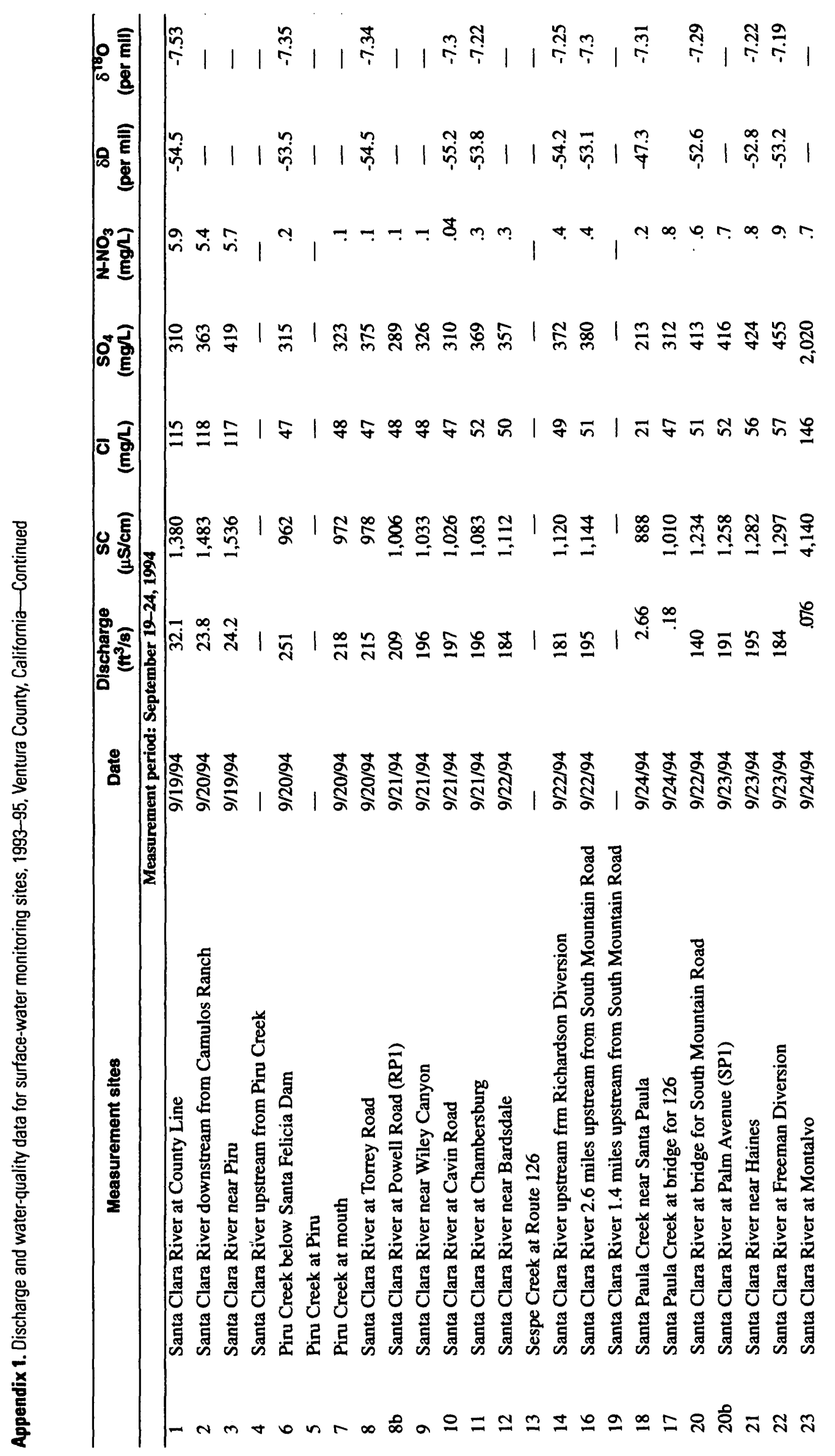




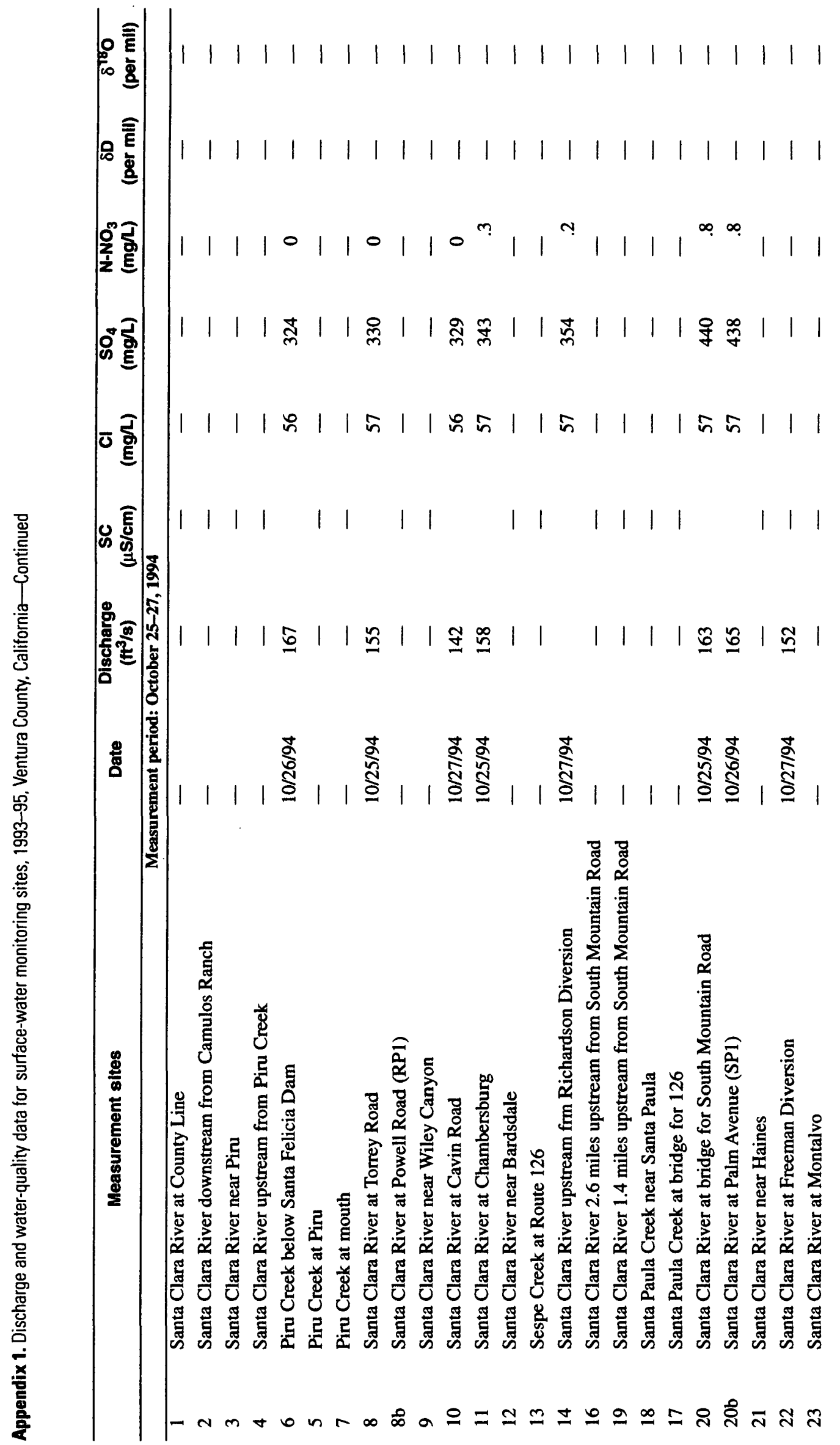




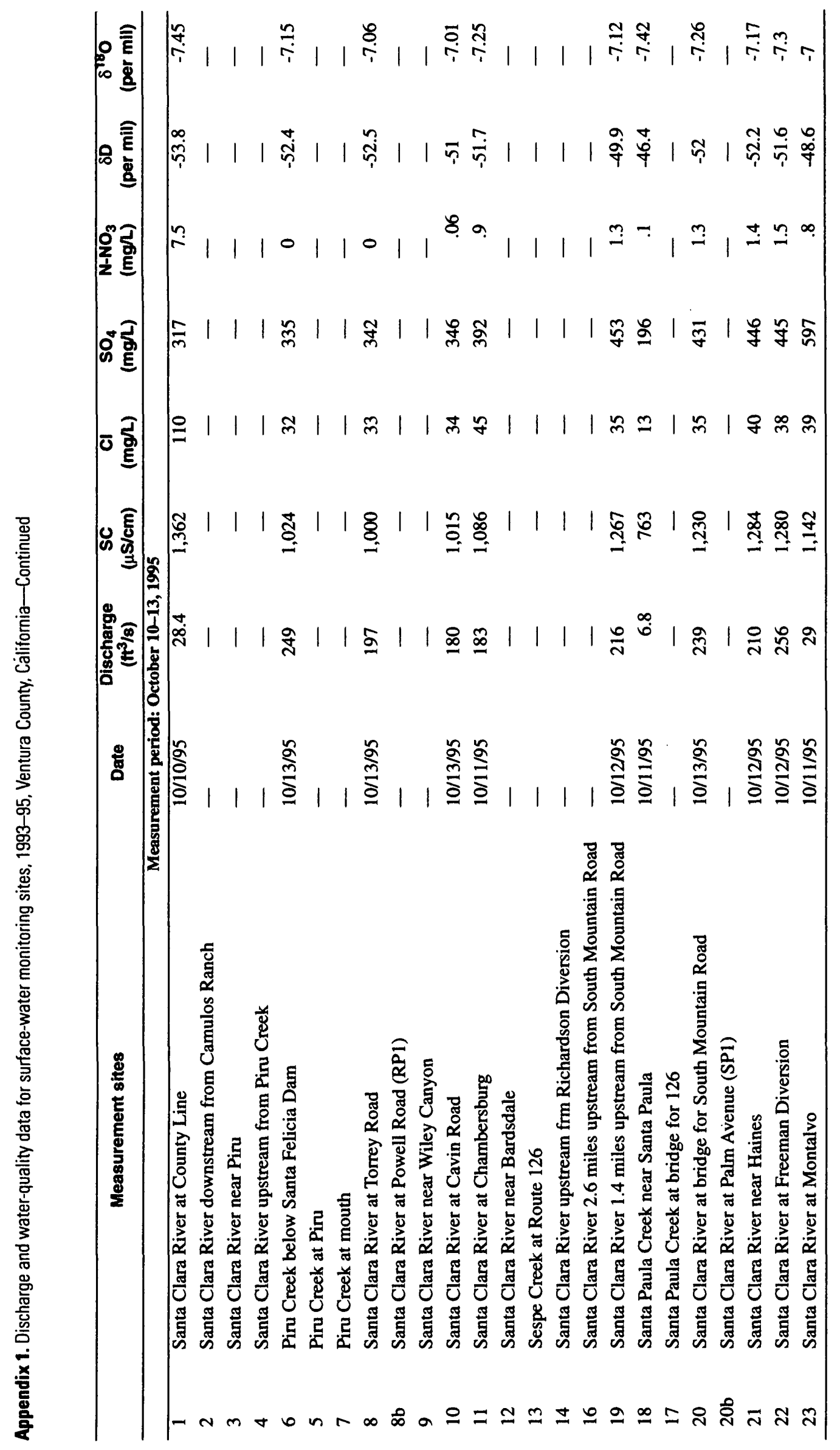




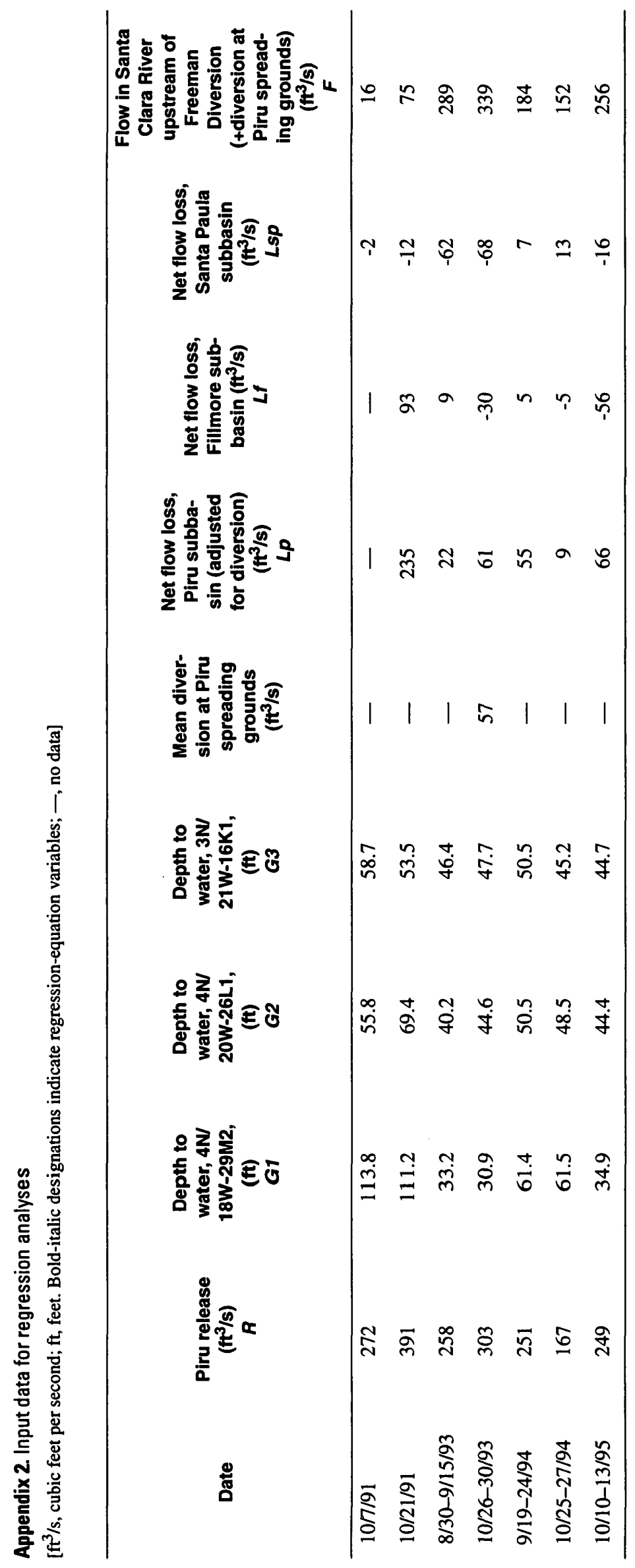

46 Evaluation of Surface-Water/Ground-Water Interactions in the Santa Clara River Valley, Ventura County, California 


\section{BLANK PAGE}






48 Evaluation of Surface-Water/Ground-Water Interactions in the Santa Clara River Valley, Ventura County, California 


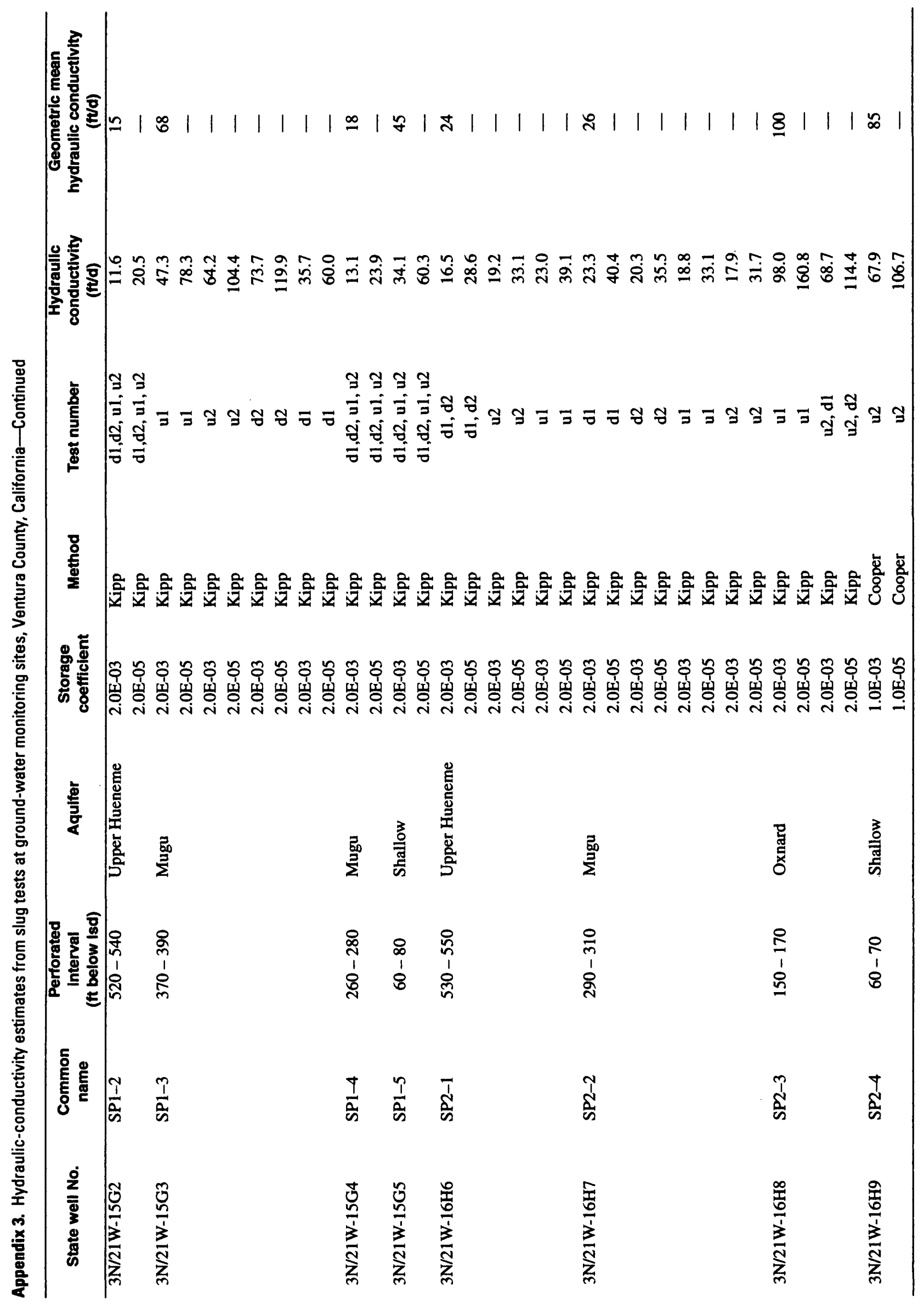




\begin{tabular}{|c|c|c|c|c|c|c|}
\hline State well No. & $\begin{array}{c}\text { Common } \\
\text { name }\end{array}$ & $\begin{array}{l}\text { Station Identifica- } \\
\text { tion No. }\end{array}$ & Date & $\begin{array}{l}\text { Water level, } \\
\text { (ft below lsd) }\end{array}$ & $\begin{array}{l}\text { Depth of } \\
\text { well, total } \\
\text { (ft) }\end{array}$ & $\begin{array}{c}\text { Alititude of lsd } \\
\text { (tt above sea } \\
\text { level) }\end{array}$ \\
\hline $3 \mathrm{~N} / 21 \mathrm{~W}-15 \mathrm{G}-\mathrm{CORE}$ & SP-1 CORE & 342034119040206 & $04-30-94$ & - & - & 236 \\
\hline $3 \mathrm{~N} / 21 \mathrm{~W}-15 \mathrm{G} 1$ & SP1-1 & 342034119040201 & $06-14-94$ & 40.85 & 680 & 236 \\
\hline $3 \mathrm{~N} / 21 \mathrm{~W}-15 \mathrm{G} 1$ & & 342034119040201 & 04-03-95 & 28.58 & 680 & 236 \\
\hline $3 \mathrm{~N} / 21 \mathrm{~W}-15 \mathrm{G} 1$ & & 342034119040201 & 09-06-96 & 51 & 680 & 236 \\
\hline 3N/21W-15G2 & SP1-2 & 342034119040202 & 06-14-94 & 41.1 & 540 & 236 \\
\hline $3 \mathrm{~N} / 21 \mathrm{~W}-15 \mathrm{G} 2$ & & 342034119040202 & 04-03-95 & 28.82 & 540 & 236 \\
\hline $3 \mathrm{~N} / 21 \mathrm{~W}-15 \mathrm{G} 2$ & & 342034119040202 & 09-06-96 & 50 & 540 & 236 \\
\hline $3 \mathrm{~N} / 21 \mathrm{~W}-15 \mathrm{G} 3$ & SP1-3 & 342034119040203 & $06-15-94$ & 41.33 & 390 & 236 \\
\hline $3 \mathrm{~N} / 21 \mathrm{~W}-15 \mathrm{G} 3$ & & 342034119040203 & $04-04-95$ & 29.04 & 390 & 236 \\
\hline $3 \mathrm{~N} / 21 \mathrm{~W}-15 \mathrm{G} 3$ & & 342034119040203 & $09-06-96$ & 49.35 & 390 & 236 \\
\hline $3 \mathrm{~N} / 21 \mathrm{~W}-15 \mathrm{G} 4$ & SP1-4 & 342034119040204 & $06-15-94$ & 41.55 & 280 & 236 \\
\hline $3 \mathrm{~N} / 21 \mathrm{~W}-15 \mathrm{G} 4$ & & 342034119040204 & $04-30-94$ & 29.29 & 280 & 236 \\
\hline $3 \mathrm{~N} / 21 \mathrm{~W}-15 \mathrm{G} 4$ & & 342034119040204 & $09-06-96$ & 49.21 & 280 & 236 \\
\hline 3N/21W-15G5 & SP1-5 & 342034119040205 & 06-14-94 & 23.22 & 80 & 236 \\
\hline $3 \mathrm{~N} / 21 \mathrm{~W}-15 \mathrm{G} 5$ & & 342034119040205 & $04-04-95$ & 20.7 & 80 & 236 \\
\hline $3 \mathrm{~N} / 21 \mathrm{~W}-15 \mathrm{G} 5$ & & 342034119040205 & $09-06-96$ & 24.43 & 80 & 236 \\
\hline $3 \mathrm{~N} / 21 \mathrm{~W}-16 \mathrm{H} 5$ & SP2-1 & 342035119044401 & $06-16-94$ & 46.25 & 550 & 240 \\
\hline $3 \mathrm{~N} / 21 \mathrm{~W}-16 \mathrm{H} 5$ & & 342035119044401 & $04-05-95$ & 34.61 & 550 & 240 \\
\hline $3 \mathrm{~N} / 21 \mathrm{~W}-16 \mathrm{H} 5$ & & 342035119044401 & $09-05-96$ & 55.43 & 550 & 240 \\
\hline $3 \mathrm{~N} / 21 \mathrm{~W}-16 \mathrm{H} 6$ & SP2-2 & 342035119044402 & $06-16-94$ & 46.52 & 310 & 240 \\
\hline $3 \mathrm{~N} / 21 \mathrm{~W}-16 \mathrm{H} 6$ & & 342035119044402 & $04-05-95$ & 34.2 & 310 & 240 \\
\hline $3 \mathrm{~N} / 21 \mathrm{~W}-16 \mathrm{H} 6$ & & 342035119044402 & $09-05-96$ & 54.15 & 310 & 240 \\
\hline $3 \mathrm{~N} / 21 \mathrm{~W}-16 \mathrm{H} 7$ & SP2-3 & 342035119044403 & 06-16-94 & 46.24 & 170 & 240 \\
\hline $3 \mathrm{~N} / 21 \mathrm{~W}-16 \mathrm{H} 7$ & & 342035119044403 & 04-05-95 & 33.64 & 170 & 240 \\
\hline $3 \mathrm{~N} / 21 \mathrm{~W}-16 \mathrm{H} 7$ & & 342035119044403 & 09-05-96 & 53.09 & 170 & 240 \\
\hline $3 \mathrm{~N} / 21 \mathrm{~W}-16 \mathrm{H} 8$ & SP2-4 & 342035119044404 & $06-15-94$ & 46.24 & 70 & 240 \\
\hline $3 \mathrm{~N} / 21 \mathrm{~W}-16 \mathrm{H} 8$ & & 342035119044404 & $04-05-95$ & 27.91 & 70 & 240 \\
\hline $3 \mathrm{~N} / 21 \mathrm{~W}-16 \mathrm{H} 8$ & & 342035119044404 & $09-05-96$ & 40.69 & 70 & 240 \\
\hline 4N/18W-31D3 & RP1-1 & 342335118484401 & $06-25-94$ & - & 610 & 592 \\
\hline 4N/18W-31D3 & & 342335118484401 & $04-06-95$ & 13.04 & 610 & 592 \\
\hline 4N/18W-31D3 & & 342335118484401 & $09-17-96$ & 44.6 & 610 & 592 \\
\hline 4N/18W-31D4 & RP1-2 & 342335118484402 & $06-25-94$ & - & 330 & 592 \\
\hline 4N/18W-31D4 & & 342335118484402 & $04-06-95$ & 9 & 330 & 592 \\
\hline 4N/18W-31D4 & & 342335118484402 & $09-17-96$ & 40.39 & 330 & 592 \\
\hline 4N/18W-31D5 & RP1-3 & 342335118484403 & $06-25-94$ & - & 240 & 592 \\
\hline 4N/18W-31D5 & & 342335118484403 & $04-06-95$ & 8.98 & 240 & 592 \\
\hline 4N/18W-31D5 & & 342335118484403 & $09-17-96$ & 40.69 & 240 & 592 \\
\hline 4N/18W-31D6 & RP1-4 & 342335118484404 & $06-25-94$ & - & 160 & 592 \\
\hline 4N/18W-31D6 & & 342335118484404 & $04-06-95$ & 9.09 & 160 & 592 \\
\hline 4N/18W-31D6 & & 342335118484404 & $09-17-96$ & 40.44 & 160 & 592 \\
\hline 4N/18W-31D7 & RP1-5 & 342335118484405 & $06-25-94$ & - & 70 & 592 \\
\hline 4N/18W-31D7 & & 342335118484405 & $04-06-95$ & 9.06 & 70 & 592 \\
\hline 4N/18W-31D7 & & 342335118484405 & $09-17-96$ & 40.16 & 70 & 592 \\
\hline
\end{tabular}




\begin{tabular}{|c|c|c|c|c|c|c|c|}
\hline State well No. & Date & $\begin{array}{l}\text { Depth to top } \\
\text { of sampled } \\
\text { Interval } \\
\text { (ft below } \\
\text { lsd) }\end{array}$ & $\begin{array}{l}\text { Depth to } \\
\text { bottom } \\
\text { of sam- } \\
\text { pled } \\
\text { Interval } \\
\text { (ft below } \\
\text { led) }\end{array}$ & $\begin{array}{c}\text { Speciflc } \\
\text { conduc- } \\
\text { tance, } \\
\text { fleld } \\
(\mu S / \mathrm{cm})\end{array}$ & $\begin{array}{c}\text { Speciflc } \\
\text { conduc- } \\
\text { tance, } \\
\text { lab } \\
(\mu S / c m)\end{array}$ & $\begin{array}{c}\text { pH, field } \\
\text { (8tandard } \\
\text { unit8) }\end{array}$ & $\begin{array}{c}\text { pH, lab } \\
\text { (8tandard } \\
\text { unlts) }\end{array}$ \\
\hline $3 \mathrm{~N} / 21 \mathrm{~W}-15 \mathrm{G}-\mathrm{CORE}$ & $04-30-94$ & 131 & 134 & - & - & - & - \\
\hline $3 N / 21 W-15 G 1$ & $06-14-94$ & - & - & 1,240 & 1,330 & 7.5 & 7.3 \\
\hline $3 N / 21 W-15 G 1$ & $04-03-95$ & 一 & 一 & 1,330 & 1,340 & 7.4 & 7.3 \\
\hline $3 N / 21 W-15 G 1$ & $09-06-96$ & 660 & 680 & 1,340 & 1,290 & 7.4 & 7.5 \\
\hline $3 N / 21 W-15 G 2$ & $06-14-94$ & - & - & 1,300 & 1,400 & 7.4 & 7.3 \\
\hline $3 N / 21 W-15 G 2$ & $04-03-95$ & - & - & 1,380 & 1,390 & 7.4 & 7.3 \\
\hline $3 N / 21 W-15 G 2$ & $09-06-96$ & 520 & 540 & 1,390 & 1,400 & 7.4 & 7.4 \\
\hline $3 N / 21 W-15 G 3$ & $06-15-94$ & - & - & 703 & 1,290 & 7.2 & 7.2 \\
\hline $3 \mathrm{~N} / 21 \mathrm{~W}-15 \mathrm{G} 3$ & $04-04-95$ & - & - & 1,280 & 1,300 & 7.3 & 7.2 \\
\hline $3 N / 21 W-15 G 3$ & $09-06-96$ & 370 & 390 & 1,320 & 1,340 & 7.3 & 7.4 \\
\hline $3 \mathrm{~N} / 21 \mathrm{~W}-15 \mathrm{G} 4$ & $06-15-94$ & - & - & 813 & 1,560 & 7.1 & 7.2 \\
\hline $3 N / 21 W-15 G 4$ & $04-30-94$ & - & - & 1,440 & 1,470 & 7.3 & 7.2 \\
\hline $3 \mathrm{~N} / 21 \mathrm{~W}-15 \mathrm{G} 4$ & $09-06-96$ & 260 & 280 & 1,550 & 1,560 & 7.3 & 7.4 \\
\hline $3 N / 21 W-15 G 5$ & $06-14-94$ & - & - & 1,420 & 1,510 & 7.4 & 7.3 \\
\hline $3 N / 21 W-15 G 5$ & $04-04-95$ & - & - & 1,480 & 1,520 & 7.4 & 7.3 \\
\hline $3 N / 21 W-15 G 5$ & $09-06-96$ & 60 & 80 & 1,480 & 1,490 & 7.4 & 7.4 \\
\hline $3 \mathrm{~N} / 21 \mathrm{~W}-16 \mathrm{H} 5$ & $06-16-94$ & - & - & 1,230 & 1,370 & 7.5 & 7.2 \\
\hline $3 \mathrm{~N} / 21 \mathrm{~W}-16 \mathrm{H} 5$ & $04-05-95$ & 一 & - & 1,330 & 1,350 & 7.3 & 7.3 \\
\hline $3 \mathrm{~N} / 21 \mathrm{~W}-16 \mathrm{H} 5$ & $09-05-96$ & 530 & 550 & 1,330 & 1,350 & 7.3 & 7.4 \\
\hline $3 N / 21 W-16 H 6$ & $06-16-94$ & - & 一 & 1,460 & 1,630 & 7.3 & 7.1 \\
\hline $3 \mathrm{~N} / 21 \mathrm{~W}-16 \mathrm{H} 6$ & $04-05-95$ & - & - & 1,580 & 1,610 & 7.2 & 7.3 \\
\hline $3 \mathrm{~N} / 21 \mathrm{~W}-16 \mathrm{H} 6$ & $09-05-96$ & 290 & 310 & 1,560 & 1,580 & 7.3 & 7.3 \\
\hline $3 \mathrm{~N} / 21 \mathrm{~W}-16 \mathrm{H} 7$ & $06-16-94$ & - & - & 1,580 & 1,700 & 7.3 & 7.2 \\
\hline $3 \mathrm{~N} / 21 \mathrm{~W}-16 \mathrm{H} 7$ & $04-05-95$ & - & - & 1,720 & 1,730 & 7.2 & 7.3 \\
\hline $3 \mathrm{~N} / 21 \mathrm{~W}-16 \mathrm{H} 7$ & $09-05-96$ & 150 & 170 & 1,620 & 1,640 & 7.3 & 7.4 \\
\hline $3 N / 21 W-16 \mathrm{H} 8$ & $06-15-94$ & - & - & 1,580 & 1,910 & 7.3 & 7.1 \\
\hline $3 N / 21 W-16 H 8$ & $04-05-95$ & - & - & 2,330 & 2,370 & 7.1 & 7.2 \\
\hline $3 N / 21 W-16 \mathrm{H} 8$ & $09-05-96$ & 60 & 70 & 2,430 & 2,440 & 7.1 & 7.3 \\
\hline $4 \mathrm{~N} / 18 \mathrm{~W}-31 \mathrm{D} 3$ & $06-25-94$ & - & - & 1,220 & 1,190 & 7.7 & 7.5 \\
\hline $4 \mathrm{~N} / 18 \mathrm{~W}-31 \mathrm{D} 3$ & $04-06-95$ & 一 & - & 1,240 & 1,210 & 7.5 & 7.4 \\
\hline $4 \mathrm{~N} / 18 \mathrm{~W}-31 \mathrm{D} 3$ & $09-17-96$ & 590 & 610 & 1,320 & 1,280 & 7.5 & 7.6 \\
\hline $4 \mathrm{~N} / 18 \mathrm{~W}-31 \mathrm{D} 4$ & $06-25-94$ & - & - & 1,370 & 1,360 & 7.5 & 7.5 \\
\hline 4N/18W-31D4 & $04-06-95$ & - & - & 1,430 & 1,430 & 7.6 & 7.4 \\
\hline $4 N / 18 W-31 D 4$ & $09-17-96$ & 310 & 330 & 1,400 & 1,340 & 7.5 & 7.6 \\
\hline $4 \mathrm{~N} / 18 \mathrm{~W}-31 \mathrm{D} 5$ & $06-25-94$ & - & - & 1,020 & 1,010 & 7.5 & 7.6 \\
\hline $4 \mathrm{~N} / 18 \mathrm{~W}-31 \mathrm{D} 5$ & $04-06-95$ & - & - & 1,040 & 1,030 & 7.6 & 7.3 \\
\hline $4 \mathrm{~N} / 18 \mathrm{~W}-31 \mathrm{D} 5$ & $09-17-96$ & 220 & 240 & 1,170 & 1,140 & 7.6 & 7.6 \\
\hline $4 \mathrm{~N} / 18 \mathrm{~W}-31 \mathrm{D} 6$ & $06-25-94$ & - & - & 1,100 & 1,080 & 7.5 & 7.6 \\
\hline 4N/18W-31D6 & $04-06-95$ & - & - & 1,100 & 1,080 & 7.7 & 7.4 \\
\hline $4 \mathrm{~N} / 18 \mathrm{~W}-31 \mathrm{D} 6$ & $09-17-96$ & 140 & 160 & 1,100 & 1,070 & 7.6 & 7.7 \\
\hline $4 \mathrm{~N} / 18 \mathrm{~W}-31 \mathrm{D} 7$ & $06-25-94$ & - & - & 1,130 & 1,120 & 7.5 & 7.6 \\
\hline $4 \mathrm{~N} / 18 \mathrm{~W}-31 \mathrm{D} 7$ & $04-06-95$ & - & - & 1,070 & 1,050 & 7.7 & 7.5 \\
\hline 4N/18W-31D7 & $09-17-96$ & 50 & 70 & 1,120 & 1,090 & 7.7 & 7.7 \\
\hline
\end{tabular}




\begin{tabular}{|c|c|c|c|c|c|c|c|c|}
\hline State well No. & Date & $\begin{array}{l}\text { Temper- } \\
\text { ature, } \\
\text { water } \\
\left({ }^{\circ} \mathrm{C}\right)\end{array}$ & $\begin{array}{l}\text { Temper- } \\
\text { ature, } \\
\text { air } \\
\text { (ㄷ) }\end{array}$ & $\begin{array}{l}\text { Oxygen, } \\
\text { dissolved } \\
\text { (mg/L) }\end{array}$ & $\begin{array}{l}\text { Calcium, } \\
\text { dissolved } \\
\text { (mg/l as } \\
\text { Ca) }\end{array}$ & $\begin{array}{l}\text { Magne- } \\
\text { slum, } \\
\text { dissolved } \\
\text { (mg/L as } \\
\text { Mg) }\end{array}$ & $\begin{array}{l}\text { Sodium, } \\
\text { dissolved } \\
\text { (mg/l as } \\
\mathrm{Na})\end{array}$ & $\begin{array}{l}\text { Potas- } \\
\text { slum, } \\
\text { dlssolved } \\
\text { (mg/L as } \\
\text { K) }\end{array}$ \\
\hline 3N/21W-15G-CORE & $04-30-94$ & - & - & - & - & - & - & - \\
\hline $3 N / 21 W-15 G 1$ & 06-14-94 & 19.0 & - & - & 150 & 41 & 97 & 4.5 \\
\hline 3N/21W-15G1 & $04-03-95$ & 19.0 & 27.0 & - & 140 & 41 & 94 & 4.9 \\
\hline $3 \mathrm{~N} / 21 \mathrm{~W}-15 \mathrm{G} 1$ & $09-06-96$ & 20.0 & - & .4 & 140 & 40 & 92 & 4.1 \\
\hline $3 N / 21 W-15 G 2$ & $06-14-94$ & 19.0 & - & - & 150 & 43 & 98 & 4.4 \\
\hline $3 \mathrm{~N} / 21 \mathrm{~W}-15 \mathrm{G} 2$ & 04-03-95 & 18.5 & 27.0 & - & 150 & 46 & 91 & 4.2 \\
\hline $3 \mathrm{~N} / 21 \mathrm{~W}-15 \mathrm{G} 2$ & $09-06-96$ & 20.0 & - & .4 & 150 & 43 & 87 & 4.1 \\
\hline $3 N / 21 W-15 G 3$ & $06-15-94$ & 19.5 & - & - & 150 & 39 & 83 & 3.0 \\
\hline $3 N / 21 W-15 G 3$ & 04-04-95 & 18.0 & 22.0 & - & 140 & 40 & 79 & 3.2 \\
\hline $3 N / 21 W-15 G 3$ & $09-06-96$ & 19.5 & - & .3 & 150 & 39 & 76 & 3.0 \\
\hline 3N/21W-15G4 & $06-15-94$ & 19.5 & - & - & 180 & 45 & 110 & 4.2 \\
\hline 3N/21W-15G4 & 04-30-94 & 18.5 & 24.5 & - & 160 & 45 & 97 & 3.8 \\
\hline $3 \mathrm{~N} / 21 \mathrm{~W}-15 \mathrm{G} 4$ & 09-06-96 & 19.0 & - & .4 & 180 & 49 & 100 & 3.5 \\
\hline $3 \mathrm{~N} / 21 \mathrm{~W}-15 \mathrm{G} 5$ & $06-14-94$ & 17.5 & - & - & 150 & 50 & 110 & 4.9 \\
\hline 3N/21W-15G5 & 04-04-95 & 17.5 & 22.0 & - & 150 & 53 & 110 & 3.9 \\
\hline $3 N / 21 W-15 G 5$ & $09-06-96$ & 19.0 & - & .1 & 150 & 56 & 110 & 4.8 \\
\hline $3 \mathrm{~N} / 21 \mathrm{~W}-16 \mathrm{H} 5$ & $06-16-94$ & 20.0 & - & - & 150 & 40 & 86 & 3.2 \\
\hline $3 \mathrm{~N} / 21 \mathrm{~W}-16 \mathrm{H} 5$ & $04-05-95$ & 18.0 & 15.5 & - & 150 & 41 & 85 & 3.1 \\
\hline $3 \mathrm{~N} / 21 \mathrm{~W}-16 \mathrm{H} 5$ & $09-05-96$ & 20.0 & - & .4 & 150 & 38 & 79 & 3.0 \\
\hline $3 \mathrm{~N} / 21 \mathrm{~W}-16 \mathrm{H} 6$ & $06-16-94$ & 20.0 & - & - & 230 & 48 & 110 & 3.4 \\
\hline $3 \mathrm{~N} / 21 \mathrm{~W}-16 \mathrm{H} 6$ & $04-05-95$ & 19.5 & 20.5 & - & 190 & 47 & 100 & 3.1 \\
\hline $3 \mathrm{~N} / 21 \mathrm{~W}-16 \mathrm{H} 6$ & $09-05-96$ & 20.5 & - & .4 & 190 & 45 & 100 & 3.0 \\
\hline $3 \mathrm{~N} / 21 \mathrm{~W}-16 \mathrm{H} 7$ & $06-16-94$ & 21.0 & - & - & 200 & 60 & 110 & 4.0 \\
\hline $3 \mathrm{~N} / 21 \mathrm{~W}-16 \mathrm{H} 7$ & 04-05-95 & 18.5 & 18.5 & - & 200 & 60 & 110 & 3.8 \\
\hline $3 \mathrm{~N} / 21 \mathrm{~W}-16 \mathrm{H} 7$ & $09-05-96$ & 20.5 & - & .2 & 190 & 52 & 100 & 3.6 \\
\hline $3 \mathrm{~N} / 21 \mathrm{~W}-16 \mathrm{H} 8$ & $06-15-94$ & 21.0 & - & - & 180 & 59 & 160 & 3.6 \\
\hline $3 \mathrm{~N} / 21 \mathrm{~W}-16 \mathrm{H} 8$ & $04-05-95$ & 19.5 & 21.0 & - & 190 & 80 & 240 & 3.6 \\
\hline $3 \mathrm{~N} / 21 \mathrm{~W}-16 \mathrm{H} 8$ & $09-05-96$ & 21.0 & - & .2 & 220 & 73 & 240 & 3.5 \\
\hline 4N/18W-31D3 & $06-25-94$ & 16.5 & - & - & 110 & 43 & 82 & 4.5 \\
\hline 4N/18W-31D3 & $04-06-95$ & 15.5 & 20.5 & 7.6 & 130 & 47 & 81 & 4.3 \\
\hline 4N/18W-31D3 & $09-17-96$ & 16.0 & - & 7.7 & 130 & 51 & 83 & 4.2 \\
\hline $4 \mathrm{~N} / 18 \mathrm{~W}-31 \mathrm{D} 4$ & $06-25-94$ & 17.5 & - & - & 120 & 47 & 98 & 5.1 \\
\hline 4N/18W-31D4 & 04-06-95 & 16.0 & 19.5 & 5.4 & 140 & 54 & 95 & 4.9 \\
\hline 4N/18W-31D4 & $09-17-96$ & 17.0 & - & 5.0 & 130 & 52 & 93 & 4.6 \\
\hline 4N/18W-31D5 & $06-25-94$ & 18.5 & - & - & 81 & 30 & 84 & 4.3 \\
\hline 4N/18W-31D5 & $04-06-95$ & 16.5 & 22.0 & 8.0 & 93 & 33 & 79 & 4.4 \\
\hline 4N/18W-31D5 & $09-17-96$ & 17.0 & - & 4.8 & 100 & 38 & 86 & 4.3 \\
\hline 4N/18W-31D6 & $06-25-94$ & 18.0 & - & - & 94 & 34 & 83 & 4.6 \\
\hline 4N/18W-31D6 & $04-06-95$ & 15.0 & 17.0 & 3.2 & 110 & 37 & 80 & 4.6 \\
\hline 4N/18W-31D6 & $09-17-96$ & 16.5 & - & 3.7 & 98 & 37 & 76 & 4.4 \\
\hline 4N/18W-31D7 & $06-25-94$ & 18.0 & - & - & 93 & 30 & 100 & 5.1 \\
\hline 4N/18W-31D7 & $04-06-95$ & 16.0 & 20.0 & 9.6 & 110 & 33 & 76 & 5.0 \\
\hline $4 \mathrm{~N} / 18 \mathrm{~W}-31 \mathrm{D} 7$ & $09-17-96$ & 19.5 & - & .6 & 110 & 38 & 68 & 4.8 \\
\hline
\end{tabular}




\begin{tabular}{|c|c|c|c|c|c|c|c|}
\hline State well No. & Date & $\begin{array}{l}\text { Alkalinity, } \\
\text { filtered, } \\
\text { flxed end- } \\
\text { point titra- } \\
\text { tion (mg/ } \\
\text { as } \mathrm{CaCO}_{3} \text { ) }\end{array}$ & $\begin{array}{l}\text { Alkalinity, } \\
\text { flitered, } \\
\text { incremental } \\
\text { titration } \\
\left(\mathrm{mg}^{2} \mathrm{as}\right. \\
\left.\mathrm{CaCO}_{3}\right)\end{array}$ & $\begin{array}{c}\text { Alkalinity, } \\
\text { lab }(\mathrm{mg} / \mathrm{L} \text { as } \\
\left.\mathrm{CaCO}_{3}\right)\end{array}$ & $\begin{array}{c}\text { Sulfate, } \\
\text { dissolved } \\
\text { (mgh as } \\
\left.\mathrm{SO}_{4}\right)\end{array}$ & $\begin{array}{l}\text { Chloride, } \\
\text { dlssolved } \\
\text { (mg/L as Cl) }\end{array}$ & $\begin{array}{l}\text { Flouride, } \\
\text { dlssolved, } \\
\text { (mg/L as F) }\end{array}$ \\
\hline $3 \mathrm{~N} / 21 \mathrm{~W}-15 \mathrm{G}-\mathrm{CORE}$ & 04-30-94 & - & - & - & 3,000 & 220 & - \\
\hline $3 \mathrm{~N} / 21 \mathrm{~W}-15 \mathrm{G} 1$ & $06-14-94$ & 220 & 219 & 228 & 440 & 44 & .6 \\
\hline $3 N / 21 W-15 G 1$ & 04-03-95 & - & - & 225 & 420 & 43 & .6 \\
\hline $3 \mathrm{~N} / 21 \mathrm{~W}-15 \mathrm{G} 1$ & 09-06-96 & 210 & - & 228 & 450 & 45 & .6 \\
\hline $3 N / 21 W-15 G 2$ & $06-14-94$ & 230 & 234 & 242 & 470 & 42 & .7 \\
\hline $3 N / 21 W-15 G 2$ & 04-03-95 & - & - & 237 & 450 & 42 & .6 \\
\hline $3 N / 21 W-15 G 2$ & $09-06-96$ & 220 & - & 239 & 470 & 42 & .7 \\
\hline $3 N / 21 W-15 G 3$ & $06-15-94$ & 220 & 223 & 232 & 420 & 43 & .7 \\
\hline $3 \mathrm{~N} / 21 \mathrm{~W}-15 \mathrm{G} 3$ & 04-04-95 & - & - & 228 & 400 & 44 & .7 \\
\hline $3 \mathrm{~N} / 21 \mathrm{~W}-15 \mathrm{G} 3$ & 09-06-96 & 220 & - & 231 & 430 & 44 & .7 \\
\hline $3 \mathrm{~N} / 21 \mathrm{~W}-15 \mathrm{G} 4$ & $06-15-94$ & 260 & 264 & 272 & 530 & 53 & .7 \\
\hline $3 N / 21 W-15 G 4$ & $04-30-94$ & - & - & 255 & 460 & 51 & .7 \\
\hline $3 N / 21 W-15 G 4$ & $09-06-96$ & 250 & - & 263 & 530 & 53 & .7 \\
\hline $3 N / 21 W-15 G 5$ & $06-14-94$ & 280 & 286 & 296 & 490 & 50 & .8 \\
\hline 3N/21W-15G5 & $04-04-95$ & - & - & 271 & 480 & 52 & .8 \\
\hline 3N/21W-15G5 & $09-06-96$ & 250 & - & 268 & 480 & 52 & .8 \\
\hline $3 \mathrm{~N} / 21 \mathrm{~W}-16 \mathrm{H} 5$ & $06-16-94$ & 260 & 252 & 265 & 420 & 46 & .6 \\
\hline $3 \mathrm{~N} / 21 \mathrm{~W}-16 \mathrm{H} 5$ & $04-05-95$ & - & - & 264 & 380 & 42 & .6 \\
\hline $3 \mathrm{~N} / 21 \mathrm{~W}-16 \mathrm{H} 5$ & $09-05-96$ & 250 & - & 266 & 400 & 44 & .6 \\
\hline $3 \mathrm{~N} / 21 \mathrm{~W}-16 \mathrm{H} 6$ & $06-16-94$ & 260 & 262 & 270 & 570 & 56 & .5 \\
\hline $3 \mathrm{~N} / 21 \mathrm{~W}-16 \mathrm{H} 6$ & $04-05-95$ & - & - & 269 & 520 & 54 & .5 \\
\hline $3 \mathrm{~N} / 21 \mathrm{~W}-16 \mathrm{H} 6$ & $09-05-96$ & 250 & - & 269 & 530 & 55 & .5 \\
\hline $3 \mathrm{~N} / 21 \mathrm{~W}-16 \mathrm{H} 7$ & $06-16-94$ & 260 & 260 & 264 & 670 & 65 & .7 \\
\hline $3 \mathrm{~N} / 21 \mathrm{~W}-16 \mathrm{H} 7$ & $04-05-95$ & - & - & 268 & 600 & 62 & .7 \\
\hline $3 \mathrm{~N} / 21 \mathrm{~W}-16 \mathrm{H} 7$ & $09-05-96$ & 260 & - & 274 & 560 & 53 & .7 \\
\hline $3 \mathrm{~N} / 21 \mathrm{~W}-16 \mathrm{H} 8$ & $06-15-94$ & 260 & 260 & 315 & 680 & 76 & $<.10$ \\
\hline $3 \mathrm{~N} / 21 \mathrm{~W}-16 \mathrm{H} 8$ & $04-05-95$ & - & - & 319 & 820 & 110 & .5 \\
\hline $3 \mathrm{~N} / 21 \mathrm{~W}-16 \mathrm{H} 8$ & 09-05-96 & 300 & - & 318 & 890 & 120 & .5 \\
\hline 4N/18W-31D3 & $06-25-94$ & 160 & 158 & 174 & 430 & 30 & .8 \\
\hline $4 \mathrm{~N} / 18 \mathrm{~W}-31 \mathrm{D} 3$ & $04-06-95$ & - & - & 171 & 440 & 32 & .9 \\
\hline 4N/18W-31D3 & $09-17-96$ & 170 & - & 174 & 500 & 34 & .9 \\
\hline 4N/18W-31D4 & $06-25-94$ & 200 & 200 & 218 & 430 & 60 & .9 \\
\hline 4N/18W-31D4 & 04-06-95 & - & - & 223 & 440 & 68 & .9 \\
\hline 4N/18W-31D4 & $09-17-96$ & 220 & - & 218 & 410 & 81 & .9 \\
\hline 4N/18W-31D5 & $06-25-94$ & 130 & 138 & 158 & 270 & 65 & .9 \\
\hline 4N/18W-31D5 & $04-06-95$ & - & - & 156 & 290 & 61 & .9 \\
\hline 4N/18W-31D5 & $09-17-96$ & 170 & - & 174 & 370 & 54 & .9 \\
\hline 4N/18W-31D6 & $06-25-94$ & 150 & 144 & 160 & 340 & 50 & .8 \\
\hline 4N/18W-31D6 & 04-06-95 & - & - & 167 & 330 & 52 & .8 \\
\hline 4N/18W-31D6 & $09-17-96$ & 170 & - & 172 & 340 & 45 & .8 \\
\hline 4N/18W-31D7 & $06-25-94$ & 170 & 168 & 187 & 320 & 55 & .6 \\
\hline 4N/18W-31D7 & $04-06-95$ & - & - & 152 & 330 & 44 & .6 \\
\hline 4N/18W-31D7 & $09-17-96$ & 170 & - & 173 & 370 & 38 & .6 \\
\hline
\end{tabular}




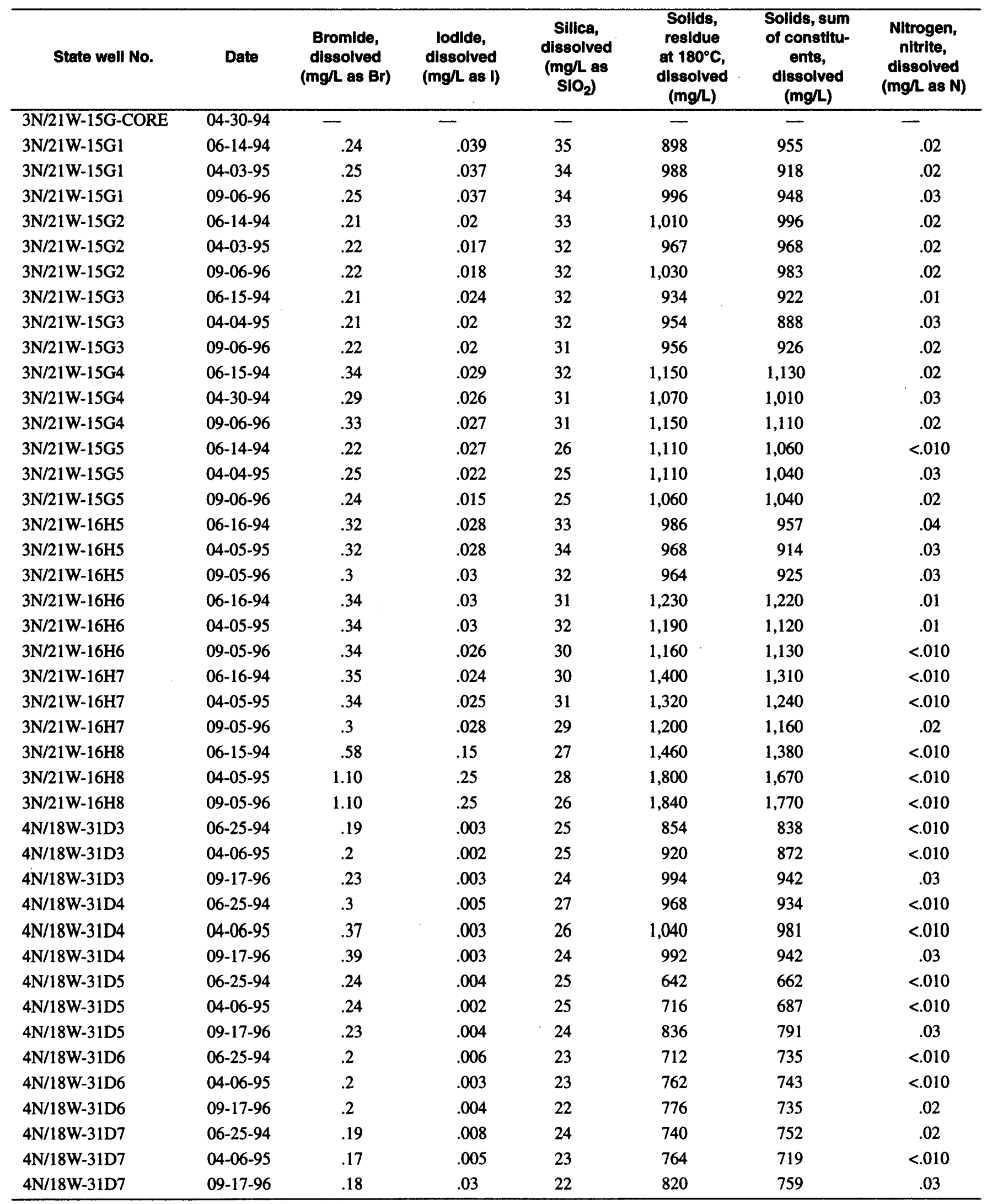




\begin{tabular}{|c|c|c|c|c|c|c|c|}
\hline State well No. & Date & $\begin{array}{c}\text { Nitrogen, } \\
\mathrm{NO}_{2}+\mathrm{NO}_{3} \text {, } \\
\text { dlssolved } \\
\text { (mg/L as N) }\end{array}$ & $\begin{array}{l}\text { Nitrogen, } \\
\text { ammonla, } \\
\text { dissolved } \\
\text { ( } \mathrm{mg} / \mathrm{L} \text { as } \mathrm{N} \text { ) }\end{array}$ & $\begin{array}{l}\text { Nitrogen, } \\
\text { ammonla + } \\
\text { organic, } \\
\text { dissolved } \\
\text { (mg/l as N) }\end{array}$ & $\begin{array}{l}\text { Phosphorus, } \\
\text { dlssolved } \\
\text { (mg/L as P) }\end{array}$ & $\begin{array}{l}\text { Phosphate, } \\
\text { ortho, } \\
\text { dissolved } \\
\text { (mg/L as P) }\end{array}$ & $\begin{array}{c}\text { Barlum, } \\
\text { dissolved } \\
(\mu g / L \text { as Ba) }\end{array}$ \\
\hline $3 \mathrm{~N} / 21 \mathrm{~W}-15 \mathrm{G}-\mathrm{CORE}$ & $04-30-94$ & $<.100$ & $\overline{-}$ & $\overline{-}$ & - & - & - \\
\hline $3 \mathrm{~N} / 21 \mathrm{~W}-15 \mathrm{G} 1$ & $06-14-94$ & .79 & .05 & $<.20$ & .02 & .02 & 20 \\
\hline $3 \mathrm{~N} / 21 \mathrm{~W}-15 \mathrm{G} 1$ & 04-03-95 & .8 & $<.015$ & $<.20$ & .02 & .02 & 20 \\
\hline $3 \mathrm{~N} / 21 \mathrm{~W}-15 \mathrm{G} 1$ & $09-06-96$ & .8 & $<.015$ & $<.20$ & .02 & .03 & 17 \\
\hline $3 \mathrm{~N} / 21 \mathrm{~W}-15 \mathrm{G} 2$ & $06-14-94$ & 2 & .08 & $<.20$ & .34 & .27 & 23 \\
\hline $3 \mathrm{~N} / 21 \mathrm{~W}-15 \mathrm{G} 2$ & $04-03-95$ & 2 & $<.015$ & $<.20$ & .06 & .07 & 23 \\
\hline $3 N / 21 W-15 G 2$ & $09-06-96$ & 2 & $<.015$ & $<.20$ & .02 & .05 & 20 \\
\hline $3 N / 21 \mathrm{~W}-15 \mathrm{G} 3$ & $06-15-94$ & 2 & .04 & $<.20$ & .18 & .14 & 25 \\
\hline $3 N / 21 W-15 G 3$ & $04-04-95$ & 2 & $<.015$ & $<.20$ & .05 & .05 & 25 \\
\hline $3 \mathrm{~N} / 21 \mathrm{~W}-15 \mathrm{G} 3$ & $09-06-96$ & 3 & $<.015$ & $<.20$ & .04 & .04 & 23 \\
\hline $3 N / 21 W-15 G 4$ & $06-15-94$ & 2 & .08 & $<.20$ & .44 & .22 & 32 \\
\hline $3 N / 21 W-15 G 4$ & $04-30-94$ & 2 & .02 & $<.20$ & .22 & .23 & 28 \\
\hline $3 N / 21 W-15 G 4$ & $09-06-96$ & 2 & $<.015$ & $<.20$ & .18 & .22 & 28 \\
\hline $3 N / 21 W-15 G 5$ & $06-14-94$ & .3 & .03 & $<.20$ & .15 & .11 & 23 \\
\hline 3N/21W-15G5 & 04-04-95 & .4 & $<.015$ & $<.20$ & .07 & .07 & 23 \\
\hline $3 \mathrm{~N} / 21 \mathrm{~W}-15 \mathrm{G} 5$ & 09-06-96 & .51 & $<.015$ & $<.20$ & .04 & .05 & 24 \\
\hline $3 \mathrm{~N} / 21 \mathrm{~W}-16 \mathrm{H} 5$ & $06-16-94$ & 4 & .03 & $<.20$ & .06 & .05 & 23 \\
\hline $3 \mathrm{~N} / 21 \mathrm{~W}-16 \mathrm{H} 5$ & $04-05-95$ & 4 & $<.015$ & - & - & .06 & 26 \\
\hline $3 \mathrm{~N} / 21 \mathrm{~W}-16 \mathrm{H} 5$ & 09-05-96 & 4 & $<.015$ & $<.20$ & .05 & .03 & 23 \\
\hline $3 \mathrm{~N} / 21 \mathrm{~W}-16 \mathrm{H} 6$ & $06-16-94$ & 2 & .02 & $<.20$ & .73 & .31 & 27 \\
\hline $3 \mathrm{~N} / 21 \mathrm{~W}-16 \mathrm{H} 6$ & 04-05-95 & 2 & $<.015$ & $<.20$ & .24 & .23 & 29 \\
\hline $3 \mathrm{~N} / 21 \mathrm{~W}-16 \mathrm{H} 6$ & 09-05-96 & 3 & $<.015$ & $<.20$ & .08 & .11 & 27 \\
\hline $3 \mathrm{~N} / 21 \mathrm{~W}-16 \mathrm{H} 7$ & $06-16-94$ & .92 & .02 & $<.20$ & .67 & .25 & 27 \\
\hline $3 \mathrm{~N} / 21 \mathrm{~W}-16 \mathrm{H} 7$ & $04-05-95$ & 1 & $<.015$ & $<.20$ & .13 & .11 & 29 \\
\hline $3 \mathrm{~N} / 21 \mathrm{~W}-16 \mathrm{H} 7$ & 09-05-96 & 1 & $<.015$ & $<.20$ & .04 & .07 & 24 \\
\hline $3 \mathrm{~N} / 21 \mathrm{~W}-16 \mathrm{H} 8$ & $06-15-94$ & $<.050$ & .03 & $<.20$ & .06 & .06 & 26 \\
\hline $3 \mathrm{~N} / 21 \mathrm{~W}-16 \mathrm{H} 8$ & $04-05-95$ & $<.050$ & .04 & $<.20$ & $<.010$ & .02 & $<100$ \\
\hline $3 \mathrm{~N} / 21 \mathrm{~W}-16 \mathrm{H} 8$ & $09-05-96$ & .08 & .06 & $<.20$ & .03 & .03 & 24 \\
\hline 4N/18W-31D3 & $06-25-94$ & 1 & .02 & $<.20$ & .23 & .17 & 12 \\
\hline 4N/18W-31D3 & 04-06-95 & 2 & $<.015$ & $<.20$ & .1 & .09 & 14 \\
\hline 4N/18W-31D3 & $09-17-96$ & 2 & $<.020$ & $<.20$ & .03 & .04 & 16 \\
\hline 4N/18W-31D4 & $06-25-94$ & 3 & .02 & .2 & 1.20 & .57 & 15 \\
\hline 4N/18W-31D4 & 04-06-95 & 4 & $<.015$ & $<.20$ & .24 & .22 & 20 \\
\hline 4N/18W-31D4 & $09-17-96$ & 3 & .02 & $<.20$ & .11 & .12 & 20 \\
\hline 4N/18W-31D5 & $06-25-94$ & .93 & .02 & $<.20$ & .47 & .36 & 12 \\
\hline 4N/18W-31D5 & $04-06-95$ & 1 & $<.015$ & $<.20$ & .13 & .14 & 16 \\
\hline 4N/18W-31D5 & $09-17-96$ & 2 & .02 & $<.20$ & .05 & .08 & 21 \\
\hline 4N/18W-31D6 & $06-25-94$ & 2 & .02 & $<.20$ & .56 & .35 & 15 \\
\hline 4N/18W-31D6 & $04-06-95$ & .84 & $<.015$ & $<.20$ & .08 & .09 & 23 \\
\hline 4N/18W-31D6 & $09-17-96$ & 2 & $<.015$ & $<.20$ & .04 & .07 & 23 \\
\hline 4N/18W-31D7 & $06-25-94$ & 2 & .02 & $<.20$ & 1.80 & .81 & 16 \\
\hline $4 \mathrm{~N} / 18 \mathrm{~W}-31 \mathrm{D} 7$ & $04-06-95$ & .84 & $<.015$ & $<.20$ & .27 & .26 & 28 \\
\hline 4N/18W-31D7 & $09-17-96$ & .46 & .03 & $<.20$ & .08 & .12 & 35 \\
\hline
\end{tabular}




\begin{tabular}{|c|c|c|c|c|c|c|c|}
\hline State well No. & Date & $\begin{array}{l}\text { Boron, } \\
\text { dissolved, } \\
\text { ( } \mu g / \text { as B) }\end{array}$ & $\begin{array}{c}\text { Iron, } \\
\text { dissolved } \\
\text { ( } \mu \mathrm{g} \Omega \text { as Fe })\end{array}$ & $\begin{array}{c}\text { Mange- } \\
\text { nese, } \\
\text { dissolved } \\
(\mu g / \text { as } \\
\text { Mn })\end{array}$ & $\begin{array}{l}\text { Strontium, } \\
\text { dissolved } \\
(\mu g / \text { as Sr) }\end{array}$ & $\begin{array}{c}H^{2} \mathbf{H}^{1} \\
\text { (per mll) }\end{array}$ & $\begin{array}{l}\mathrm{O}^{18} / \mathrm{O}^{16} \\
\text { (per mil) }\end{array}$ \\
\hline $3 \mathrm{~N} / 21 \mathrm{~W}-15 \mathrm{G}-\mathrm{CORE}$ & $04-30-94$ & - & $\overline{-}$ & - & - & -50.80 & -7.29 \\
\hline $3 \mathrm{~N} / 21 \mathrm{~W}-15 \mathrm{G} 1$ & $06-14-94$ & 520 & $<3.0$ & 470 & 1,000 & -54.10 & -7.84 \\
\hline $3 \mathrm{~N} / 21 \mathrm{~W}-15 \mathrm{G} 1$ & 04-03-95 & 550 & $<3.0$ & 450 & 1,000 & - & - \\
\hline $3 \mathrm{~N} / 21 \mathrm{~W}-15 \mathrm{G} 1$ & $09-06-96$ & 486 & $<3.0$ & 430 & 960 & - & - \\
\hline $3 \mathrm{~N} / 21 \mathrm{~W}-15 \mathrm{G} 2$ & $06-14-94$ & 580 & $<3.0$ & 510 & 1,100 & -53.80 & -7.86 \\
\hline $3 \mathrm{~N} / 21 \mathrm{~W}-15 \mathrm{G} 2$ & 04-03-95 & 610 & $<3.0$ & 560 & 1,100 & - & - \\
\hline $3 N / 21 W-15 G 2$ & $09-06-96$ & 535 & $<3.0$ & 540 & 1,000 & - & - \\
\hline $3 \mathrm{~N} / 21 \mathrm{~W}-15 \mathrm{G} 3$ & $06-15-94$ & 540 & $<3.0$ & 250 & 970 & -52.90 & -7.67 \\
\hline $3 \mathrm{~N} / 21 \mathrm{~W}-15 \mathrm{G} 3$ & 04-04-95 & 530 & $<3.0$ & 260 & 960 & - & - \\
\hline $3 N / 21 W-15 G 3$ & $09-06-96$ & 488 & $<3.0$ & 260 & 900 & - & - \\
\hline $3 \mathrm{~N} / 21 \mathrm{~W}-15 \mathrm{G} 4$ & $06-15-94$ & 590 & 530 & 550 & 1,100 & -51.00 & -7.53 \\
\hline $3 \mathrm{~N} / 21 \mathrm{~W}-15 \mathrm{G} 4$ & $04-30-94$ & 580 & $<3.0$ & 510 & 1,100 & - & - \\
\hline 3N/21W-15G4 & $09-06-96$ & 568 & $<3.0$ & 570 & 1,100 & - & - \\
\hline $3 \mathrm{~N} / 21 \mathrm{~W}-15 \mathrm{G} 5$ & 06-14-94 & 820 & $<3.0$ & 9 & 1,400 & -51.20 & -7.38 \\
\hline $3 N / 21 W-15 G 5$ & 04-04-95 & 770 & $<3.0$ & 10 & 1,400 & - & - \\
\hline $3 \mathrm{~N} / 21 \mathrm{~W}-15 \mathrm{G} 5$ & $09-06-96$ & 767 & $<3.0$ & 8 & 1,400 & - & - \\
\hline $3 \mathrm{~N} / 21 \mathrm{~W}-16 \mathrm{H} 5$ & $06-16-94$ & 550 & $<3.0$ & 100 & 1,100 & -48.70 & -7.39 \\
\hline $3 \mathrm{~N} / 21 \mathrm{~W}-16 \mathrm{H} 5$ & $04-05-95$ & 570 & 3 & 100 & 1,100 & - & - \\
\hline $3 \mathrm{~N} / 21 \mathrm{~W}-16 \mathrm{H} 5$ & $09-05-96$ & 494 & $<3.0$ & 97 & 1,000 & - & - \\
\hline $3 \mathrm{~N} / 21 \mathrm{~W}-16 \mathrm{H} 6$ & $06-16-94$ & 630 & 4 & 15 & 1,500 & -50.80 & -7.32 \\
\hline $3 \mathrm{~N} / 21 \mathrm{~W}-16 \mathrm{H} 6$ & $04-05-95$ & 650 & 5 & 7 & 1,500 & - & - \\
\hline $3 \mathrm{~N} / 21 \mathrm{~W}-16 \mathrm{H} 6$ & $09-05-96$ & 591 & $<3.0$ & 9 & 1,400 & - & - \\
\hline $3 \mathrm{~N} / 21 \mathrm{~W}-16 \mathrm{H} 7$ & $06-16-94$ & 760 & $<3.0$ & 50 & 1,500 & -51.90 & -7.43 \\
\hline $3 \mathrm{~N} / 21 \mathrm{~W}-16 \mathrm{H} 7$ & $04-05-95$ & 790 & $<3.0$ & 47 & 1,500 & - & - \\
\hline $3 \mathrm{~N} / 21 \mathrm{~W}-16 \mathrm{H} 7$ & 09-05-96 & 705 & $<3.0$ & 42 & 1,200 & - & - \\
\hline $3 \mathrm{~N} / 21 \mathrm{~W}-16 \mathrm{H} 8$ & $06-15-94$ & 880 & 89 & 130 & 1,300 & -49.60 & -7.21 \\
\hline $3 \mathrm{~N} / 21 \mathrm{~W}-16 \mathrm{H} 8$ & $04-05-95$ & 1,200 & 250 & 280 & 1,600 & - & - \\
\hline $3 \mathrm{~N} / 21 \mathrm{~W}-16 \mathrm{H} 8$ & $09-05-96$ & 1,110 & 320 & 270 & 1,500 & - & - \\
\hline 4N/18W-31D3 & $06-25-94$ & 770 & $<3.0$ & 4 & 920 & -62.00 & -8.84 \\
\hline 4N/18W-31D3 & $04-06-95$ & 700 & $<3.0$ & $<1.0$ & 1,000 & -60.70 & -8.74 \\
\hline 4N/18W-31D3 & $09-17-96$ & 672 & $<3.0$ & $<1.0$ & 1,100 & - & - \\
\hline 4N/18W-31D4 & $06-25-94$ & 620 & 9 & 11 & 1,100 & -49.80 & -6.91 \\
\hline 4N/18W-31D4 & 04-06-95 & 600 & $<3.0$ & 1 & 1,200 & -50.50 & -6.96 \\
\hline 4N/18W-31D4 & $09-17-96$ & 569 & $<3.0$ & $<1.0$ & 1,200 & - & - \\
\hline 4N/18W-31D5 & $06-25-94$ & 600 & $<3.0$ & 2 & 800 & -57.30 & -7.86 \\
\hline 4N/18W-31D5 & $04-06-95$ & 590 & $<3.0$ & $<1.0$ & 860 & -57.30 & -7.79 \\
\hline 4N/18W-31D5 & $09-17-96$ & 459 & $<3.0$ & $<1.0$ & 1,000 & - & - \\
\hline 4N/18W-31D6 & $06-25-94$ & 450 & 5 & 2 & 950 & -54.80 & -7.80 \\
\hline 4N/18W-31D6 & $04-06-95$ & 470 & $<3.0$ & $<1.0$ & 1,000 & -54.50 & -7.55 \\
\hline 4N/18W-31D6 & $09-17-96$ & 500 & $<3.0$ & $<1.0$ & 1,000 & - & - \\
\hline 4N/18W-31D7 & $06-25-94$ & 500 & 13 & 10 & 920 & -56.10 & -7.90 \\
\hline $4 \mathrm{~N} / 18 \mathrm{~W}-31 \mathrm{D} 7$ & 04-06-95 & $510^{\circ}$ & $<3.0$ & $<1.0$ & 990 & -55.10 & -7.82 \\
\hline 4N/18W-31D7 & $09-17-96$ & 496 & $<3.0$ & 16 & 1,000 & - & - \\
\hline
\end{tabular}




\begin{tabular}{|c|c|c|c|c|c|c|}
\hline State well No. & Date & $\begin{array}{l}\text { Tritlum, in } \\
\text { water mole- } \\
\text { cules (TU) }\end{array}$ & $\begin{array}{l}\text { Tritium } \\
\text { counts } \\
\text { error (TU) }\end{array}$ & $\begin{array}{l}\text { Carbon 13/ } \\
12 \text { (per mll) }\end{array}$ & $\begin{array}{l}\text { Carbon-14 } \\
\text { (percent mod- } \\
\text { ern) }\end{array}$ & $\begin{array}{c}\text { Strontlum } \\
87 / 86 \text { (ratio) }\end{array}$ \\
\hline $3 \mathrm{~N} / 21 \mathrm{~W}-15 \mathrm{G}-\mathrm{CORE}$ & $04-30-94$ & - & - & - & - & 0.70956 \\
\hline $3 \mathrm{~N} / 21 \mathrm{~W}-15 \mathrm{G} 1$ & $06-14-94$ & .1 & .2 & -13.4 & 54.3 & - \\
\hline $3 \mathrm{~N} / 21 \mathrm{~W}-15 \mathrm{G} 1$ & 04-03-95 & - & - & - & - & - \\
\hline $3 \mathrm{~N} / 21 \mathrm{~W}-15 \mathrm{G} 1$ & $09-06-96$ & - & 一 & - & - & - \\
\hline $3 \mathrm{~N} / 21 \mathrm{~W}-15 \mathrm{G} 2$ & $06-14-94$ & .6 & .2 & - & - & - \\
\hline $3 \mathrm{~N} / 21 \mathrm{~W}-15 \mathrm{G} 2$ & 04-03-95 & - & - & - & - & - \\
\hline $3 \mathrm{~N} / 21 \mathrm{~W}-15 \mathrm{G} 2$ & 09-06-96 & - & - & - & - & - \\
\hline $3 \mathrm{~N} / 21 \mathrm{~W}-15 \mathrm{G} 3$ & $06-15-94$ & .3 & .2 & - & - & - \\
\hline $3 \mathrm{~N} / 21 \mathrm{~W}-15 \mathrm{G} 3$ & $04-04-95$ & - & - & - & - & - \\
\hline $3 N / 21 W-15 G 3$ & 09-06-96 & - & - & - & - & - \\
\hline $3 \mathrm{~N} / 21 \mathrm{~W}-15 \mathrm{G} 4$ & $06-15-94$ & 2.2 & .2 & - & - & - \\
\hline $3 N / 21 W-15 G 4$ & $04-30-94$ & - & - & - & - & - \\
\hline 3N/21W-15G4 & $09-06-96$ & - & - & - & - & - \\
\hline $3 \mathrm{~N} / 21 \mathrm{~W}-15 \mathrm{G} 5$ & $06-14-94$ & 4.7 & .3 & - & - & - \\
\hline $3 N / 21 W-15 G 5$ & $04-04-95$ & - & - & - & - & - \\
\hline $3 \mathrm{~N} / 21 \mathrm{~W}-15 \mathrm{G} 5$ & 09-06-96 & - & - & - & - & - \\
\hline $3 \mathrm{~N} / 21 \mathrm{~W}-16 \mathrm{H} 5$ & $06-16-94$ & 1.8 & .2 & -13.1 & 53.4 & - \\
\hline $3 \mathrm{~N} / 21 \mathrm{~W}-16 \mathrm{H} 5$ & $04-05-95$ & - & - & - & - & - \\
\hline $3 \mathrm{~N} / 21 \mathrm{~W}-16 \mathrm{H} 5$ & 09-05-96 & - & - & - & - & - \\
\hline $3 \mathrm{~N} / 21 \mathrm{~W}-16 \mathrm{H} 6$ & 06-16-94 & 4.7 & .3 & - & - & - \\
\hline $3 \mathrm{~N} / 21 \mathrm{~W}-16 \mathrm{H} 6$ & $04-05-95$ & - & - & - & - & - \\
\hline $3 \mathrm{~N} / 21 \mathrm{~W}-16 \mathrm{H} 6$ & $09-05-96$ & - & - & - & - & - \\
\hline $3 \mathrm{~N} / 21 \mathrm{~W}-16 \mathrm{H} 7$ & $06-16-94$ & 5.6 & .4 & - & - & - \\
\hline $3 \mathrm{~N} / 21 \mathrm{~W}-16 \mathrm{H} 7$ & 04-05-95 & - & - & - & - & - \\
\hline $3 \mathrm{~N} / 21 \mathrm{~W}-16 \mathrm{H} 7$ & $09-05-96$ & - & - & - & - & - \\
\hline $3 \mathrm{~N} / 21 \mathrm{~W}-16 \mathrm{H} 8$ & $06-15-94$ & 5.3 & .3 & - & - & - \\
\hline $3 \mathrm{~N} / 21 \mathrm{~W}-16 \mathrm{H} 8$ & 04-05-95 & - & - & - & - & - \\
\hline $3 \mathrm{~N} / 21 \mathrm{~W}-16 \mathrm{H} 8$ & 09-05-96 & - & - & - & - & - \\
\hline 4N/18W-31D3 & $06-25-94$ & .2 & .2 & - & - & - \\
\hline 4N/18W-31D3 & 04-06-95 & & & -.8 & 76.9 & - \\
\hline 4N/18W-31D3 & $09-17-96$ & - & - & - & - & - \\
\hline 4N/18W-31D4 & $06-25-94$ & 6.3 & .4 & - & - & - \\
\hline 4N/18W-31D4 & $04-06-95$ & - & - & - & - & - \\
\hline 4N/18W-31D4 & $09-17-96$ & - & - & - & - & - \\
\hline 4N/18W-31D5 & $06-25-94$ & 5.0 & .3 & - & - & - \\
\hline 4N/18W-31D5 & $04-06-95$ & - & - & - & - & - \\
\hline 4N/18W-31D5 & $09-17-96$ & - & - & - & - & - \\
\hline 4N/18W-31D6 & $06-25-94$ & 4.7 & .3 & - & - & - \\
\hline 4N/18W-31D6 & $04-06-95$ & - & - & - & - & - \\
\hline 4N/18W-31D6 & $09-17-96$ & - & - & - & - & - \\
\hline 4N/18W-31D7 & $06-25-94$ & 4.4 & .3 & - & - & - \\
\hline 4N/18W-31D7 & 04-06-95 & - & - & - & - & - \\
\hline 4N/18W-31D7 & 09-17-96 & - & - & - & - & - \\
\hline
\end{tabular}


Appendix 5. Depths and perforated intervals for non-USGS monitoring wells, Ventura County, California

[ft below lsd, feet below land-surface datum; - , no data]

\begin{tabular}{|c|c|c|}
\hline State well No. & $\begin{array}{l}\text { Well depth } \\
\text { (ft below Isd) }\end{array}$ & $\begin{array}{c}\text { Perforated } \\
\text { Interval } \\
\text { (ft below Isd) }\end{array}$ \\
\hline $3 \mathrm{~N} / 19 \mathrm{~W}-6 \mathrm{D} 3$ & 400 & $184-400$ \\
\hline $3 \mathrm{~N} / 20 \mathrm{~W} 2 \mathrm{Al}$ & 92 & - \\
\hline $3 \mathrm{~N} / 20 \mathrm{~W}-3 \mathrm{~N} 1$ & 184 & $120-172$ \\
\hline 3N/20W-6P2 & 252 & - \\
\hline 3N/21W-11D2 & 570 & $232-543$ \\
\hline $3 \mathrm{~N} / 21 \mathrm{~W}-12 \mathrm{~F} 3$ & 300 & $120-284$ \\
\hline $3 \mathrm{~N} / 21 \mathrm{~W}-12 \mathrm{H} 1$ & 158 & $74-150$ \\
\hline $3 \mathrm{~N} / 21 \mathrm{~W}-15 \mathrm{C} 4$ & 284 & - \\
\hline $3 \mathrm{~N} / 21 \mathrm{~W}-15 \mathrm{C} 6$ & 670 & $452-673$ \\
\hline $3 \mathrm{~N} / 21 \mathrm{~W}-16 \mathrm{~A} 2$ & 600 & $430-580$ \\
\hline $3 \mathrm{~N} / 21 \mathrm{~W}-16 \mathrm{~K} 1$ & 216 & $105-210$ \\
\hline $3 \mathrm{~N} / 21 \mathrm{~W}-16 \mathrm{~K} 3$ & 795 & $672-760$ \\
\hline $3 \mathrm{~N} / 21 \mathrm{~W}-19 \mathrm{G} 4$ & 794 & $450-720$ \\
\hline $3 \mathrm{~N} / 21 \mathrm{~W}-30 \mathrm{H} 4$ & 500 & $100-400$ \\
\hline $3 \mathrm{~N} / 21 \mathrm{~W}-34 \mathrm{~A} 1$ & 150 & - \\
\hline $3 N / 22 W-36 K 4$ & 871 & $699-867$ \\
\hline $3 N / 22 W-36 R 1$ & 250 & $100-250$ \\
\hline $4 \mathrm{~N} / 18 \mathrm{~W}-20 \mathrm{M} 1$ & 397 & - \\
\hline $4 \mathrm{~N} / 18 \mathrm{~W}-20 \mathrm{~N} 1$ & 441 & - \\
\hline $4 \mathrm{~N} / 18 \mathrm{~W}-20 \mathrm{P} 1$ & 100 & - \\
\hline $4 N / 18 W-28 C 2$ & 750 & $390-750$ \\
\hline $4 \mathrm{~N} / 18 \mathrm{~W}-29 \mathrm{~F} 1$ & 285 & - \\
\hline $4 \mathrm{~N} / 18 \mathrm{~W}-29 \mathrm{~K} 1$ & 745 & $465-745$ \\
\hline 4N18W-29M2 & 142 & - \\
\hline 4N18W-31D2 & 500 & $220-500$ \\
\hline $4 \mathrm{~N} 19 \mathrm{~W}-25 \mathrm{~J} 4$ & 500 & - \\
\hline 4N19W-26Q3 & - & - \\
\hline $4 \mathrm{~N} 19 \mathrm{~W}-27 \mathrm{R} 3$ & 402 & $240-402$ \\
\hline 4N19W-29R4 & 180 & $80-180$ \\
\hline 4N19W-30Q2 & 510 & $310-510$ \\
\hline 4N19W-30R1 & 305 & $173-300$ \\
\hline 4N19W-34R1 & - & - \\
\hline 4N19W-35L5 & 302 & - \\
\hline 4N19W-06D3 & 400 & $184-400$ \\
\hline $4 \mathrm{~N} 20 \mathrm{~W}-24 \mathrm{R} 2$ & 2,018 & $730-1,820$ \\
\hline $4 \mathrm{~N} 20 \mathrm{~W}-25 \mathrm{~B} 1$ & 300 & $50-280$ \\
\hline $4 \mathrm{~N} 20 \mathrm{~W}-26 \mathrm{~L} 1$ & 397 & $100-397$ \\
\hline $4 \mathrm{~N} 20 \mathrm{~W}-32 \mathrm{R} 1$ & 334 & - \\
\hline $4 \mathrm{~N} 20 \mathrm{~W}-33 \mathrm{C} 3$ & 724 & $470-700$ \\
\hline
\end{tabular}


